[evision.] PRICE ONE SHIIIING.

708.2
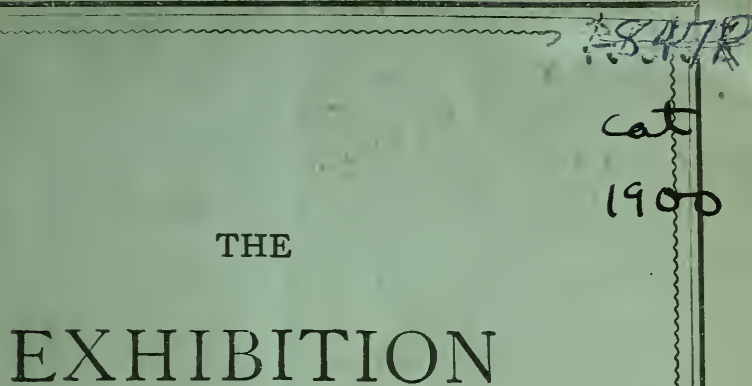

OF THE

\title{
ROYAL ACADEMY OF ARTS
}

MDCCCC.

THE ONE HUNDRED AND THIRTY-SECOND.

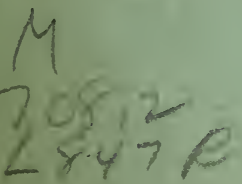

WM. CLOWES AND SONS, LIMITEI, PRINTERS TO THE ROYAL ACADEMY. 
The Exhibition opens the first Monday in May, and closes first Monday in August.

Hours of Admission from 8 a.m. till 7 p.m. (except on the firs day, when the doors do not open before ro a.m.). Hour of Closing, 7.30 p.m.

Price of Admission, Is.

Price of Catalogue : Large, with paper cover, Is. Small, with paper cover, Is. ; Small, bound in cloth, with pencil, Is. 6d.

Season Ticket, 5 s.

Visitors are not required to give up their sticks, umbrellas, or parasols before entering the Galleries; but they can leave them, if they wish, with the attendants at the Cloak Room, in the Entrance Hall. The other attendants are strictly forbidden to take charge of anything.

The Refreshment Room is reached by a staircase leading out of the Water Colour Room.

Catalogues can only be obtained at the Academy. All applications for Catalogues to be sent by post must be addressed to "The Secretary," and be accompanied by Is. $I \frac{1}{2} \mathrm{~d}$. in stamps for a paper-covered copy, and Is. 8d. for a bound copy.

All communications should be addressed to "The Secretary," and not to any official by name.

The Gibson (Sculpture) Gallery and the Diploma Galleries are ofen danly, from II a.m. to 4 p.m. Admission fres. 


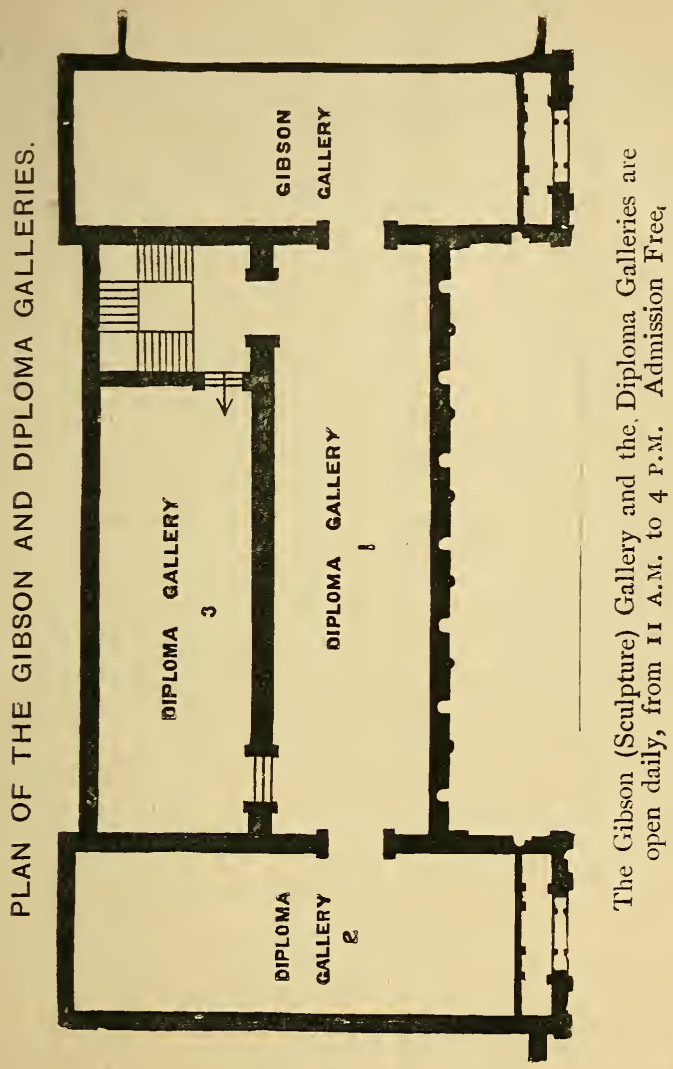




\section{ROYAL ACADENY OF ARTS IN LONDON,}

\section{HONURARY MEMBERS.}

The Most Rey. W. D. Maclagan, J). I., Lorn Archbisiop of York, Chryplain.

Professor R. C. JeBb, M.P., Professor of Ancient History.

The Rt. Rev. M. Creighton, D.D., Lond Bisilop of Loxnon, Professor of Ancient Literature Francis C. Pexrose, Esq., F.IR.S., Antiquary.

The Rt. Hon. Willia E. H. LEcky, M.P., Secretary for Foreign Correspondence.

\section{HONORARY RETIRED ACADEMICIANS.}

Faed, Thomas, Esq.

Frith, Willas Powell, Es?.

Horsley, JohN Calcott, Esq.
Pickersgill, Frenk. Rich., Ese.

WATtS, GEORge Frederick, Ese.

\section{HUNORART FOREIGN ACADEMICIANS.}

Breton, Jlles.

ITtroIs, Pale.

GEROME, JeANiLíoN.
Gerllalme, Clatde J. B. E.

Knals, Ledwig.

IIENZEL, ADOLF.

\section{ACADEMICIANS.}

A bBes, Edwis Austin, Esq.

Aitchisos, George, Ese.

Alma-Tadema, Sir Lawrexce.

A rustead, Hexry Hegh, Esq.

Botghtos, George H., Eso.

Brock, THomas, Esq.

Cooper, Thomas Sidxey, Esq.

Crofts, EnNest, Eso., Keeper and Trustee.

Javis, Hexry Wy. Banks, Esq.

IICKSEE, FRANK, EsQ., A uditor.

Fildes. Letie, Eso.

Ford, EDWARD ONSLow, Ese.

GILBERT, AlFRED, EsQ., M.V.o.

Goodall, Frederick, EsQ.

Gow, AXDREW C., EsQ.

Grailay, Peter, Esq.

('REGORT, EDWARD JoHN, Esq.

HerkoMer, HeBERT YoN. Es?.

Hook, Jayes Clarke, Ese.

Jackson, Thomas Grahay, Esq., Auditor.

Leader, Bexjayix Williays, Esq.
Leshe, George Dexlop, Esq.

LTCAS, JOHN SEYMOLR, ESQ.

M acWhirter, Johs, Eso.

ORCHARDSON, WILLIAM QCILLER, Esq.

O'Less, WaLter Willas, EsQ.

Porster, SIR EDTARD J., President anl Trustee.

Prinsep, Valextine Cayeron, Eso.

RichyoNd, SiR WiLliaM BLAKE, K.C.B.

Riviere, Britos, Esq., Trustee.

Sant, Jasis, Esq.

SARGEXT, JoHX Sixger, Esq.

Shaw, Richard Normax, Esq.

StoNe, M ARces, Es?.

THORNYCROFT, W. HaMo, EsQ.

W ATERHocse, Alfred, Esq., Treasurer and Trustee.

Waterhorse, Johx Willias, Esq.

Whils, HeNRY TANWORTH, EsQ., Auditor.

WOODS, HENRT, EsQ.

YEAMES, WM. FrEDK., EsQ., Librarian.

\section{HONORARY RETIRED ASSOCIATES.}

\section{Le Jelse, Henry. I Nicol, Erskine. \\ ASSOCIATES.}

BELCHER, JoHN.

Bodlex, George Frederick.

Brayley, Frank.

BRETT, JohN.

Clat'sex, Grorge.

Cope, Arthl一 Stockdale.

Crowe, ETre.

I RCRY, Edw. Alfred Briscoe.

EAST, AI.FRED.

Forbes, Stanhope A.
Frampton, Geor e Jajes.

Hacker, Arther.

Heay, Charles Napier.

Huster, Colis.

Johs, Willia goscombe.

La Thangue, Hexiry Her hert.

M acbeth, Robert Walker.

Morris, Philip Richard.

Mtrray, David.

NoRTh, JoHs Williay.
Stacpoole, Frederic.

\section{PROFESSORS.}

Of Painting, vacant.

Jf Sculpture, racant.

of Architecture, GEORge Aitcuison, Es\&., R.A.
Of Anatomy. Williay Axdersos, F.R.C.S.

Of Chemistry, ARTHCR Herbert CHLRCH, M.A., F.R.S.
PARsons, Alfred.

SHANNON, JAMES J.

Syythe, Liosel Percy.

Solomox, Solomos J.

STOREY, GEORGE A DOIPHCS.

Swax, Johy MacAllas.

Teke, Hexry Scotr.

WATERlow, ERNest Albert.

WEBH, Astox.

Wrllie, Williay Liosel.

Teacher of Perspective, racant.

Master of the Architectural School, R. Phené Spiers.

\section{SECRETAR Y.}

Fren. A. Faton. 


\section{THE}

\section{EXHIBITION OF THE}

\section{ROYAL ACADEMY OF} MDCCCC.

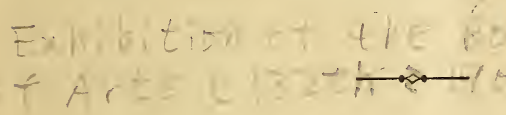

\section{ACI I
LIBRARIES}

THE ONE HUNDRED AND THIRTY-SECOND.

"It is only the disease of the unskilful to think rude things greater than polished."-Ben fonson.

\section{LONDON :}

PRINTED BY WM. CLOWES AND SONS, LIMITED,

I4 CHARING CROSS,

PRINTERS TO THE ROYAL ACADEMY.

[Entered at Stationers' Hall.] 


\section{CONTENTS.}

\section{Oil Paintings.}

PAGE

Gallery I.-(Nos. I-65) . 7

, II.-(Nos. 66-I36) I I

,, III.-(Nos. I37-233) I6

, IV.-(Nos. 234-3IS) 22

, V.-(Nos. 319-393) 27

, VI.-(Nos. 394-522) 3 I

,, VII.-(Nos. 523-6Io) 37

,, VIII.-(Nos. 6I I-685) 42

, IX.-(Nos. 686-942) 47

, X.-(Nos. 943-1020) 58

,, XI.-(Nos. IO2I-IOgo) 63

\section{Water Colours.}

Water Colour RoOM-

(Nos. IOgI-I355) $\ldots \quad \ldots 67$

\section{Enamels.}

WATER COLOUR ROOM- (Nos. 1356--136I) . . . So
Miniatures. IVAGF Water Colour RoOM(Nos. I362-I526) $\ldots \quad \ldots 8$ I Etchings, Drawings, and Engravings.

Black and White Room(Nos 1 527-1679) . . . . 89

\section{Architectural Drawings.}

ARchiteci URal RoON -

(Nos. 1680-1912) $\ldots \quad \ldots 97$

\section{Sculpture.}

Central Hall - (Nos. I9I3-I939) $\ldots$. . . . II3 LECTURE ROOM - (Nos. I940-2056) . . . . . I I I5 IN THE QUADRANGIE$\begin{array}{lllll}(N o .2057) & \ldots & \ldots & \text {. } & 122\end{array}$ 


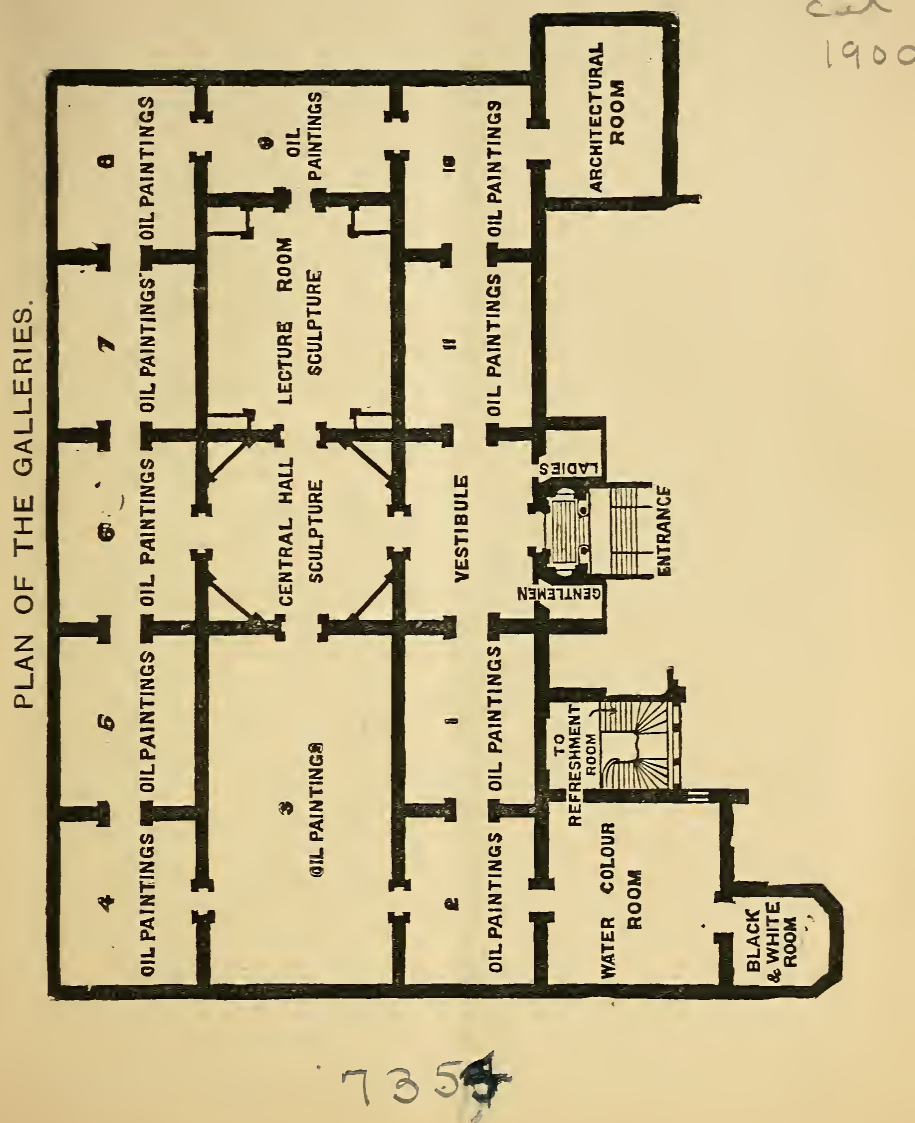




\section{NOTICE TO EXHIBITORS.}

(1.) TiME For, AND Mode of, SExDixg ix Works.-All Works intended for the Annual Exhibition at the Royal Academy, MUST BE PUNCTUALLY SENT THERE ON ONE OF THE DAYS FIXED FOR THEIR RECEPTION. No Works will under any cireumstances be received after the specified dates.

All Works sent from the country or from abroad must be consigned to an Agent in London for delivery at the Academy, unpacked, on one of the appointed days. No Works in cases will be received; nor will the expenses of carriage be defrayed by the Academy. The attention of Foreign Artists and of English Artists residing in the country and abroad is esivecially called to this regulation.

(2.) MoDe of DEscribixg Works. - All Works must be accompanied with a printed form duly filled in with the Name (Christian and Surname in full, signed by the Artist) and Address of the Artist, the Titles and Descriptions of the Works as they are to be inserted in the Catalogue, and the Price if it is desired to place them on sale. These forms must he sent under cover addressed to "The Secretary," and be delivered with the Works. No advertisement, unnecessary quotation, or narrative can be admitted.

it the back of each frame must be written the Name and Address of the Artist, with the Title or Deseription of the Picture, and the Number (if there be more than one) to which it refers in his List. This information must also be repeated, with great distinctness and accuracy, on a label attached by a string to the top of each frame, and made to hang over in front, as also to each piece of Sculpture.

It is necessary that these Regulations, more especially the last, should be strictly complied with, in order to avoid delay and inconvenience as well as inaccuracy in the Catalogue.

The Forms and Labels can be procured (during the month of March only) from the Academy on receipt of a stamped and directed envelope.

(3.) NCMPER of Works Allowed.-No Artist is allowed to send or exhibit more than Eight different Works.

(4.) Size of Frames, Margins, \&c.-Each Picture, or Drawing, must be in a separate Frame, or, if a series of Drawings from one Story be at any time admitted in the same Frame, they must be enumerated as distinct pieces. A case of Miniatures or Sculptured Gems will be considered as one Work, provided the size of the case'does not exceed six inches by fire inches; and a case of Medals or Plaques, each of which is not more than seren inches in its widest dimensions, will be considered as one Work, provided the size of the case does not exceed three feet by four feet.

All Pictures and Drawings must be in Gilt Frames. OIL PAINTINGS CNDER GLASARE INAIMISSIBLE. EXCESSIVE BREADTH IN FRAMES OR MARGINS AS WELL AS PRO.TETING MOULDINGS, MAY PREVENT PICTURES AND DRAWINGS OBTAIXIXG THE SITUATION THEY OTHERWISE MERIT. Oval Frames should be avoided, as they are difticult of arrangement. Low-reliefs should be framed.

(5.) Works INADMissible.-No Works which have been already publicly exhibited in London:- no copies of any kind (excepting Paintings in Enamel, and Impressions from unpublished Medals, in which ease the name of the original Designer must be specified); -no mere Transeripts of the objects of Natural History;-no Vignette Portraits, nor any Irawings without Backgrounds (excepting Architectural Designs); -and no Engravings or Etchings that have been published six months can be received.

(6.) SELECTIO: of Works.-All Works sent for exhibition are submitted to the judgment of the Council, whose decision is final, and is officially communicated by letter to every contributer.

(7.) SALE of Works. - The Prices of Works to be disposed of may be communicated to "The Secretary," and will be entered in the Price Catalogues placed in one of the Galleries. Communications with regard to the Price and Sale of Works must in all cases be made by the Artist, and be addressed in writing to "The Secretary." All purchases will he recistered, but the Academy can undertake no responsibility with regard to either the payment for the Works purchased, or for their delivery to the purchaser.

(8.)-Close of THE Exhibition.-Delivery of Works. - Before the closing of the Exhibition every Exhibitor will receive a separate Printed Order for the Delivery of each of his Works. These must be properly filled in and signed by the Artist, and presented by the person sent to claim the Work, who must sign a receipt for it in a book provided for the purpose. No Work will be delivered up without the production of the Order. The Academs will not undertake to pack or forward any Work.

All Works must be removed within ten days from the closing of the Exhibition.

(9.) Privileges of Exhibitors. - Each Exhibitor is entitled to a Ticket of Admission to the Exhibition, as also to the ensuing Winter Lectures and Winter Exhibition of Old Masters. They can only be obtained by personal application at the Royal Academy.

When Works are described as the joint performance of several Artists, the first mentiontal in the rescription will alone be entitled to the above Tickets.

** EVERY POSSIBLE CARE WILL BE TAKEN OF WORKS SENT FOR ENHI. BITION; BUT THE ROYAL ACADEMY WILL NOT HOLD ITSELF ACCOCNTAELE IY ANY' CASE OF INJURY OR LOSS. 


\section{CATA LOGUE.}

The Prices of Works may be ascertained at the tables in the Vestibule.

(See paragraphs 7 and 8 in the "Notice to Exhibitors.")

The Numters of the Works follow from Left to Right, the first Number being next the Door.

R.A. Royal Academician. A. Associate.

\section{GALLERY No. I. \\ OIL PAIN'TINGS-(Nos. 1-65).}

I-Moorland : Poolewe, Ross-shire.. W. Paterson.

2-Mrs. C. Goldsborough Anderson

C. Goldsborough Anderson.

3-Ix the Meadows: Youngsbury Alfred A. Glendening. 4-Setting up Sheaves .. .. . . George Clausen, A

5-A Lute-Player. Diploma work, deposited on his election as an Academician $\quad \ldots \quad \ldots \quad \ldots$.. E. A. Abbey, R.A.

6-The Old Bridge... .. .. Stanhope A. Forbes, A.

7-EARly Morning: signal for a pilot off Guernsey .. .. .. Edwin Hayes. S-November $\quad \ldots \quad \ldots \quad \ldots \quad$. . Mariquita J. Moberly. 
9-On the Griffe: Bridge of Weir

Norman M. Macdongall.

IO-Ringing the Angelus: Roncon

Church, Normandy .. .. .. Harry Scully'.

i i-Portrait of a Lady $\ldots$.. $\quad . . \quad T$. C. Gotch.

i2-The Land of Olives .. .. Emest A. Waterlow, A.

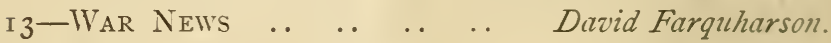

i4-The City of Durhali .. .. Niels M. Lund.

i5-Lady Aristrong .. .. Hubert von Herkomer, R.A. i6-After Sunset .. . . . H. W. B. Davis, R.A. i 7-Miss Lawrence Alma-Tadema .. Hon. John Collier. i8-Toil and Pleasure .. .. .. Edmund G. Fuller. I9-Daisy, daughter of Edwin Tate,

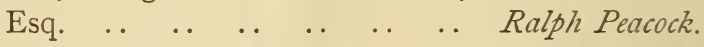

20-Over the Sea from Skye.. J. MaclWhirter, R.A. 2 I_-"Thanks, Awfully" .. . . . Alfred W. Strutt. 22-A Love-Song ....$\quad$.. . . Nina Hardy. 23-Checkmate .. .. .. .. .. Fred Roe. 24-Cinderella - a portrait .. .. John H. F. Bacon.

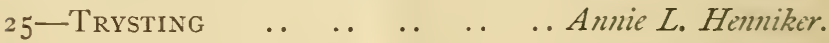
26-A Morning Drink .. .. .. Arthur Ilardle. 27-A Path Through Trees .. ..Gerald Ackermann. 28-The Love-Letter _. .. G. Sheridan Knoziles. 29-Wandering Thoughts A $\quad$. $\quad$ F. D. Millet. 30-Martin J. Sutton, EsQ. Presentation Portrait .. . . Henry T. Wells, R.A. 3i-Mrs. Tom Craven . . . . . Luke Fildes, R.A. 
32-Charles II. and Nell Gwynne Rowuland Holyoake. "When he was dumpish, she would still be jocund, And chuck the Royal chin of Charles the Second."

- Sir George Etheridge.

33-The Pear-Orchard .. .. . . John B. Noel. 34-Fallex Majesty .. .. .. .. Winifred Austen.

35-A HAY-DaY .. ..

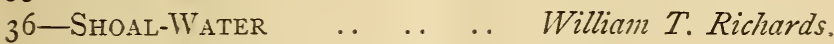

37-The Keeper of the King'S

Conscience $\quad$. . $\quad$. $\quad$.. $\quad$ Seymour Lucas, R.A.

38-Coaxing..

39-ON the Moors ..

40-The Top of the Hill .. .. John C. Dollman.

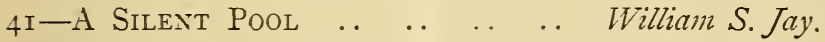

42-The Flush of Dying Dai .. V. P. Yglesias.

43-The Grees Punt .. .. .. Alfred Parsons, A.

44-The Earl of Dalhousie. Pre-

sentation Portrait .. .. John S. Sargent, R.A.

45-Fir-Trees : Engstelen Alps, Switzer-

land

46-Near Pulborough

47-"A TEMPle Not Made With

Hand" $\quad$.

48-Ax Australian Bushman .. .. Percy F. S. Spence. 49-To Valley Pastures .. .. Peter Graham, R.A.

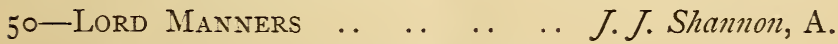
5 I-Cinderella and her Fairy GodMOTHER 
52-The Banks of the Arun .. .. Harold Goldthwait.

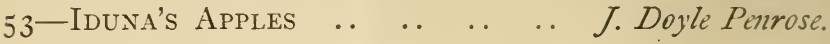

Iduna, the personification of Spring in northern mythology, possessed an unfailing casket of magic apples. These she gave to the heroes of Asgard when they came to her grove, wearied and worn out with exertions, to make them fresh and young again.

54-Brig of Balgownie .. .. .. David Murray, A.

"Brig of Balgownie, wight is thy wa"

Wi' a wife's ae son and a mare's ae foal

Down shalt thou fa'."

55-The Breeze's Kiss .. .. Lionel P. Simythe, A.

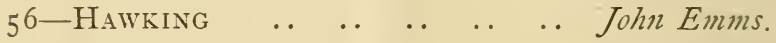

57-A Sylvan Solitude $\ldots$.. $\quad . . \quad W$. Follen Bishop. 58-A Quiet Nook: Derwentwater .. Duncan Cameron. 59-Dorothy, daughter of the artist .. Arthur W. Turner. 6o-Under Roborough Down .. .. J. L. Pickering. 6I-GRey and Gold .. 62-"I COULD NOT LOVE THEE, DEAR, SO MUCH, LOVED I NOT HONOUR MORE".. $\quad . . \quad$.. $\quad . . \quad$.. Seymour Lucas, R.A.

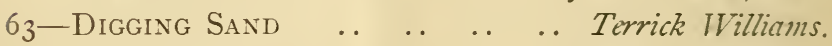

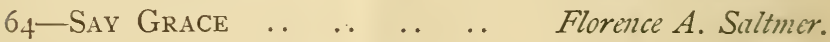
65-Autumn's Glow .. $\quad . . \quad \ldots \quad \ldots \quad R$. Scott Temple. 


\section{GALLERY No. II.}

OIL PAINTINGS-(Nos, 66-136).

66-Staithes Lights .. . . . . . . Harold Kinight. 67 -A Negro $\quad . \quad \ldots \quad \ldots \quad \ldots \quad \ldots \quad$ William Kneen. 68-Margaret Frances Greaves H. H. La Thangue, A. 69-The Heron .. .. . . . . Briton Riviere, R.A. 70-The Lady St. Levan .. .. George C. Wilmshurst 7 I-The Harvest Moon Lit by the Setting Sun $\quad \ldots \quad \ldots \quad \ldots \quad \ldots \quad$ A. E. Bailey. 72-The InN By the SeA... .. .. E. F. Brewtnall. 73-"I CANNA MIND MY WHEEL,

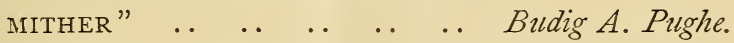
74-The Last of the Blosson .. Val Davis. 75-Portrait of a Lady .. .. I. Campbell Taylor. 76-The Palmist: a scene in Venice in the I8th century . . . . . W William Logsdail.

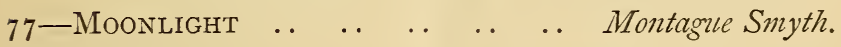
78-Solicitude $\quad . \quad \ldots \quad \ldots \quad \ldots \quad \ldots$ George F. Loosely. 79-HARD PRESSED : an incident in a run with the South Notts hounds Charles E. Baldock. 
80-Joyce, daughter of the late Hanson

Dodwell, Esq. .. $\quad$.. $\quad$.. $\quad$.. Ethel Mortlock.

8i-Andrew Carnegie, Esq. .. W. W. Ouless, R.A.

82-Oliver Cromwell at the Storm-

Ing of Basing House .. .. Ernest Crofts, R.A.

"I thank God I can give a good account of Basing House. We stormed this morning: the signal for falling-on was the firing four of our cannon; which being done, our men fell-on with great resolution and cheerfulness."- Extract from Cromwell's letter to the Speaker of the Commons, dated Basingstoke, I4th October, 1645.

83-A Pool on the Medway .. .. Ernest Parton. 84-The Hon. Guy Baring .. .. S. Melton Fisher. 85-Miss Wolf Harris .. .. .. Luke Fildes, R.A. 86-Rain in Spring .. $\quad . \quad$.. .. Alfred Parsons, A. 87-Lieut.-Colonel Rawes .. .. H. Jamyn Brooks. 88-The Guiding Hand .. $\quad . . \quad \ldots$ Charles Vigor. 89-Sanctuary in Mid Morgraunt-

from the "Forest Lovers" Frederick Beaumont. 90-The Dogs of Death .. .. .. Maud Earl.

"Beware of the White Hounds whose baying no man hears, Though it is the wind that shakes the unsteady stars : They are the Hounds seen of men in old forlorn wars : They are the Hounds that hunt the stricken years."

9i-A Willing Slave $\quad . \quad \ldots \quad \ldots$ C. E. Perugini. 92-Early Morning in the Nene VAlley $\quad$.. 
93-A Highland Trout-Stream .. Walter B. Potter. 94-Edward Rae, EsQ. Presentation

Portrait .. $\quad$.. $\quad$.. $\quad . . \quad$ Robert E. Morrison. 95-MAZEPPA 96-The Trial of Queen Katherine

Edwin A. Abbey, R.A. 97-Summer in the English West

John W. North, A.

"The pleasure of the place, the which was dight

With divers flow'rs distinct with rare delight."

98-Major Lamorock Flower .. Noel Flower.

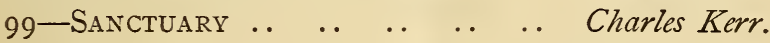

Ioo-Rose and clematis-portrait .. Phil R. Morris, A.

IOI-Hook Heath, Surrey.. .. .. Monica F. Gray.

io2-Flemish Pastures .. .. . . James L. Henry.

I03-Still-Life Group .. $\quad . . \quad$.. Wilson Jagger.

io4-The Pixies' Ring .. .. .. J. E. Christie.

105-Double Daffodils .. .. .. Alfred Morgan.

ro6-The Last Coble .. . . . Harold Knight.

io7-The Lost Labour of the

DANAIDES-typical of human

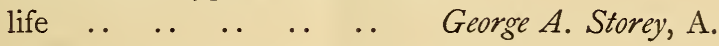

"The lost Danaides drag their endless round

In dismal Hades, there to expiate

Their nuptial crime, and fill the wasteful font

With mortal tears, alas! and there to know

The long regret, the ill no grief can mend,

The weary duty that no time can end." 
IO8-Fresh GATHERED

William Hughes. io9-Family Relics

IIO-ANChORED TO THE Nets .. . .
III-"But THINGS LIKE THIS, YOU KNOW, MUST BE IN EVERY FAMOUS

victory"

i 2-A Passing Gleam $\ldots$.. $\quad \ldots$ E. J. Du Val.

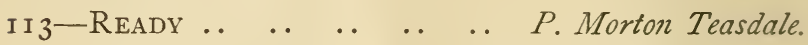

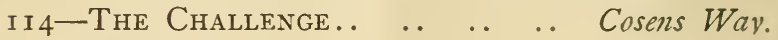

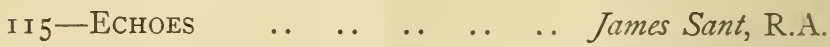

it6-A Venetian Autolycus .. Henry Woods, R.A.

i 7 -Duncan Graham, EsQ. Presentation Portrait .. $\quad$.. $\quad$.. $\quad$.. Arthur T. Nowell.

il 8-Return of the Stalker.. .. Douglas Adams.

i 9-The Lord's Prayer .. .. . . A. Dampier May.

i 20-Mists Lifting in the Glen .. H. Moxon Cook.

i 2 I-The Hon. Mrs. Portman .. J.J. Shamon, A.

I22-The Gloaming .. $\quad . \quad \ldots$, H. W. B. Davis, R.A.

I23-A Difficult Passage .. .. Agnes E. Walker.

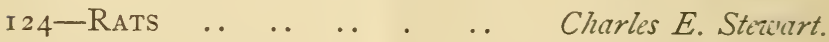

I 25-The Haunted Pool .. .. Cuthbert C. Grundy. I 26-A Marsh Road in Suffolk :

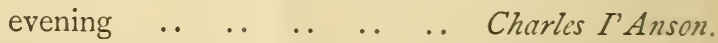
i 27-Mimosa at Mentone .. .. Evelyn P. Clark.

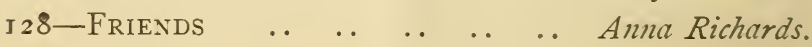


I29-Portrait of a Lady.. .. ..Frank Bramley, A. I30-RoNald, son of H. W. Henderson, Esq. .. $\quad$.. $\quad$.. $\quad$. $\quad \ldots \quad$ E. J. Gregory, R.A.

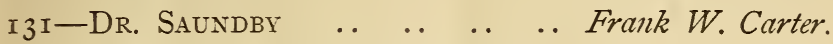
I32-A Forced Acquaintance.. .. Helen Cridland. i33-A Well in Fair Verona .. Margaret Hickson. I34-REXForD, son of C. Parsons, Esq. .. I35-Pieds D'Alouette _. .. .. H. Fantin-Latour. I36-A IVood Nymph.. .. .. Vereker M. Hamilton. 


\section{GALLERY No. III.}

\section{OIL PAINTINGS-(Nos. 137-233).}

I37-The Bridge . . . . . . . Harold Waite.

I38-ORPHEUS RETURNING FROM THE

SHADES. Diploma work, deposited

on his election as an Academician

Sir W. B. Richmond, R.A.

"So Orpheus, seized and torn

By the sharp fangs of an insatiate grief,

Mænad-like waved his lyre in the high air

And wildly shrieked, Where she is it is dark."-Shelley.

I39-A Fair LAND is England .. David Murray, A.

I40-Mrs. Stocks _. . . . . . Richard Jack.

I $4 \mathrm{I}$-CIRCE $\quad \ldots \quad \ldots \quad \ldots \quad \ldots \quad \ldots \quad \ldots$ Wright Barker.

I 42 - "BREAKERS AHEAD! 'WARE

Manacles!" .. . . . . C. Napier Hemy, A.

I43-Windsor Castle, I 899: portraits

W. Q. Orchardson, R.A.

I44-The Silence That IS IN THE Solemin IVOOdS $\quad . \quad \ldots \quad$ J. MacWhirtir, R.A. 
i45-The Hurrying Storil: on the

Maas, Holland....$\quad \ldots \quad F$. Spenlove Spenlove.

i 46-Sir Oswald Mosley, Bart. .. S. Melton Fisher.

I47-The Pexayce of Eleanor,

Duchess of Gloucester .. Edwin A. Abbey, R.A.

"Duch. Come you, my lord, to see my open shame? Now thou dost penance too. Look, how they gaze; see how the giddy multitude do point, and nod their heads, and throw their eyes on thee. Ah, Gloster, hide thee from their hateful looks; And in thy closet pent up, rue my shame, And ban thine enemies, both thine and mine."

r48-The Goose-Girl _. . . . . Val Prinsep, R.A.

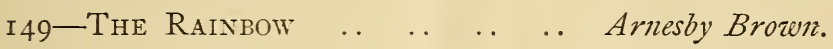
I50-Spring-Time.. $\quad \ldots \quad \ldots \quad \ldots$ Tudor St. G. Tucker. I5I-The Hill Quarry .. .. Lindsay G. Macarthur.

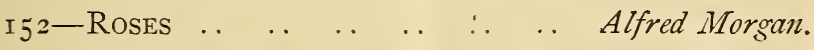
153-First Communion Day .. Henry Woods, R.A. I54-Mrs. Kleinwort .. .. . . Luke Fildes, R.A. i55-The Awakenisg of Adonis ..

J. W. Waterhouse, R.A. i56-Septeniber Morning... .. . . Samuel Reid. I57-Flight OF Huguenots FROM FRANCE : reign of Louis XIV.

G. Sheridan Knowles.

I58-". . ThE FIRST BEAM GLITTERING ON A SAIL THAT BRINGS OUR FRIENDS UP FROM THE UNDER-

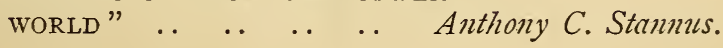


I59-A West Country Coombe ..Francis W. Reckett. i6o-Mrs. Murray Guthrie Sir E.J. Poynter, P.R.A. I6I-A Soldier's Return .. .. Marcus Stone, R.A. I62-A Quiet Nook: Kingston, Surrey

Marianne Mansell. i63-Mrs. Henry J. Hudson .. .. Henry J. Hudson. i64-Muriel and VAlÉRIE, daughters of G. A. Phillips, Esq. .. .. Percy W. Gibbs. r65-Cupid GUARding Psyche.- See the Golden Ass of Apuleius, book iv. episode $\mathrm{v}$.

I66-Flight into EGYPT

r67-The Two Crowns .. .. Frank Dicksee, R.A. i68-In Time of War A $\quad \ldots \quad \ldots$ G. D. Leslie, R.A.

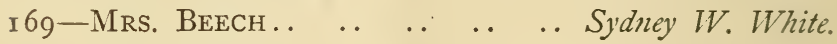
i70-A Noisy Crew ....$\quad$..

I7 I-The Glade .. .. .. .. A. Brozenlie Docharty. I72-A Signal of Distress .. .. Walter Langley. I73-Jan Panj!s .. I 74-H.R.H. The Prince OF Wales, Commodore Royal Yacht Squadron. Presentation portrait

$W$. IV. Ouless, R.A. I75-Hill, Vale, and Stream.. B. $W$. Leader, R.A. i76-Castles in the Air .. .. .. Tom Mostyn. I77-A Winter's TALE : funeral blessings, Holland .. $\quad . \quad \quad F$. Spenlove Spenlor'e. i78-The Coast of Cornwall .. $H$. Musgrave. 
I79-"'Twas in the Summer-time so

Sweet" ..

I80-General H.R.H. The Duke of

Connaught, K.G. .. Hubert von Herkomer, R.A. I8I-After the Heat of the Day :

near Cairo.. $\quad . . \quad$.. $\quad . \quad$ Fredk. Goodall, R.A. i 82-The Earl of Stradbroke ..Arthur S. Cope, A. i83-Portrait of a Gentleman .. J. W. Brooke. I84-A Flying Visit .. .. $\quad . . \quad$.. Kate Perugini. i 85-Soimtude $\quad . \quad \ldots \quad \ldots \quad \ldots \quad \ldots \quad \ldots$ George Clausen, A. i86-The Evening Hymn .. George H. Boughton, R.A. i87-Hartlesham Marshes .. Edward T. Lingwood. i 88- Whitby Church and Cross .. George L. Leigh. i89-Lady Currie $\quad . \quad \ldots \quad \ldots \quad$. $W$. Ouless, R.A. I90-The LoRd Russell of KiLLOWEN, Lord Chief Justice of

England .. $\quad . . \quad$.. $\quad . . \quad J o h n$ S. Sargent, R.A. i9i-The Open Sea .. I92-The Edge of THE Moor.. Edward T. Lingwood. i 93-Forest Pastures .. .. Ernest A. Waterlow, A I94-Sir John Evans, F.R.S. Painted for the Royal Society.. . . . . Arthur S. Cope, A.

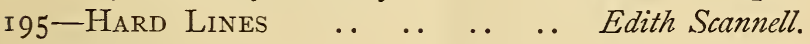

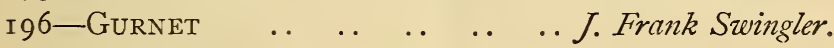
I97-The Lord Kitchener of KhaR-

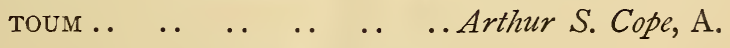
i98-The Great Nile Dam, Assouan Andrew C. Gone, R.A. 
I99-DAWr 200-ON THE Rhyw, Montgomeryshire Trez'or Haddon. 20I-“APrès?" Diploma work, deposited on his election as an Academician

$$
\text { E. J. Gregory, R.A. }
$$

202-Old Sopley.. ..

203-"Where THOUGHTS ARE SINGING SWALLOWS, AND THE BROOKS OF MORNING RUN" .. 204-"Fate LEAdS THE WILLING AND THE UNWILling DRAGS".. .. Talbot Hughes. 205-Ere the Winter Storms Begin Frank P. Freyburg. 206-" OCEAX'S SURGE, WHITE AS THE SEA-BIRD'S WING" $\quad$. $\quad$.. Peter Graham, R.A. 207-The Return of Godiva .. .. G. F. I Watts, R.A. 208-Tempting . . . $\quad$.. $\quad . . \quad$.. Delapoer Downing. 209-In a Perthshire Deer-Forest Charles Stuart. $210-$

"Then the old hag drew out three caskets, one red, one blue, and one green, and of these the lassie was to choose one for her service. Now she didn't know at all which to choose, but the little birds sang :-

'Don't take the red, don't take the green, But take the blue, where may be seen, Three little crosses all in a row ;

We saw the marks and so we know." "-Norse Tales.

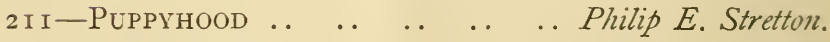
2I 2-The Goatherd .. .. .. James C. Hook, R.A. 2I3-Lady Elcho, Mrs. Adeane, ANd Mrs. Tennant _. .. John S. Sargent, R.A. 
2 I4-The Marsh Pool .. .. .. Tom Mostyn.

2I5-ThE VALLEY OF THE Frome,

Dorset .. .. .. .. .. Arthur Meade.

2 I6-The Turn of the Tide .. .. Arthur C. Cooke. 2I7-Sunny Woods .. .. .. .. Frank H. Walker. 2i 8 - A New Coat for an Old Friend J. C. Hook, R.A. 2 I9-St. George .. $\quad$.. . . . . Briton Riviere, R.A.

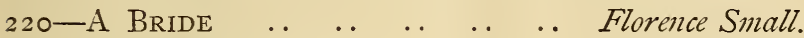

$22 \mathrm{I}$-The Wind-Flower $\ldots \quad \ldots \quad \ldots$ IV. H. Margetson. 222 -An Autumn Afternoon .. .. J. Aumonier. 223-Crystals and Ores .. .. Catherine M. Wood. 224 -Water Babies .. .. Sir E.J. Poynter, P.R.A. 225 -Miss Evelyn Ouless .. Henry T. Wells, R.A. 226-Goldfish . . . . Sir L. Alma-Tadema, R.A. 227 -Twilight Grey .. .. .. H. $W$. B. Davis, R.A. ".... And twilight grey

Had in her sober liv'ry all things clad."

2 28-The Towing-Path . . . . Lexden L. Pocock. 229-ST. FRANCIS AND THE BIRDS ON

VERna $\quad \ldots \quad \ldots \quad \ldots \quad \ldots \quad$ IVilliam B. Adenej.

230-A Portrait of a Ladi .. .. Sydney Lee.

23 I-Miss F. Allen .. .. .. Francis A. Haviland.

232-Near Greenlands, Henley-on-

Thames .. $\quad . \quad \ldots \quad \ldots \quad$. . Samuel Bateman.

233-In Maiden Meditation .. .. James Sant, R.A. 


\section{GALLERY No. IV.}

\section{OIL PAINTINGS-(Nos. 234-318).}

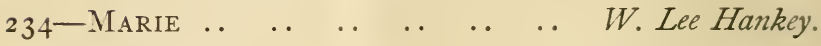
235-Background of Gold .. .. William Bramley.

"If I could have that little head of hers on a background of pale gold."

236-W. Wilson Fitzgerald, Esq. . Frank Bramley, A. 237 -UNA AND THE Wood-Gods .. Tohn da Costa.

"The wild wood-gods, arrivéd in the place, There find the virgin, doleful, desolate,

With ruffled raiments, and fair blubber'd face,

As her outrageous foe had left her late."

Spenser's 'Faery Queen, canto 6, verse 9.

238-Autumn Labour.. .. .. .. George Gascoyne. 239-IN THE BLUE ARIZONA-night :

telling fortunes .. $\quad$. . . . . Fernand Lungren.

240-A STUDy: head of an old woman Edith Lumley.

24 I-Bontigues Chasm, Sark .. . Ethel Martin.

242 -Chinese Lanterns .. .. Catherine M. Wood.

243 -Washing-Day $\quad . \quad \ldots \quad \ldots \quad \ldots$ Mark Senior.

244-"They ALSO SERVE WHO ONLY

STAND AND waIT".. .. .. Spottiswood Duthie. 


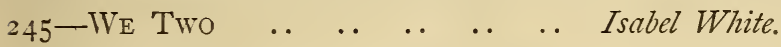

246-Franciscans at Prayer : Reden-

tore, Venice $\quad . \quad \ldots \quad \ldots \quad \ldots H$. Randolph Rose.

247-Shrimpers : Normandy .. .. Terrick Williams. 248-Mrs. Chadwyck Healey and

her Daughter .. .. .. Walter Osborne.

249-When SUn is Set .. .. $\quad$ B. W. Leader, R.A. 250-The Pillion $\quad . \quad$.. $\quad . . \quad$.. $\quad J$. Walter West. 25I-ARIShMell GAP, Dorsetshire : moonlight .. $\quad$.. $\quad$.. $\quad$.. $\quad$.. Arthur P. Burton. 252-Mrs. Adolph Tuck .. .. .. Herbert Horwitz. 253-The Dragon-Fly .. .. .. Thomas Cowper. 254-Into the Silent Sea A $\quad . . \quad J$. T. Neltleship.

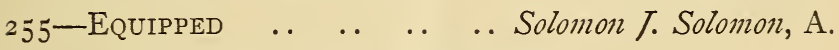
256-"WheN THE Mist WITH EVENING GLOWS"

257-Exchange is No Robbery 258-An Old Castilian .. .. J. Sorolla y Bastida. 259-Lengthening Shadows .. .. James L. Henry.

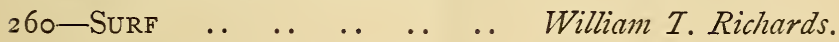
26I-The Eve of a Storm .. J. Richard Bagshawe. 262-Lady Stephenson. Presentation Portrait .. $\quad$.. $\quad$.. $\quad . . \quad$.. Arthur S. Cope, A. 263-The Mysteries of the Deep.. E. F. Brewtnall. 
264-BIRdie LeWIN-granny's darling Marie Lucas. 265-Haabetje, Jaapje, and Ant .. M. Agnes Cohen. 266-A Golden Valley .. .. .. George Wetherbee. 267-After the Day's Toll .. Edward G. Hobley. 268-A Morning Moon .. .. .. Alfred East, A. 269-Once Bit, Twice Shy .. James C. Hook, R.A. 270-The Road from Gizeh to Cairo

G. Hillyard Suinstud. 27 I-Her Last Signal .. .. J. Richard Bagshauie. 272-The Red Gown... .. .. Kenneth M. Morrison. $\begin{array}{lllll}\text { 273-Stepping-Stones } & \ldots & \ldots & \\ \text { 274-Nrs. Elaier Speed } & \ldots & \ldots & \text {.. } \\ \text { 275-Blake's Great Naval } & \text { Engage- }\end{array}$ ment with Van Tromp, i653 W. L. Wyllie, A. 276-Good-Bye! The 3rd Battalion Grenadier Guards leaving Waterloo Station, October 2 I, I $899 \ldots$

277 -ORPHANS 278-Mrs. Montgolierie .. .. Henry T. Wells, R.A. 279-A Surrey Trout-Streali .. James C. Hook, R.A. 280-A Grey Day .. .. .. .. J. Clayton Adams. 28I-The Story of the Wreck .. George H. Jupp. 282-H. J. Leech, EsQ. .. $\quad . . \quad$.. Percy Bigland. 283-View in Essex .. $\quad . . \quad \ldots \quad$.. Mark Fisher. 
284-Dorothy AND Irene, daughters of C. L. Falkiner, Esq. . . . . Walter Osborne. 285-The Awakening _. .. . . W. Dendy Sadler. 286-Miss Flora Siith .. .. .. J. Watson Nicol. 287-A Sitter of 90.. .. .. .. Horace Van Ruith. 288-A Northerly Breeze .. .. Stuart Hobkirk. 289-A Normandy Hillside .. Charles H. Eastlake. 290-The Gates of Dawn .. .. Herbert J. Draper. 29I-The Dark Bari .. .. .. George Clausen, A.

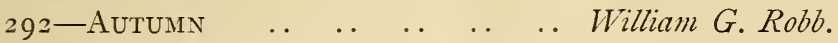
293-Phyllis, daughter of Dr. and Mrs.

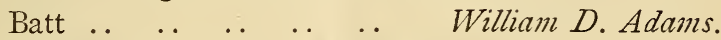
294-The Passing Storm: Montigny-

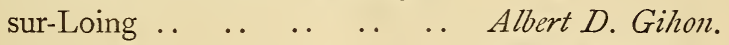
295-The Drinking Pond .. .. Terrick Williams. 296-Loben, son of E. A. Maund, Esq. Ralph Peacock. 297-La Vierge aux Lys .. .. .. W. A. Bouguereau. 298-Morocco Coast .. $\quad . . \quad$.. $\quad$.. $\quad$ E. Aubrey Hunt. 299-Mrs. F. GuUld ....$\quad$.. $\quad . . \quad$ Walter Urwick. 300-Under the Sea-WaLl .. .. Robert Noble. 30I-Bygone Days .. 302-Ordered South .. $\quad . . \quad$.. . . John H. F. Bacon. 303-In the End of Autumi .. .. James $V$. Jelley. 304-Ianthe .. $\quad$. $\quad$.. $\quad$. $\quad$.. $\quad$.. Arthur P. Burton.

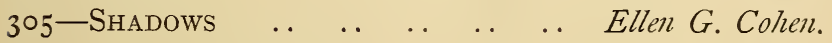
306-In the Marshes .. .. .. Gussie Lindner. 
307-Midsummer Morn .. $\quad . . \quad$.. Percy Buckman. 308-A Nameless Dell .. .. J. MacWhirter, R.A. 309-"Musicienne du silence" .. Arthur Hacker, A. 3io-Enid Mary Whitely .. .. John W. Whitely. 3i I-The Turn of the Plough Sidney M. Hallowes. 3i 2-Moonrise: Conway Valley .. J. Hamilton Hay. 313-Storir Clouds .. 3I4-Goldex Leaves _. .. J. MacWhirter, R.A. 3i5-Under the Tree .. .. .. George Clausen, A. 3i6-Winter .. 3i7-Elinor, daughter of Lady Blomfield .. 3I8-Clouds .. 


\section{GALLERY No. V.}

\section{OIL PAINTINGS-(Nos. 319-393).}

3i9-Miss Violet Corry .. .. .. H. Harris Brown. 320-"RINGS AND ThINGS AND FINE

ARRAY" $\quad$.

32 I-A Study of Fruit .. .. .. Amy C. Warne.

322-Spring ..

323-The In-coning Tide.. .. .. Fred Appleyard. 324-Children on the Sea Shore William Shackleton. 325-"AND STEEPED IN SUMMER SLEEP

THE WORLd MUST LIE" .. .. Wm. H. Bond.

326-Home from Pasture.. .. .. J. Coutts Michie.

327-The Squire's Song .. .. . . I W. Dendy Sadler.

328-The FALL of the LeAF .. Edward W. Waite.

329-An Idyll of Summer .. .. Arthur Wardle.

330-Good News from the IVAR .. W. H. Y. Titcomb.

$33 \mathrm{I}$-Happiness $\ldots$.. $\quad . . \quad$.. Richard W. Maddox.

332-The River Meadow .. .. Bertram Priestman.

333-Sir John Wolfe Barry, K.C.B.

Presentation Portrait Hubert von Herkomer, R.A.

334-The Drinking-Place .. Stanhope A. Forbes, A. 
335 - $\quad \ldots \quad \ldots \quad \ldots \quad \ldots \quad \ldots \quad \ldots \quad \ldots$ Alfred Ward.

"And tear and sorrow and scorn,

Kept watch by his head forlorn,

'Till the night was overworn,

And the world was merry with morn."

A. C. Swinburne.

$336-A$ SEA IVAIF

Edward Patry.

337 -Winter Ploughing .. . . . . N. H.J. Baird.

338-Henry Allhusen, Esq., M.P... Richard Jack.

339-"AND ALL THE AIR A SOLEMN

SILENCE HOLDS" .. .. Joseph Farquharson.

340-The Viking's Home-Coming .. Herbert Gandy.

"Proud of his royal bride, the richer spoil."

34I-A Winter Morning .. .. J. H. Vignoles Fisher. 342-The Mower .. .. .. Thomas F. M. Sheard. 343-A Mevagissey Lugger Leaving HARBOUR .. $\quad . . \quad \ldots \quad \ldots \quad . . \quad$ Fritz Althaus. 344-The King's Garden.. .. .. Arthur A. Dixon. 345-IVAR News in THE Streets:

England, i900 .. . . . . . Ellen Clacy.

346 -Anxious News .. .. . . . . $\quad$ E. E. Lucas.

347 -Pear-Blossom .. . . . . . Clara L. Christian.

348-Knockhundred Row, Midhurst Ida Morley.

349-The Bulwarks of England .. Arthur Burchett.

350- "BY THE DARK WATERS OF FOR-

Getfulness" .. .. George H. Boughton, R.A.

$35 \mathrm{I}$-The Water-Plash .. .. H. H. La Thangule, A.

352 -A Study in Glass .. .. ...Augusta M. Bowen.

353-A Surrey Shepherd.. . . . May Fumiss. 


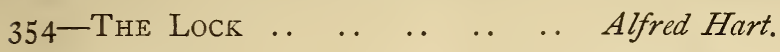

355-Autumn _. .. $\quad . . \quad \ldots \quad$ W. Westley Manning.

356-When Winter has Passed .. T. F. Goodall.

357-Autumn on the Derinent .. Frank T. Carter. 358-The Quarrel .. .. .. .. Alfred J. Dobson. 359-Hermes at the Pool .. .. Henry S. Tuke, A. 360-The Silent Life .. .. .. Dora Noyes. 36r-Main Street, Montreuil-sur-Mer, from the bridge 362-Money-Changer: Bombay 363-Through the Stubbles 364-Summer-Time 365-The Old Bridge in Verona .. 366-Penelope ANd the Suitors- Odyssey

367 - "The SEething tUMULT OF OUR WAKE" 368-The Foreshore, Newlyn .. .. Reginald T. Dick. 369-Mrs. Handfield Jones .. Hugh de T. Glazebrook. 370- "ThROUGH THE MIST OF PAST years." - Keats . . . . .. Frank Bramley, A. 37 I-Madale Michaelis $\ldots$.. $\quad . . \quad J$ J.J. Shannon, A. 372-September on the Arun... .. José Weiss. 373- "AND WONDERED AT THE FAIR FACE MIRROR'D THERE" .. .. Hannah Myers. 374-The Weir Pool.. $\quad . \quad$.. . . Arthur Meade. 375-The Lady of Shalott .. George E. Robertson. "Out upon the wharf they came, Knight and burgher, lord and dame."-Tennyson. 
376-"AT THE CLOSE OF THE DAY,

When the hamlet is still" $B . W$. Leader, R.A. 377-C. A. CRipps, EsQ., Q.C., M.P. W. W. Ouless, R.A. 378-The Lone Tree.. .. .. .. Frank Walton.

379-Lowlanders : on Loch Tay, Perthshire .. 380-Cupid's Well $\ldots$.. $38 \mathrm{I}$-The Derelict $\ldots$.. 382-Britannia's Nursery .. .. Arthur J. Foster. 383-A Study ....$\quad$.. 394-Miss Katherine V. Charrington

Henry T. Wells, R.A. 385-The Latest Scandal .. .. Adam E. Proctor. 386-The Evenings Hour : tunny boats,

Brittany .. $\quad . . \quad \ldots \quad . . \quad W$. Westley Manning.

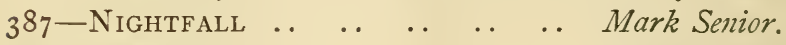
388-Summer $\quad$. 389-Miss Margaret Bradish.. .. Frank Brooks. 390-Sleeping Nymph _. .. .. Arthur P. Burton. 39I-An Old Favourite .. ... Alfred J. Munnings. 392-The Dawn of Womanhood .. T. C. Gotch.

"The child, enthroned, sees in a vision approaching womanhood : the phantom figure wears a mask, since all who are no longer children must conceal themselves. The familiar spirit of childhood, on the steps of the throne, is aware of a strange presence, and prepares to fly away."

Dream Pictures.

393-John A. Dewar, Esq., ex Lord Provost of Perth. Presentation Portrait .. $\quad$.. $\quad$.. $\quad$.. $\quad$.. Thomas Graham. 


\section{GALLERY No. VI.}

OII PAINTINGS-(Nos. 394-522).

394-In a London Garden .. Hugh de T. Glazebrook. 395-Her Ladyship .. $\quad . . \quad$.. $\quad$. $\quad$ Rudolf Lehmann. 396-Rudyard Kipling, Esq. .. ... Sir P. Burne-Jones. 397-Homewards.. $\quad$. $\quad$. . $\quad$. $\quad$.. Mark Senior. 398-Summer Ploughing .. .. . . Robert H. Buxton. 399-A Peep at Rabelais.. .. .. Herbert Ward. 400-Market-Day: Pont Aven .. .. Terrick Williams. 40 I-Sunset on the Canal .. .. Charles W. Wyllie.

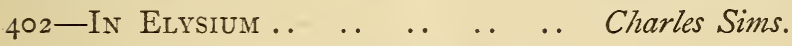
403-"Better is A DiNNer OF HERBS WHERE LOVE IS, THAN A STALLED OX AND HATRED THEREwith."-Prov. xv. I7 .. George W. Joy. 404-EXCOMMUNiCATED

...S. Pepys Cockerell. 405-An Old Garden .. .. .. Dion C. Calthrop. 406-June Hay .. 407-A Rain Cloud .. .. .. Frederic A. Winkfield. 408-Don Marescotti Ruspoli .. Mary L. Waller. 409-On the Shore at Rye .. .. Edith P. Quicke. 4ro-The Letter .. .. .. .. Clara L. Christian. 
4II-BISON

4I 2-Saliion-Spearing 4I3-Hill and Vale.. 4I4-Crossing the Deser'i 4I5-The Old Lacemaker 4I6-The Sheepfold .. 4I7-WILD Roses.. 4I8-Messack Point, from near St. Mawes
4I9-Sanuel Whitbread, EsQ. Presentation Portrait .. .. . . Hon. John Collier. 420 - Fleeting Sunshine in the Vale $42 \mathrm{I}$-The Landing-Place .. 422-FRESH FROM THE KITCHEN

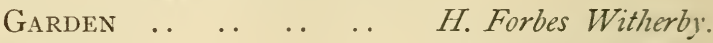
423-Miss Bishop .. $\quad . . \quad \ldots \quad$.. William E. Miller. 424-"Where Was Maud? IN OUR WOOD; AND I, WHO ELSE, WAS WITH HER" 425-Frutt .. 426-SyBIL, daughter of Colonel G. F.

Scott .

427-Horses Bathing in the Sea Lucy E. Kemp-Welch. 428-The Way to the Village .. George Ransom. 429-A Dash FOR Freedou .. .. Claude Cardon. 430-An Old Sand-Pit .. .. .. $\quad$ A. E. Bailey: 43I-Making Paper Roses for St. George's Day.. .. . . Mary E. Postlethriaiti. John F. Slater. Emily Duncan.

Frederick A. Verner. Alexander G. Small. Mark Fisher. Frank Dean. Agnes D. Terry. A. Miles Albert.

Charles Collins. 
432-Bellagio, from Cadenabbia .. Graham Petrie. 433-A Poacher .. $\quad . . \quad$.. . . . . Philip E. Stretton. 434-Roscoe Brunner, Esq. .. . . Arthur Hacker, A. 435-A Mountain Torrent .. .. Albert Kinsley. 436-Monaconi Rocks, Capri .. .. Gwilt Jolley. 437-A Night Alarm .. .. .. J. Sidney Steel. 438-A Garden of Lyonesse .. .. Gilbert Foster. 439-Spring's Delights .. .. . . R. Vicat Cole. 440-An Unexpected Return.. . J J. V. R. Parsons. 44I-The High Poplars .. .. ..Philip T. Gilchrist. 442-One at a Time.. $\quad . . \quad \ldots \quad \ldots$ Alfred $W$. Strutt. 443-Moonrise on the Tay .. .. Tom Robertson. 444-The Hearth Witch .. .. . . Marie Lucas. 445-Hay-Time in Wharfedale .. M. Raphael Jones. 446-Priscilla .. 447-The Dedication of St. Elfleda

Katherine M. Roberts.

448-NonPlussed. . 449-A Redesdale Landscape.. 450-RHODODENDRONS.. 45 I-DESPATChes .. 452-A Daughter of Erin 453-A Difficult Task 454-The White Cloud 455-The Gap in the Hedge .. 456-REJECTED
. Margaret Collyer. Hon. Walter J. James.

. Jessica Hayllar.

.. Frank J. Torromé.

. C. Kirchmayr.

.. Charles Spencelayh.

. J. Johnston Inglis.

.. George Clausen, A.

.. Lex de Renault. 
457-October 458-L. Bischoffshein, Esq. .. .. Emile Wauters. 459-October Moonrise .. .. .. R. Crafton Green. 460-White Butterflies .. .. .. $\quad$ E. Richardson. 46I-The Uninvited Guest .. .. Charles Collins. 462-A Bye-way in Katwy .. .. M. Agnes Cohen. 463-The Source of the Sacred

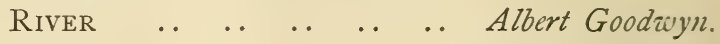
464-"It is OUR OPENING DAY" G. F. Jacomb-Hood. 465-Cloud-Shadows on a Hill: a sketch at Tigh-na-bruiach .. Alice Fanner. 466- "THE HEAVENS KNOW BEST WHAT IS THE BEST FOR ME."-

Spenser .. $\quad \ldots \quad$.. $\quad \ldots \quad$.. Frank O. Salisbury. 467-The Sisters _. 468-Brought to Book .. .. Charles E. Richardson. 469-La Bonne Mère s'endort .. Ella M. Bedford. 470-Sunshine and Shadow .. .. Henry H. Power. 47 I-After Sundown.. .. .. .. Charles H. Mackie. 472 -Louis N. Parker, EsQ. .. ...Sir P. Bume-Jones. 473-Madane X... .. . . . . . . Lex de Renault. 474-La Jeunesse .. 475-The Suburbs of Zeriati .. Bryan Hook. 476-Penny a Bunch.. .. .. .. George E. Hicks, 477-The Flower-Markets in Paris: sunlight and shadow .. $\quad$.. Stuart Hobkirk. 478-Keswick Lake, Cumberland .. Jane Ross. 
479-AT LAST!

480-Goblin Market.. $48 \mathrm{I}$-A Remnant 482-A Devonshire Cottage 483-Horatio Brown, EsQ. $484-\mathrm{M}$
.. Edward P. Porter. L. Gwenllian James. Newton Braby. Jonathan Pratt. .. .. Henry S. Tuke, A. AND HER

$$
48
$$
$87-$ 488-An Illustrated War-Paper 489-Morning 490-An Old World Village.. 49I-EVENING 492-Rev. J. P. Mahaffy, D.D. $\begin{array}{llll}\text { 493-In a Dorset Village } & \ldots & \text {.. } \\ \text { 494-Mona : a Portrait } & . . & . . & \ldots \\ \text { 495-Rapanzel : from a Poem } & \text { by }\end{array}$ $\begin{array}{llll}\text { William Morris } & . & \ldots & \ldots \\ \text { t. Hon. Sir Massey Lopes, }\end{array}$

Bart. Presentation Portrait. .. Arthur S. Cope, A. 496-RT. Hon. SiR
BART. Pres
497-AN INTERIOR 
502-Mill-Stream, below Assisi

.. Edith Corbet.

503-The Sale of Old Dobbin 504 -Solitude

505-PEGGY AND KitTy, daughters of E. A. Barry, Esq. .. $\quad . . \quad$.. Marie Lucas. 506-The Denial 507-GEESE .. 508 -FORSAKEN

509-The River From the Pier,

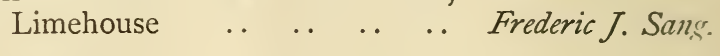
5IO- A Sunny Morning before 5I I - Michaelmas $\ldots$.. 5I3-The River, near Southend .. Frederic J. Sang. 5i4-A Question of Compensation John C. Dollman.

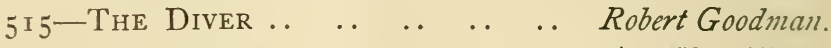

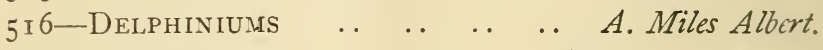
517-A Dance $\quad . \quad \ldots \quad \ldots \quad \ldots \quad$ Alfred D. Lancaster. 5i 8-The Reservist's Wife .. .. Ralph Hedley. 5i9-The Queen of Hearts .. .. Blanche Jenkins. 520-WeEd fOR the Plots .. .. John White. 52 I-Porpoise Catching .. .. .. E. Matthew Hale. 522-An Autumn Morning .. .. Arnold Priestman. 


\section{GALLERY No. VII.}

OIL PAINTINGS-(Nos. 523-610).

523-White Peonies .. .. .. Janetta R. A. Pitman. 524-A Peasant Girl From the Mountains : Feltre.. .. .. Hilda Montalba. 525-Wild Parsley .. .. $\quad . . \quad$.. Bertha King. 526-Philomel .. $\quad . . \quad \ldots \quad \ldots \quad$ George A. Storey, A. 527-The Fold YARd.. .. .. . . Yeend King. 528-Life's Immensity .. .. .. Henry J. Stock.

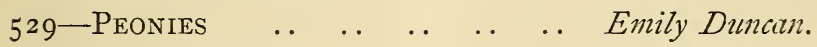
530-Miss Vaughan .. 53I-A Landlocked Bay, South Devon

Frederic $A$. Winkfield. 532-Meditations $\quad . \quad \ldots \quad . . \quad$.. John Lee. 533-Joan of ARC . 534-Awake! Awake! .. .. .. Lionel A. Talbot. 535-A Grey Day . $\quad . . \quad \ldots \quad \ldots \quad R$. Onslow Ford. 536-The Cape of St. Anthony J. Sorolla y Bastida. 537-Sir G. C. H. Armstrong, Bart.

Hubert von Herkomer, R.A. 538-Winter's Sleep .. $\quad . . \quad \ldots \quad$.. Harry W. Adams. 
539-B. L. Cohen, Esq., M.P... Solomon J. Solomon, A. 540-The Crisis .. 54I-Richnond, Yorkshire.. .. .. Vincent P. Yglesias. 542-Leda and the Swan.. .. .. W. G. von Glehn. 543-Cape St. Vincent .. .. .. W. Ayerst Ingram. 544-Lake Bourget, from Mt. Revard, Savoy ..

545 -Septimus Vaughan Morgan,

EsQ. .. 546-The Cruel Sea .. .. .. .. Harrington Mann. 547-A Himalayan Glacier .. .. Edward Molyneux.

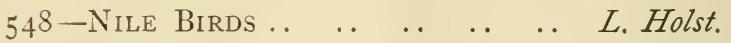
549-Arthur Keen, Esq. .. Hubert von Herkomer, R.A. 550-The Avon, by Beedon Hill .. Yeend King.

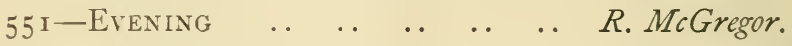
552-After a Famous Victory.. Tudor St. G. Tucker. 553 -Farm on the South COAST .. Mary Lanchester. 554-The Rose and the Ring .. Norman Garstin. 555-A Dim Trail: cowboy trailing stock ..

556 - MARL POND.

557-A Profile .. .. . . . .. .. $\quad$ I. L. Gloag.

558-The Colne.. .. . . . . . . Dazid Murray, A.

559-A. N. Hornit, Esq. Presented to him by some friends and members of the Lancashire County Cricket Chub.. ....$\quad$.. $\quad . . \quad W$

Fernand Langren. Anderson Hague. 
56I-Poppies 2.. $\quad . . \quad \ldots \quad$.. E. Margaret Woolhouse. 562 -Wandered from the Lair .. C. E. Swan. 563-A Summer Morning .. .. ..J. Barnard Davis. 564-Georgette, daughter of George Mosenthal, Esq. . . $\quad$.. $\quad$.. $\quad$ Ralph Peacock.

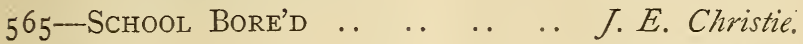

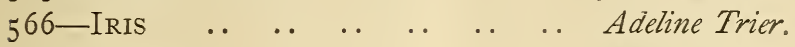

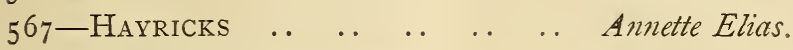
568-Sir Squire Bancroft .. .. Hugh G. Riviere. 569-The Ploughboy.. .. .. H. H. La Thangue, A. 570-Mrs. C. HAigh-IVood .. .. C. Haigh-Wood. 57 I-A Hot Summer's Day .. .. Harry Watson. 572-Mrs. Phillip Hughes A. .. George S. Watson. 573-In the Orchard .. .. .. Dudley Heath. 574-Meadowsweet .. .. .. $\quad$.. A. Dampier May. 575-Dawn in the Pilgrim's Road Albert Goodwin. "And an highway shall be there, and a way, and it shall be called The way of holiness; the unclean shall not pass over it ; but it shall be for those : the wayfaring men, though fools, shall not err therein."-Isaiah, xxxv. 8.

\section{6-The MilL}

577-PORTRAit O

578 -ASSISI

579-MR. BELL

580 -WORSTED

$58 \mathrm{I}$-Miss Logan

582-WHere BroOK

MEET
- Alfred May.

L. Gwenllian James.

L. Gwenllian James.

.. Herbert A. Olivier.

. C. M. Padday.

Fredk. Goodall, R.A.

AND Streamlet

. $\quad$.. $\quad . . \quad$. J John H. Dearle. 
583-Mrs. E. Snow .. 584-A Critical Moment at Quatre

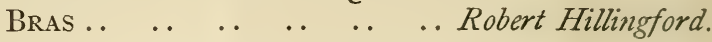
585 -The Hon. Mr. Justice Kennedy Sir W. B. Richmond, R.A. 586-The Market Cart : Egypt Fredk. Goodall, R.A. 587 -Violet, Geraldine, Constance, the daughters of Sir Oswald Mosley, Bart. .. $\quad . . \quad$.. .. S. Melton Fisher. 588-in a Sutherlandshire Deer-

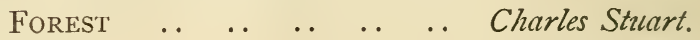

589-ReCalled to Life. - 'Tale of

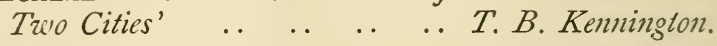
590-Vincit Æthiops _. .. .. Frank J. Torromé. 59I-William W. Portal, Esq. ..Arthur S. Cope, A. 592-Ecce Agnus Dei .. .. A. Chevallier Tayler. 593-Mrs. G. F. Scott .. .. ... Sigismund Goelze. 594-The Princess of OnCE-UPON-ATrme..

So the wicked Queen and her lady-in-waiting bound the Princess to a tree, and left her in the forest.

595-A Cottage by the Sea .. .. James S. Hill. 596-Freshwater Cliffs, Isle of Wight : herring gulls mobbing a peregrine George E. Lodge. 597-John Woodrow Cross, EsQ. Presentation Portrait .. Solomon J. Solomon, A. 598-A Nor'wester .. .. .. J. Richard Bagshazue. 
599-A Cotswold Manor House

Alfred Waterhouse, R.A. 6oo-Portrait of a Gentleman .. W. Onslow Ford. 6oi-Dumplings 602-A Capri Girl .. .. .. William R. Lavender.

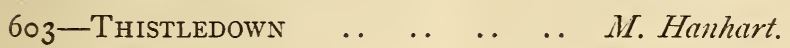

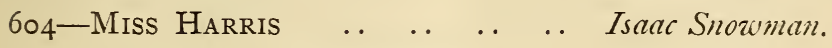
605-Monsieur A. H. Benoist .. Will Brock. 606-God Speed .. $\quad . . \quad$.. $\quad$.. $\quad$.. E. Blair Leighton. 607-Mrs. Charles Murray .. .. Charles A. Buchel. 608-VIEW FROM THE OLd BRIDGE IN

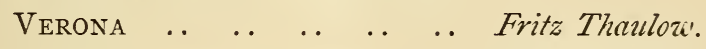
609-Mrs. Charles A. Buchel .. Charles A. Buchel. 6io-Cape Goosebellies .. .. E. Archibald Broitm. 


\section{GALLERY No. VIII.}

\section{OIL PAINTINGS-(Nos. 611-685).}

6 I I-Sunshine And Shadow: Winchelsea $\quad \ldots \quad \ldots \quad \ldots \quad \ldots \quad \ldots \quad$ Charles Smith. 6r 2-Golng to Work.. .. .. . .F. Mabel Hollams. 6I 3-The Poultry YARd .. .. . . Eyre Crowe, A. "While the cock with lively din,

To the stack, or the barn-door, Stoutly struts his dames before." - ''Allegro.

6i 4-The Good Samaritan .. .. Frank C. Cowper. 6i5-A MoORland Incident .. .. Wright Barker. 6i6-Idle Dreams .. .. .. Anna A. Mac Rory. 6i 7-Miss MCGAw .. ... ..Hugh de T. Glazebrook. 6i 8-Village Life .. .. .. . . James Charles. 6r9-A Lady of Quality: Mistress Clorinda shines on her birthday night .. $\quad \ldots \quad \ldots \quad \ldots \quad \ldots$ Frank $W$. W. Topham. 620 -SPRING .. . . . . . . . . T. Sidney Cooper, R.A. "In the spring-time of the year." 
62 I-The Latest Arrival .. R. Gemmell Hutchison. 622-Ploughing on a Breezy Day...ArthurNetherwood. 623-The Charge OF THE 2 IST

Lancers at Omdurman .. Allen Stewart.

624-A Glen in North Wales .. John Finnie. 625-Sir David Richmond, ex Lord Provost of Glasgow. Presentation Portrait .. .. .. John S. Sargent, R.A. 626-Summer _. .. .. .. T. Sidney Cooper, R.A. "A various group the herds and flocks Compose; rural confusion! On the bank Some ruminating lie; while others stand Half in the flood, and often bending Sip the circling surface."

627-H.R.H. THE PRINCE OF WaLES. Exhibited by command of H.M.

the Queen .....$\quad$.. $\quad . . \quad R$. Caton Woodville. 628-The Lady Inchiquin .. ... Herbert J. Draper. 629-Huntixg Scene .. .. .. . . Charles Lutyens. 630-The LoRd Russell of Killowen, Lord Chief Justice of England

63i-Autumn $\quad . \quad \ldots \quad \ldots \quad \ldots$ T. Sidney Cooper, R.A. John S. Sargent, R.A "The sear, the yellow leaf-time of the year."

632-Winter: through the Fells, Cumberland; the drove in a snowdrift .. $\quad . . \quad \ldots \quad \ldots \quad \ldots$ T. Sidney Cooper, R.A. 633-Wild Sussex _. $\quad . \quad \ldots \quad \ldots$ José Weiss. 634-Frost FAIR, $\mathrm{I}_{68}$ H $\quad$.. $\quad$ H. Gillard Glindoni. 
635-John Robertson, Esq. .. . . J. Young Hunter. 636-The Greek Runner Ladas Falling Dead as he goes to Receive his Crown at

Olympia .. 637-Called to the Front .. H. Gillard Glindoni. 638-Storni Weather: Enkhuyzen

Harbour, Zuyder Zee .. .. Edwin Hayes. 639-Edwin SaChs, EsQ. .. .. .. Ada Holland. 640-Sweet Peas.. .. $\quad . . \quad \ldots \quad$.. Lydia B. Mather's. $64 \mathrm{I}$-The Young Ensign .. .. Kenneth M. Morrison. 642-"O SWEet Pale Margaret"Temny'son .. $\quad$.. $\quad$.. . . J John F. H. Dutton. 643-"Shadows of The EVENing FLEeT aCross THE SKY" 644-Night's Awakening .. . . F. Spenlove Spenlote. 645-Sir Lowthian Bell, Bart. .. Frank Bramley, A. 646-LONDON FROM THE TOWER

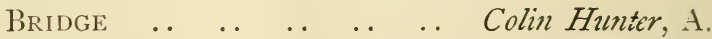
647-Hudson E. Kearley, Esq., M.P. H. Harris Brozin. 648-A Wind-swept Wessex Valley

E. R. Ireland Blackburne. 649-Lights that Guide and Guard Louis Grier. 650-J. C. Deverell, EsQ. .. Fredk. Goodall, R.A.

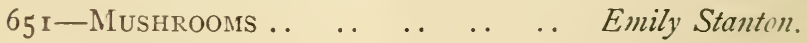
652-A Hundred Years Ago .. .. George Wright. 653-Octaviax before Cleopatra .. 
654-Fräulein Valerie Degenhardt Adolf Thiede. 655-Aт his Wits' ENd .. .. $\quad$. Alfred $W$. Strutt. 656-Sweet Memories .. .. ...Spottiswood Duthie.

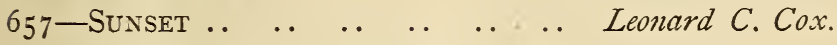
658-Early Autumn: near Bettws-yCoed .. $\quad . . \quad$.. $\quad$. $\quad$.. $\quad$ William E. Benger.

659-Twilight : "Tall woods, with dim romances blent."-Keats.. Lionel Birch. 660-"OF OLD UNHAPPY FAR OFF Days, And battles long ago" Jane A. Ram. 66I-Coming from the Fair .. .. Phil R. Morris, A. 662-A Summer Cloud .. Sir W. B. Richmond, R.A. 663-Golden Hours .. .. .. .. John White. 664-Colonel Inigo Jones .. ...T. Blake Wirgman. 665-A Highland Loch .. .. .. Douglas Adams. 666-Evening on a Welsh Estate.. Trevor Haddon. 667-Children of J. Binney, Esq... W. R. Symonds. 668-Miss Elena M. Grace Hubert von Herkomer, R.A. 669-Denounced .. $\quad . . \quad$.. $\quad$.. H. Gillard Glindoni. 670-In an Asolan Garden .. .. Herbert A. Olivier. 67 I-The Mermaid $\quad . \quad \ldots \quad$. $\quad . \quad$ Rowland Holyoake. 672-Pastorale Provençale .. Emest A. Waterlow, A. 673-Mrs. Stirling Stuart .. .. Arthur Hacker, A. 
674-The Hero of the Hour.. .. Fred Morgan. 675-A Fisherman's Cottage .. .. Vincent P. Yglesias.

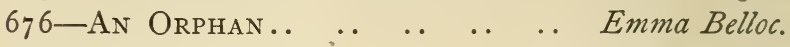
677-Fruit and Wine .. .. .. William Hughes. 678-The Voyage of St. Patrick .. T. Butler Stoney. 679-The Favourite .. $\quad . . \quad$.. ... P. Harland Fisher. 680-Spring Sunshine .. $\quad . . \quad .$. Robert W. Allan. 68I-A Wild Flower .. .. G. Hillyard Swinstead. 682-The Women-Stealers _. . . E. Matthew Hale. 683-On the Towing-Path $\ldots$.. $\quad R$. Wheelwright. 684-A Doubtful Lie .. .. .. Heywood Hardy. 685-Wishford BRIDGe ON THE WiLY RIVER: autumn manœuvres, I898, with the Northern Army James P. Beadle 


\section{GALLERY No. IX.}

\section{OIL PAINTINGS-(Nos. 686-942).}

686-The Sexton's Jest .. .. .. Nezuton Braby. 687-The Victor _. $\quad . \quad \ldots \quad$.. FrankJ. Torromé.

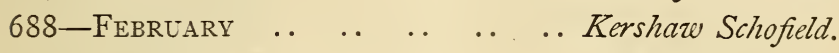

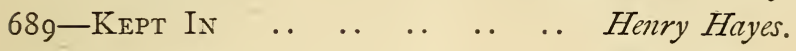
690-On the Top of Dolvan .. .. Hal Ludlow. 69I-Alfred Garth Jones, Esq. .. Frank Shelley. 692-Still Life .. $\quad . . \quad \ldots \quad \ldots \quad \ldots$ Harriette E. Grace. 693-Wallflowers A 694-Rook-Scaring .. . . . . Duncan H. Gosnell. 695-Tilling on the Nile Banks.. Frank Dean.

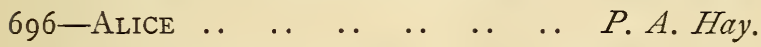
697-The Idler's Harvest .. Ama Alma-Tadema. 698-IN the Warith OF Summer

Days.. $\quad . . \quad$.. $\quad . . \quad$.. Joseph Farquharson. 699-Single Anemones _.. .. $\quad . . \quad$ J. Talbot Adams.

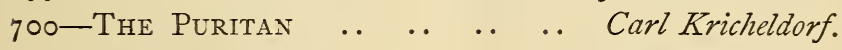
70I-Sweet-Williams .. $\quad . . \quad \ldots \quad . . \quad$ Mary $H$. Offord. 702-A Stream .. 703-Mrs. Byali Shaw .. .. .. Gerald Metcalfe. 
704-"GOOD NIGHT, DADDY"

705-The Old Stile.

706-Frozen OUT

707-A Market Garden

708-With ALL MY HearT

709-Home Fron Fishing ..

7 IO-A Lowland Lassie.
Joseph Clark.

H. Forbes Witherby. Claude Cardon. Sept. E. Scott. Maude Goodman. Albert Starling. R. Gemmell Hutchison. 7 I I-When the Heart is Young .. A. Ackland Hunt. 7I2-A Dutch Idyll...

7I3-Towards Evening: Purbeck 7 I 4 -A Challenge

7 I5-EdGe OF THE WOOD .. . .
7 I6-Laurels For THE Victor.. 7 7 - WILD RHODODENDRONS 7 I 8 -STARTLED

7 I 9 -Poppies

720 -Titania

72 I-September Sunshine..

722 -The Lady of Shalott

723-Spring-Time

724-Kaffir Women washing a
Tolt's Pan, Kimberley ..

725-The Esk Valley: Whitley

726 -Live Lobsters

727 -FRAMLINGHAM

...

728 -Voices of the Spring
.. Edith D. Brinton.

Ivystan Hetherington.

. J. FitzMarshall.

.. W. B. Lamond.

.. Thomas W. Cafe.

. Percival Gaskell.

.. Minnie Cormack.

. L. M. Keith.

.. Minnie Cormack.

. James $V$. Jelley.

Flora $M$. Lion.

Arthur A. Friedenson. Du

Agnes M. Cowieson.

.. Edwin Tindall.

. Ada Luker.

Frederic G. Cotman. Emma Sheppard. 
729-An Interior of Venice. Diploma work, deposited on his election as an Academician.. . . . . John S. Sargent, R.A.

730-Straight for the Gurs .. .. Donglas Adams.

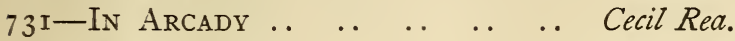

732-Market Day ..

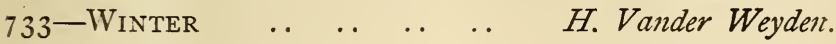

734-An Old FARM Pond.. .. .. George Ransom.

735-A Red-Coat .. .. .. .. Ada Luker.

736-Departing Ray of Sunshine:

Blythburgh

Frederic G. Cotman.

737-PREPARING FOR CONQUEST

738-AN AdaMless EdeN ..

739-HEAD OF A GIRL

740-BATHERS

74I-ON THE ALDE

742-Humming Birds .

743-Etretat _.

744-West Loch, Tarbert, N.B. .. J. H. Stevens.

745-Portrait of the Painter .. Frank C. Cowper,

746-A Spring Pastoral .. .. .. John Pedder.

747-Spring Flowers .. . . . . $\quad$ Christine R. Shand

748-In the ORChaRd .. .. .. Alfred H. Moore

749-FADING Light .. .. . . . . Walter Langley.

750-Mending Nets: Cantyre, N.B. F. Spenlove Spenlove.

75 I-The Village Inn .. .. Francis H. Newbery.

752-The Forsaken Nymph .. .. Dorothy Stanley.

753-Blackland's Royal Common, near Godalming $\quad . . \quad \ldots . \quad . . \quad$ T. W. Allen. 


\section{4 -Allegory}

755-"PAPILlon".
.. Augusto G. Stoppoloni. .. Robert W. Macbeth, A. 756-Birch and Bracken.. .. .. Samuel Gordon. 757-After a Long Day's Work George L. Harrison. 758-Portrait by Lamplight $P$. Elizabeth $F$. Thomas. 759-"ON BOKES FOR TO READ IS MY DELYTE"

760-The Stour, Sturry $76 \mathrm{I}$-Eventide 762 -Perros, Brittany.. 763-A Study Table..

764-Mill Dam on the Wey .. 765-A WeEdy CORNeR 766 - IN HAPPY WOODLAND 767 -On the Thames.. 768-The Sheldonian Theatre and Clanendon Building, Oxford 769-A Bursleet GirL 770 -Plain of Assisi... $77 \mathrm{I}$-MaGIC ..

772 -From the Cottage Garden 773-The Bathing Place.. 774-The Reading Lesson 775-The Harbour, St. Mary's, Scilly 776-A Dreamer of Dreams . 777-The Edge of the Forest 778 - HaY HaRvesT 779-VIOLETS 
780-Making a Rick .. $\quad . . \quad$.. . . George Clausen, A. $78 \mathrm{I}$-A Love Philtre .. .. .. $\quad$ E. Little.

782 -The Flower-Markets in Paris : choosing flowers .. $\quad$. $\quad$.. Stuart Hobkirk. 783 - "Be it EVER so humble, There's NO PLACE LIKE HOME" .. Beatrice Greenwood. 784-Autumn Roses .. .. .. . . R. Crafton Green. 785-Blue Summer : Sark .. .. .. Henry J. Ford.

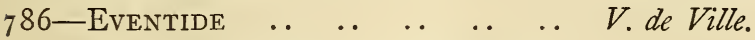
787-Old BoAT-House, Littlehampton G. Hillyard Swinstead. 788-Henry VII. Chapel, Westminster

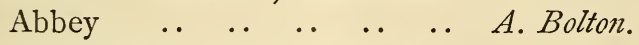

789-OH FOR That MORNing of THE Simple World .. .. Harry R. Mileham. 790-Near Charterhouse, Surrey .. T. W. Allen. 79I-The Sun's Last Gleam .. .. William Ashton. 792-MEAdow-SWEet .. $\quad . \quad$.. $\quad$ M. Ellen Edwards. 793-OfF to the Fishing: Scotch coast ..

Alfred S. Edward. 794-The Poor Man's Tea 795-Time the Physician.. 796-Sunlight 797-Primroses

798-IN Quiet SusseX 799-In Shakespeare's Country 800-LOITERERS 8or-The Smuggler's Daughter 8O2-Christmas Roses .. Arthur Ventnor. Eleanor F. Brickdale. H. Vander Weyden. .. Adela Seton-Tait. Grace E. Sainsbury. .. James Townshend.

.. W. Henry Gore. .. Harry Watson. Elizabeth Whitehead. 
803-SPRING-TIME

804-The Miller's Frau 805-DAY-DREAMS. .

Eisman Semenowsky.

806-IN THE ORCHARD

807 -Fishing-BOATs : near Venice 808-Summer Heat

809-The Bone of Contention

8Io-French Fishing-Boats in Tor-

QUAY HaRboUR

8I I-St. Mary's Church, from Canter-
bury Gate, Oxford
John Fulleylore.

8I 2-Roses

8i3-A REVERIE ..

8i 4-A Wonderful Tale..

8I 5-Consulting the Fly-Book ..
8i6-"East OF THE SUN and West

H. Macbeth-Raeburn.

Ernest Walbourn.

. Arthur Evershed.

.. William T. Wood.

.. Newton Braby.

Arthur J. Foster.

of the moON" .. .. H. W. B. Davis, R.A.

8i 7-A Bit of Hampstead, Middlesex FrederickJ. Sang. 8i8-A Pipe Opener... .. .. ...
8i 9-Evening in the Dock : Lime-

house.. 820 -Chloe .. $82 \mathrm{I}$ - "THE FLOWERS THAT BLOON IN

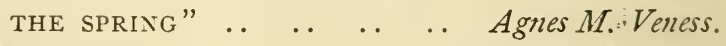
822-Mimosa.. $\quad . . \quad \ldots \quad . . \quad \ldots \quad$ Catherine $M$. Wood. 823-My Ain Fireside .. .. Valentine T. Garland. 824-The Sea Bank, Skegness.. .. Sidney Gardner. 825-A Dreamer.. .. 
826-Gipsies by a Strean .. Alex. Fuller Maitland. 827-Doubt and Misgiving .. $\quad . \quad W$. Cubitt Cooke. 828-In the Maytime .. .. .. Charles Collins. 829-The First-Born .. .. .. Thome Waite.

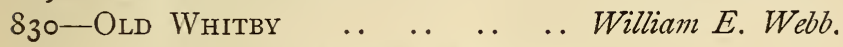
$83 \mathrm{i}$-The Canal of the Madonna dell' Orto, Venice... .. .. William Logsdail. 832-A Maiden of the Zuyder Zee Tom Browne. 833-Chrysanthenums Alfred Morgan. 834-Christmas Roses .. .. A. F. W. Hayward. 835-Mending Nets .. $. . \quad \ldots \quad . . \quad$ Edith Corbet.

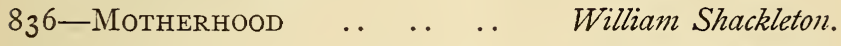

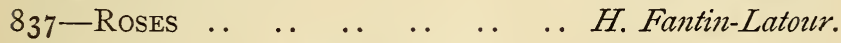
838-Portrait of a Man in Black George A. Storey, A. 839-A Trout-Stream _. .. $\quad B . W$. Leader, R.A. 840-Strict Injunctions .. .. George G. Kilburne. 84I-The Duke's High Dame.. .. Mary Y. Hunter. "As a tiring May, must I bind the shoon Of the Duke's High Dame, every day at dawning."

842-Mother Hubbard 843 -Roses

844-La DÉbutante

845-LONGING AND LOOKING 846 -SECRETS

847-EASTER EGGS

$848-H_{A D D O N}$, from the Meadows 849-Primroses 850 -TAKING IT EASY..
Edith Spraguee. E. Miller Fowler. ..J. Henry Henshall. .. C. Boucher James. .. Rowland Holyoake. . John Maddison. .. A. W. Redgate. .. Alfred Morgan. Valentine T. Garland. 
85 I-Seascape $\quad \ldots \quad \ldots \quad \ldots \quad \ldots \quad \ldots$ F. H. Michael. 852 -Open PAGes.. . . . . . . . Fred Spencer. 853-Lyminge Church, Kent .. .. Herbert E. Harley. 854 -Gossip . . 855-A Silent Prayer .. . . . Neroton Braby. 856 -PART OF RUIN OF THE CisTERCIAN NunNery, North

Berwick, N.B. .. .. . . . James Sant, R.A. 857-Queen of THE Night .. Benjamin Hanghton. 858-Mrs. Geoffrey Marks .. .. Shirley Fox. 859-Early SpriNg .. .. .. .John B. Wood. 860-A Fortune on the Throw .. John A. Lomax. 86I-Late Autumn : in a hill glen .. James Faed, jun. 862 -SEAFORD . . . . . . . . John Brett, A. 863-On Cannock Chase.. .. . . V. De Ville. 864 -February POSIES

...Louisa Aumonier. 865-The Madrip, Trevone .. .. John Brett, A. 866-Comfortably Kennelled Valentine T. Garland. 867 -SATURdAY Night Edward Stott. 868-The Pursuit of Alchymy .. Nezuton Braby. 869-Mary, the Mother of Jesus .. Jennie Moore. $870-$ The First SNOw - Adam E. Proctor. 87 I-"A SOldier EVER! ASSASSiN NEVER!" . . . . . . . .

John A. Lomax. 872-The Mill $\ldots \quad \ldots \quad \ldots \quad \ldots \quad \ldots \quad$ Walter Emsley. 873-Dolce far Niente .. .. Valentine T. Garland. 874-GREY DAY .. .. . . . . . . Richard Short. 875 -Trewoof .. . . . . . Stanhope A. Forbes, A. 
876-In the Valley 877 -FRUIT TREES
Walter Robinson. Thomas E. Francis.

878-"The thoughts of youth ARE LONG, LONG THOUGHTS".. .. Walter Urwick.

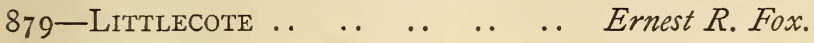
880-A Shady Corner on a DartMOOR FARM 881-William Sparks, EsQ. .. ..Rowlland Holyoake. 882-The Top of the Village .. Herbert S. Percy. 883 - "AND NOW THE STORM BLAST CAME, AND HE WAS TYRANNOUS AND STRONG" 884-A SaUCy Girl .. 885-Invalided Home .. .. .. George A. Holmes. 886-Through the Woods in Winter Robert S. Brutey. 887 -PRO FIDE..$\quad$.. $\quad . . \quad$.. Frederick D. Walenn. 888-Among the Wild Hyacinths:

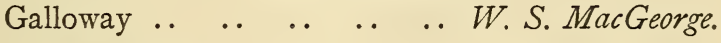
889-Our Play-Room .. $\quad$.. $\quad$.. $\quad$.. Henriette Ronner. 890-Newtrain Bay, Cornwall .. .. John Brett, A. 891-EAST Wind : Cardiff .. .. .. Richard Short. 892-Sunshine Days .. $\quad . . \quad$.. $\quad$.. James $V$. Jelley.

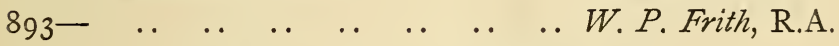

"She gives a side glance and looks down, Beware, beware.

Trust her not,

She is fooling thee !"

894-Le Chapeau de Paille .. .. Eyre Crowe, A. $895-F_{\text {RUIT }}$.. 
896-News from the Front .. .. Hugh Carter. 897-A Limpid Mirror .. .. .. George A. Gaskell. 898-A Woodland Princess .. Jennie Brownscombe. 899-Early Morning: Houghton,

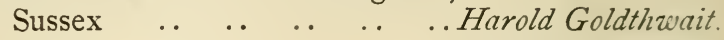
900-A Little Duke.. .. .. Charles T. Garland.

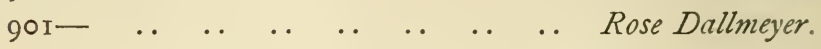

"The whispering waves were all asleep, The clouds had gone to play, And on the trees and on the deep The smile of heaven lay."

902-A WATER-Mill .. $\quad . \quad \ldots \quad \ldots \quad$ Walter Robinson. 903-My Custom Always, in the after-

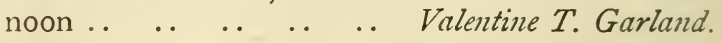
904-The Wind Among the Barley John Brett, A. 905-An Autumn Evening .. .. Fred Hall. 906-Our Heart's Delight .. .. Maude Goodman. 907-Spring Flowers.. .. .. .. Val Davis. 908-Cupid .. 909-Abinger Mill-Pond .. .. .. Frank Walton. 9I0-FOREBODINGS .. .. ...Duddingstone Herdman. 9i I-Near Dunbar, North Britain .. James Sant, R.A. 9i2-The Family of Nazareth Auguisto G. Stoppoloni. 9i3-The Lock Meadow .. .. John M. Macintosh. 9i4-The Maid of Athens Marg. Murray Cookesley. 9I5-Clearing up After Rain .. James Faed, jun. 9I6-TRIUMPH

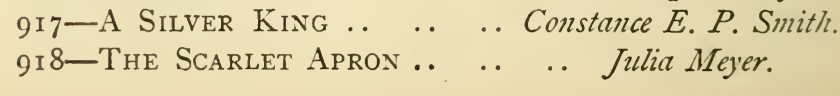
L. Campbell Taylor. 
9I9-The Top of the Hill 920-MARSHLAND, near Lewes 92 I-INTERESTING News 922-START BAY 923-Ploughing in the Fens 924-The WaLK by the River 925-BERWICK-ON-TwEED 926 -Buying for the Sultan .. 927-Sheep-Milking: Walcheren 928-IN Sight 929-A Duet

930-The Goat-Herd. 93 I-The Song 932-The FÊTe Day 933-MOONRISE 934-Gamblers
Charles Western. Mary Harding. Jonathan Pratt. Bryan Hook. Percy Haddan. Alice Fanner. James Wallace. Dudley Hardy. Mary Stormont. F. Percy Wild. Carl Schloesser. 935-"A MAN CONVINCED AGAINST HIS WILL, IS OF THE SAME OPINION

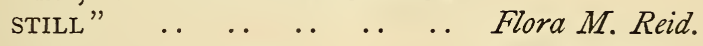

936-A Note of Summer .. .. . . Owen Dalziel. 937-In Possession $\ldots$.. 938-The Bargain .. $\quad . . \quad \ldots \quad$ L. Campbell Taylor.

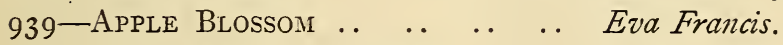
940-The Garden of Sleep .. .. A. W. Bayes. 94I-A Flaw in the Title .. Charles E. Richardson. 942-After the Dance .. .. Eisman Semenowsky. 


\section{GALLERY No. $\mathrm{X}$.}

OIL PAINTINGS-(Nos. 943-1020).

943-"DAFFodils, THAT COME Before THE SWALLOW DARES AND TAKES THE IVINDS OF MARCH WITH Beauty"

944-Penton Hook on the Thames

Alfred A. Glendening.

945-COMING IN ON THE FiRST OF The Tide ..

946-" TO LIFE AND TOIL, THE BREATH

OF NATURE LENDS A TOUCH OF

COLOUR" .. .. . . Charles $M$. Q. Orchardson.

947-The Quay Side: Rouen .. .. Terrick Williams. 948-Motherless.. . . . . Norman M. Macdongall. 949-Mrs. John Morley .. .. .. T. Blake Wirgman. 950-The Silent Prayer .. .. . . Samuel E. Waller. 95I-Deus Arcitenens .. .. ...Spottiswood Duthie. 952-In the Suffolk Marshes Alfred J. Munnings. 953-Miss Rita Maclachlan .. .. P. A. Hay. 954-A Rustic Mirror .. .. .. Edward H. Fahey. 
$955-\mathrm{THE}$ Евв

"But such a tide as moving seems asleep, Too full for sound and foam,

When that which drew from out the boundless deep Turns again home."-Tennyson.

956-Routed : Boers retreating .. .. John Charlton. 957-The Billiard Players .. .. Hon. John Collier. 958-Bank Holiday, Hampstead Heath Maynard Brown. 959-Robert Dudley, Esq. .. .. Ambrose Dudley. 960-At the Starting Post .. .. Mary Cameron. 96I-In the Cold Blast .. .. .. Robert W. Allan. 962 -In the Golden Days .. .. Hugh G. Riviere. 963-A Student OF the Azhar Mosque, Cairo.. $\quad . . \quad$.. $\quad .$. Walter C. Horsley. 964-The Frippery Dealer .. .. Richard S. James. 965-A Cottage Garden .. .. .. James Watson. 966-Where Untroubled Peace and Concord Dwell .. .. .. Rose Welby. 967-The Gardener's Daughter Mary C. Palethorpe. 968-After Supper .. 969-Entrance to King Edward's

Room, Berkeley Castle .. .. Frank C. King. 970-The Day's Work Done .. .. Arthur Lemon. 9
9
9
9

97

The Road of Love 973

974 -

975-WidOWED

. $\quad \ldots \quad \ldots$

Marg. Murray Cookesley. 
976-Evening: early spring .. .. George T. Rope. 977-Miramar Roses .. $\quad . \quad$.. $\quad$.. $\quad$ A. Miles Albert. 978- Where the Wild Flowers grow

Florence FitzGerald.

979-"A LOVING Psyche Who LOSES SIGHT OF LOVE."-Mrs. Barrett Browning .. $\quad . . \quad \ldots \quad . . \quad \ldots \quad M$. Ridley Corbet. 980-The Horse-Thrasher .. .. Ralph Hedley.

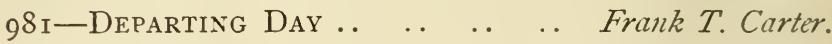
982-Portrait of a Lady.. .. . . Cecilia Beaux. 983-Dinner-Time .. $\quad . . \quad \ldots \quad . . \quad$ Leghe Suthers. 984-Thomas IVall Buckley, Esq... Walter C. Horsley. 985-Spring: an allegory .. .. .. Arthur T. Nowell.

"Now dreamy earth, from Winter's sleep aroused, Stirs drowsily when Spring with gentle voice, Cries wake! awake! for Summer comes apace, And all the groves are filled with singing birds." - Anon. 986-The Ladies of Arthurian

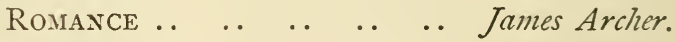

" Morgan le Fay and the Lady of the Lake perform an incantation and raise the Spirit of the Lake with the mystic sword Excalibur."

987 -WOOD-GATHERERS

.. .

Florence Fitz Gerald. 988- Through Dutch Meadows . SOFTLY, Frour RUGGED MOUNTAIN SIDES" 990-How He WoN the V.C. .. .. Gilbert S. Wright. 
99I-"Cone Up, Blossom! Come Up, DaIsY! COME UP, BESS, With

THE SWISHing TaIL" .. Margaret A. Heath.

992-Love will Triumph .. $\quad . . \quad \ldots \quad$ C. Haigh-Wood.

"Love may sink by slow decay,

But by sudden wrench, believe not

Hearts can thus be torn away."

993-Lady Jane Beaufort and King

James I. of Scotland .. .. J. Doyle Penrose.

"And therewith cast I down my eyes again,

And walking as I saw beneath the tower.

* * * * * *

The fairest and the freshest youthful flower,

That ere I saw methought before that hour."

'The King's Quhair.'

994-An Old ORChaRd: Weston Mills,

near Plymouth .. $\quad$.. $\quad$.. $\quad$.. $\quad$ George Cartlidge.

995-At Nazareth $\ldots$..

"Yea, a sword shall pierce through thy own soul also."-St. Luke ii. 35.

996-Mrs. Clowes _.

997-Attelage Basque .. .. Stanhope A. Forbes, A. 998-Autumn Sunrise: Connemara.. Charles Pettafor. 999-The Lily Garden .. . . . Mary Harding. 1000-A Portrait _. iooi-A Devonshire Village .. .. W. Follen Bishop. iOO2-An Eighteenth Century

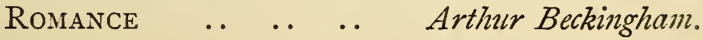


I003-"WITHIN THE BRANCHING SHADE

OF REVERIE."-D. G. Rossetti. Val Havers.

io04-Portrait of a Lady .. C. M. Q. Orchardson.

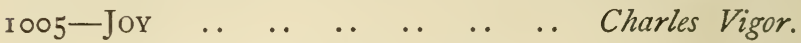

roo6-Life's Labour Well Done .. Ernest Normand. io07-The Trent at Wilford .. A. W. Redgate. ioo8-After Play .. .. .. .. William Bramley. IOO9-The Flight OF THE French THROUGH THE TOWN OF VITTORIA : Peninsular War.. .. Robert Hillingford. roro-Old DEFENDERS : assembling of H.M. Yeomen Warders for the Inspection on Tower Green... Fred Roe. rori-A Heavy LoAd: Isle of Marken Tom Browne. ror 2-Lilian _. ror 3-Miss Frances Cockerell ..Frederic C. Mulock. ior4-Mid Atlantic .. $\quad . \quad \ldots \quad \ldots$. Ayerst Ingram. IOI5-The DReam OF The KNight Errant .. ioi6-The Good Samaritan .. .. William Small. ior7-After Heat of Day .. .. Arnesby Brown. ror8-Miss De Chair .. ..

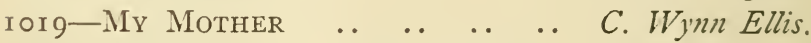
rozo-Banks of the Arun, Sussex.. José Weiss. 


\section{GALLERY No. XI.}

\section{OIL PAINTINGS-(Nos. 1021-1090).}

IO2 I-The First of the EBb .. .. Robert Gallon. IO22-Grandfather's Pets .. .. Emest H. Rigg. I023-The Bathers .. .. . . . . Mark Fisher. ro24-Mrs. Jules de Meray .. Solomon J. Solomon, A. IO25-"ERE THE FIRE IN THE WEST
DIES OUT"
Duncan H. Gosnell.

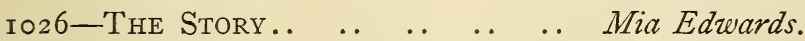
IO27-A Convert .. .. .. Frederick D. Walenn. IO28-CORnflowers .. io29-A Panel of ARum Lilies .. Helen Franck. IO30-ORdered South .. $\quad . . \quad$.. Sydney Muschamp. io3 I-West Street, Corfe .. .. James S. Hill. I032-A Lock on the OUSE .. F. Stuart Richardson. ro33-Mr. Alfred Gibson. Presentation Portrait.. .. $\quad . . \quad$.. Herbert A. Olivier. IO34- "THE WAYS OF MAN ARE PASSING STRANGE" $\quad$. i035-The Princess Demidoff ..Benjamin Constant. io36-Magellan in the Straits .. J. Fraser. I037-Cribbage 
IO38-"THE OCEAN BEATS AGAINST THE STERN DUMB SHORE THE STORMY PASSION OF ITS MIGHTY

HEART" .. I039-SPORT AND SPIRIT .. IO40-WOOL FOR THE CARGO-BOAT : distant view of Cairo .. Fredk. Goodall, R.A. io4i-Lady Colebrooke .. .. . . Benjamin Constant. IO42-A Flying SQuadron of the

Old School .. $\quad . . \quad . . \quad$ Thomas Somerscaies.

I043-The Death of Ladas, the Greek runner, who died when receiving the crown of victory in the Temple at Olympia .. George Murray.

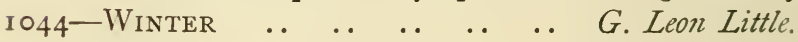
I045-Rev. W. W. Skeat, Litt.D. .. Charles E. Brock. io46-Prometheus Consoled by The

Spirits of the Earth .. George S. Watson.

"Prometheus. How fair these air-borne shapes! and yet I feel Most vain all hope but love..." Shelley's 'Prometheus Unbound.'

I047-Left in Charge .. .. . . Philip E. Stretton. I048-Mrs. Banfield.. .. .. Bernard F. Gribble. io49-Mr. Gladstone Editing the WORKS OF Bishop BUTLER

J. McLure Hamilton. io50-The Song went to her Heart $M$. E. Kindon. I05I-The Plague Ship of The

Yellow Death .. .. .. Bernard F. Gribble. I052-Sylvia : a portrait .. .. .. Henry L. Dell. 
I053-Gathering Blackberries .. James Charles. I054-A. F. Walter, EsQ. .. .. Hugh G. Riviere. i055-Gone Away _. I056-HonewaRd.. .. $\quad . . \quad$.. $\quad$.. Rowland H. Hill. i057-Through the Beeches .. .. Adrian Stokes.

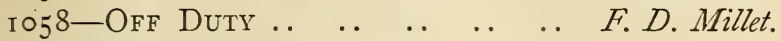
I059-The Silent Requiem: Anno Domini I 900 .. $\quad . . \quad$.. $\quad .$. Jessie Macgregor. io6o-General Gordon Quelling a Riot at Darfur .. $\quad . . \quad$.. Stanley Berkeley. He rode almost alone into a camp of rebellious slavehunters, and by sheer force of will quelled the rebellion. IO6I-Fishers of the Zuyder ZeE $F$. Stuart Richardson. I062-Dr. Henry Rayner .. .. Henry S. Tukej, A. io63-A Careful Selection .. .. J. Michael Brown. io64-Mrs. Gerald Arbuthnot .. Mark Milbanke.

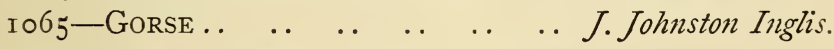
IO66-ACROSS THE STRAITS FRONI Mona's IsLe ..

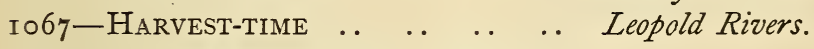
IO68-J. LORIMER WARDEN, rough rider Herman G. Herkomer. io69-Autumn on the Wye .. .. C. E. Johnson. io70-Hon. Mrs. Stuart Bouverie.. Emile Wauters. IO7I-Wind Against Tide: coast of

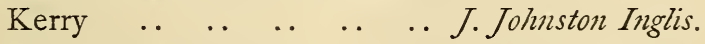
I072-Sunshine and Shade .. .. James E. Grace. io73-The Lost Sheep .. .. .. Alfred U. Soord.

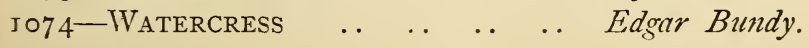


I075-The Lady Mayoress (Lady

Newton). Presentation Por-

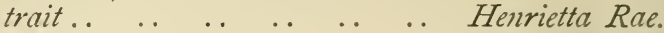

I076-"Mothers of OUR Kings TTO BE" Edwin Donglas. I077-"GREEN FIELDS AND HAPPY

GROVES, WHERE FLOCKS HAVE

TOOK Delight."-Blake .. Annette Elias.

Iо78-The River .. .. .. Hon. Walter J. James. io79-An Officer of Hussars.. Daniel A. Wehrschmidt. IO80-Where the SEA-EgG Flanies

ON THE CORAL .. .. $\quad$.. J. Fraser.

I08 I - PhYLLIS, daughter of Edward W.

Meyerstein, Esq. .. .. Georæe A. Storey, A.

IO82-The APPRENTICE'S ENForCED

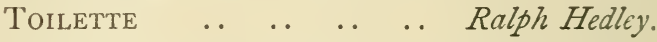

"Disobedient apprentices were first in open courte made exemplary by shortning their haire and taking from their clothes superfluous ribboning."

i083-The Mill-Stream .. $\quad . \quad$. $\quad$ Edwin Nichol. I084-The Old Mill.. .. .. . .Ernest P. Bucknall. I085-A Mountain Path .. .. .. James Faed, junr. io86-Our True Friends.. .. .. George A. Holmes. io87-Kittry Knowles .. .. .. Monat Loudan. io88-A Silvery Afternoon in June $\mathrm{Wm}$. Greaves. ro89-Ticklish .. I090- "HARK ваCK" .. 


\section{WATER COLOUR ROOM.}

WATER COLOURS, ENAMELS, AND MINIATURES.

WATER COLOURS-(Nos. 1091-1355).

iogi-A Study of a Man's Head .. Ethel M. Willis. IO92-Thick Weather .. .. .. Harold Knight. ro93-The Man in the Street .. Albert Morrow. io94-A Street in Dinax .. Herbert G. Ibberson. ro95-A Windy Autumin Day, Old Boston .. Iog6-A Soldier's Daughter .. William B. Bennett. IO97- "THE TREES BEGAN TO WHISPER AND THE WINDS BEGAN TO ROLL IN THE WILD MARCH MORNing." - Temyson .. .. Sylvester Stamard. IO98-November: "And the year, on the earth her deathbed, in a shroud of leaves dead, is

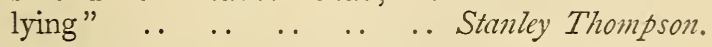
io99-Kentmore Hall, Westmorland Arthur Tucker. inoo-The Spring-Tine of Life .. Robert Meyerheim.

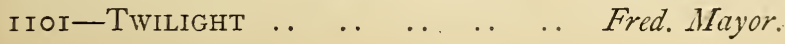


I IO2-A Shepherdess OF the PIreNEES

Elizabeth Forbes.

I IO3-Tigers

i io4-The Tranquil Light of Rosy MORN

I I05-IN the Valley of Chevreuse
I IO6-The River Near Aberystwith, North Wales

.. .. C. Sabon Laurent. iro7-A Surrey Common .. $\quad . . \quad$.. Sutton Palmer. i io8-Fari at West Yalding, Kent Mary S. Hagarty. i ro9-In Longleat Woods .. .. Alfred Parsons, A.

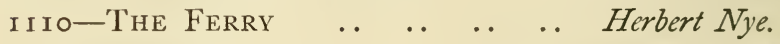
i il i-The Old Chair .. . . William B. Bennett. i I 2 -The Canal at St. Valery-SurSomme .. im i3-Richnond Park .. .. Augustus $W$. Weedon. i i 4-Falls of the Garvie, Suther-

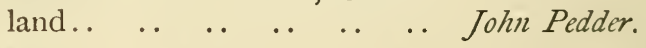

III5-"WINE IS A MELTED RUBY AND THE CUP IS THE MINE THERE-

of."-Omar Khayyàm .. Sidney H. Meteyard. i i 6-Harvest-Time .. .. .. .. Ernest G. Beach. I I 7-Crabbed Age and Youth CaN-

not Live Together .. .. Henry $M$. Rheam. i i 8-The Fall of the Leaf.. .. Erskine E. Nicol. i i 9-The Trusting-Lane .. .. Sylvester Stannard.

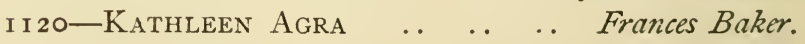
I 2 I-Beer Head, South Devon, sunset Fritz Althaus. 
II22-NoRian LaCEMAKER
II23-AN EAST COAST Fishing-

$$
\text { Village .. }
$$

ir 24-Evening Light $\quad . \quad$.. $\quad$.. George Marks.

i I25-Selhair Mill .. $\quad . . \quad$.. $\quad$ Ernest P. Bucknall.

ir 26-A Well in Brittany .. .. John Parker.

in 27-A Troublesome Family.. .. Henry Bailey.

i 2 28-The Children's Hour .. .. Patty T. Johnson.

II29-The Fringe of Dartuioor .. Frederick Shelley.

i i 30-Chesnut $\ldots$.

I I3 I-ElSA BaRney $\ldots$..

II32-The Power aNd Wealth of

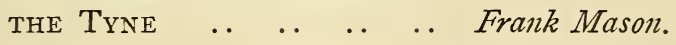

$\left.\begin{array}{l}\text { ir33- } \\ \text { I } 34- \\ \text { i } 35-\end{array}\right\} \begin{gathered}\text { The Poetry } \\ \text { of Music: }\end{gathered}\left\{\begin{array}{l}\text { Orpheus } \\ \text { Homer } \\ \text { St. Cecilia }\end{array}\right\}$

i 36 -The Barber's Shop, Edam,

North Holland .. .. ..W. H. C. Groome.

i 37 -The Harvest-Field .. . . . Robert Hume.

i i38-The Old Net-Maker $\ldots \quad \ldots W . H . C$. Groome.

ir 39-Isola San Giuliano Sir E.J. Poynter, P.R.A.

I i 40-Breakfast-Time .. .. ... Charles $E$. Wilson.

I I II-BeC DU Nez, Sark .. .. .. Frank Walton.

i I 42 -Sheung-mun-Tai Street, Canton

Norman H. Hardy.

in43-On the Road to Ladysmith Percy Dixon. 
I I 44-Roses .

William J. Muckley.

i i 45-The Countess of WARiwick .. Ellis Roberts. in 46 -The Moping Heron - Hood's 'Haunted House' .. .. .. Joseph Dakin. i 47-Near Danbury, Essex .. .. Leopold Rivers. i I 48-The Cathedral Rocks, Mullion Herbert $K$. Rooke. I I 49-Spring-Time IN A Surrey FIELD : cow-parsley $\quad . . \quad \ldots \quad$ A. Marrable. i 50-A Rainy Day .. inji-A West Country Trout-

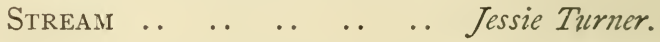
i 52 -Making a Ball for Pussy .. Nellie Sansom. i 53-The Christmas Steps, Bristol George M. Henton. in 54-After the Bath .. .. .. Hector Caffier. I I55-Henley, Sussex _. .. .. A. R. Quinton. i i 56-Fancyland $\quad . \quad$.

"When the soul doth forwards bend, And dream the sweet world hath no end."

ir 57-Toll and Play.. $\quad . . \quad \ldots \quad \ldots$ Patty T. Johnson. i I58-On the Wrong Side .. .. Walter Bothams. II59-“IN SPRING A YOUNG MAN'S FANCY LIGHTLY TURNS TO thoughts of Love" .. .. Tom Browne.

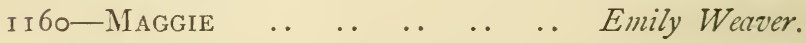
in 6i-The Old Castle, St. Mawes.. C. Napier Hemy, A. i i62-Captured .. $\quad . . \quad \ldots \quad \ldots \quad$.. J. Henry Drage.

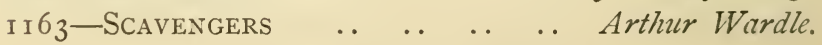


1900.] WATER COLOUR ROOM.

I 64-Miss VANDERBILT-WaCKERManN
AS
"Pallas Athene".
Ellis Roberts.

in65-A Few Simples _. .. ..Robert A. Dawson. in66-The Glyders, from Ogwen .. John C. Salmon. i 67-Pirbright Common, Surrey .. John H. Dearle. II68-By THE Edge OF THE CoRN-

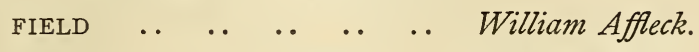

in69-A Look into the Future .. Joseph $W$. Forster.

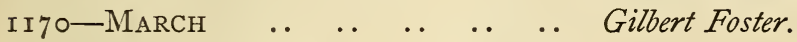

II7 I-SPRING Driving OUT Winter: design for wall decoration .. Fred Appleyard.

I 72-When Little Ones Grow Weary

I 73-BlackDown, from Henley Hill,

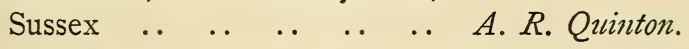

I 74-White Chrysanthemums .. Edith $I$. Barrow. I 75-An Autumn Moonrise .. .. Alfred R. Baker.

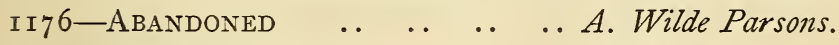
in77-Their Morning Bath .. .. A. M. Rossi. I 78 -Low-Water TARN IN THE Old MAN, Coniston _.. .. .. Isaac Cooke. II79- "FAR FROM THE MADDING CROWD" ..

II80-"WHERE RURAL FAYS AND FAIRIES DWELL" .. .. .. Walter J. Morgan.

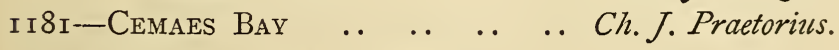
in82-The Little Fishing-Boats C. Napier Hemy, A. 
I 83 -RhoDODENDRONS

I 84 -Kynance, Cornwall

I I 85-Devotion

I 86 - When SuMMer
FLOWN

i 87 -Under the Awning

in 88-The Gentle Art

ir 89-An Autumn Garden

II90-SPRING is CoMING

i I9I-The Last Gleam

ir 92-Hayle Bar, Cornwall

i 93-Lee Manor Lane

I I 94-Where the Dead Sleep : Lower
Gertrude E. Offord.

G. Spawton Catlow. Henry Ryland.

ARE

Albert Kinsley.

. Frederick W. Jackson.

Innes Fripp.

.. Richard Wane.

.. E. A. Langdon.

.. John J. Willson.

Charles S. Mottram.

.. Charles S. AMottram.

.. .. Alfred East, A.

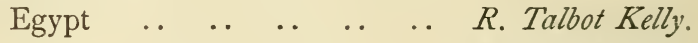

i i 95-The Eagle's Stronghold

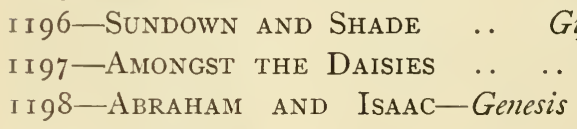

xxii. II, I 2 .. $\quad$. $\quad$.. $\quad$.. George Murray.

II99-A Grey Day: West Highlands Hubert Coutts.

I 200 -ON THE Wey $\ldots$.. I 20 I-A Millstream .. $\quad . . \quad$.. .. Leonard Fosbrooke.

I 202-Ploughing: on the borders of

Dartmoor . . . . . . . . Richard Hoskin.

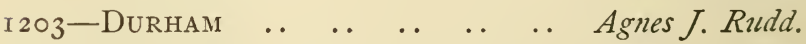

I204-A Storiy Day: Loch Laggan Ernest E. Briggs.

i 205-Normandy Cottage.. . . . . Aston Knight. 
I206-"SURGE AFTER SURGE WITH HOLLOW BOSOMED ROAR,

PLUNGES AND BREAKS" .. George Cockram.

I207-The Morning of Life .. William P. Cornish.

I 208 - The LAST STACK : harvesting, near Bradford.. .. . . . . Thomas Bushby.

I209-A BREEZY UPLAND .. .. .. Arthur Tucker.

I 2 IO-A SurRey LANDSCAPE . . . George Marks. I 2 I -ChildhoOd's HAPPy DAys .. William Affleck. I2I2-WILD POPPIES IN THE AR-

DENNES .. ..... .. Howard G. Stormont.

I 2 I 3 - Conway MaRsh, the 3rd Lanca-

shire Volunteer Fusiliers in

camp $\quad . \quad \ldots \quad \ldots \quad \ldots \quad \ldots J$ John C. Salmon.

I 2 I4-A FOREST WAIF $\quad . \quad \ldots \quad$.. Fred. Mercer.

i215-A Western Silver Sea .. Charles S. Mottram. I2I6- $\quad \ldots \quad \ldots \quad \ldots \quad \ldots \quad \ldots \quad \ldots \quad \ldots$ Lexden L. Pocock.

"Kilmeny looked up with a lovely grace, But nae smile was seen on Kilmeny's face ;

For Kilmeny had been she knew not where, And Kilmeny had seen what she could not declare."

The Ettrick Shepherd.

I 2 I7- "Caller herrin" ". . . Leonard A. Pownall. I 2 I 8-Oporto $\quad \ldots \quad \ldots \quad \ldots \quad \ldots \quad$ C. Napier Hemy, A. I 2 I9-Street in Algiers .. . . . . Reginald Barrett. I220-ThE BRoOK .. .. $\quad \ldots \quad$.. William Affleck. I 22 I-William Maitland, Esq. . . Alfred U. Soord. I 222 -RHODODENDRONS $\quad . \quad \ldots \quad$. . George Marks. 
I 223 - On the Hill-Side $\ldots$.. $\quad .$. Alfred $H$. Moore. I224-ThE END OF THE WINTER : Thusis .. $\quad$. $\quad$.. $\quad$.. Margaret F. Ravenhill. i 225-The Way to the Farm.. Benjamin D. Sigmund. I 226 -Julie . I 227 -After the Day's wOrk .. .. Samul Towers. I 228 - Harvest of the Sea .. .. Hubert Coop. I229-Winter in Holland .. .. Aston Knight. I 230-The Stour Valley, Hampshire Noel Smith. I 23 I-Boscombe Gardens .. .. . .. Frank G. Mart. I232-A Quiet Spot .. I233-In the Forest of Arden $\ldots$ James $T$. Watts. I 234-Lady Weston's Walk, Sutton Park, Guildford .. .. .. Thomas H. Hunn. I 235-"WHERE WILD IN THE WOODLANDS THE PRIMROSES BLOW"

Elizabeth $M$. Chettle. I236-On the Surrey Downs... .. Norman Graham. i 237 -Spring-Time $\quad . \quad$.. $\quad$.. $\quad$..Joseph Kirkpatrick. I 238 - "When Greek Meets Greek"

Charles J. Adams. i 239-A September Evening .. .. Frederick Shelley. i240-Twenty Years After .. .. P. A. Hay. I 24I-A Dewy Morning .. $\quad . . \quad$ E. Dorothy Willson.

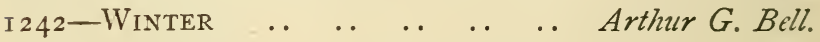
I 243-"For King and Fatherland" : an incident in the German Struggle for Liberty .. .. John H. F. Bacon. 
I244-The Shelter on the Moor.. Arthur G. Bell.

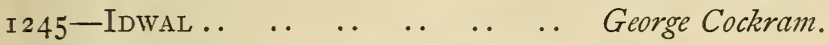
I 246-Sea Mists: Spanish Head, Isle of Man .. I 247-The Valley of the Severn.. Frank Porter. I248-The Resuscitation OF St. WinEFride $\quad . \quad$. $\quad$. . . . Winefride Freeman.

St. Winefride, having been murdered by Caradoc, was resuscitated at the prayer of St. Bruno.

I 249-The Horse-trough .. $\quad . \quad$. . Charles Low.

(On the Screen.)

I250-The Duck-pond A $\quad \ldots \quad$.. $\quad$ C. Duassut.

I25I-Mid Chestnut Shade .. Charles H. Baldwyn. I252-A Musketeer .. I 253-Phyllis $\quad . \quad \ldots \quad \ldots \quad \ldots \quad$ George H. Edwards. I254-St. Mary's, Guildford .. .. Ernest Spence. I255-From the Front $\ldots$.. $\ldots$ A. D. Bastin. I 256-VIEW of Richmond, Yorkshire

George H. Edwards I257-Old Willow at Slifkev, Norfolk .. I258-Chalfont St. Giles .. .. Louisa M. Watts. I 259-Tea in Kensington Gardens Jeannie Drysdale. I260-So NEAR, AND yet so FAR .. Gordon Browne.

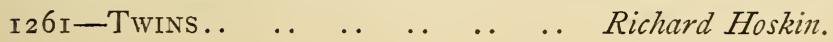


I 262-Witley, Surrey .. $\quad . \quad \ldots \quad \ldots \quad$ G. Lewis Luker. I263-A Water Picnic .. .. .. Shirley Fox. i264-A Cottage at Witley .. .. $\quad$ E. R. White. I 265 -Landscape .. $\quad \ldots \quad \ldots \quad \ldots \quad \ldots \quad$ F. H. Michael. I266-EDwARD, son of E. M. Bovill,

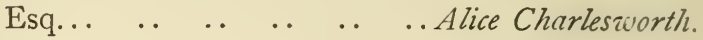
I 267 -The Banks of the Yeam .. Ida Betts. I268-A Common : Midhurst .. .. Fred. Williamson. i269-The Dawn of Spring .. . A Arthur E. Strutt. I 270 - The Blissful Cloud of Summer

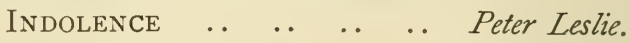

I 27 I-Sunshine and Shadow .. ..Charles J. Adams. I272-On the ARUN .. $\quad . \quad \ldots \quad$.. Herbert E. Evans. I273-Putting down Eel-Baskets Henry R. Robertson. I 274-Charing Cross.. $\quad . . \quad \ldots \quad \ldots$ Fred. E. J. Goff. I275-A Meadow Queen .. .. .. Lucien Davis.

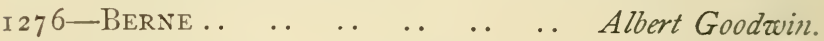

I277-The Ending of the Day .. C. Duassut. I278-Portrait OF A LAdy .. ...Margaret Dockerill. i 279-Tranquillity .. i280-A Halt by the Wayside .. Edith M. Harms. i28i-IVinter in Surrey .. . . . . Wilfrid Ball. i 282 -La Madonna di Mestre Henry R. Robertson. I283-London, from Tower Bridge .. Fred. E. J. Goff. i 284-Poppies $\quad . \quad$. I 285 -VIOLET, daughter of E. M. Bovill,

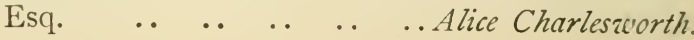




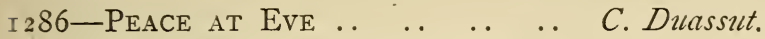

i 287 - On the Coast at Morsaline,

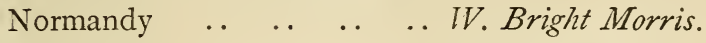

I288-MaRshland $\quad . \quad$. .

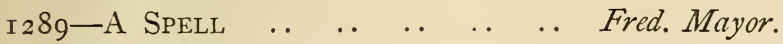

I290-Fish Sale on the Quay .. May Furniss.

I29I-The Garden in June .. Catherine Barnard.

I292-Le Béguinage, Bruges .. . . Mary Stormont.

I 293-Near Old Sarum $\ldots$.. $\quad$. .

I294-Silver And Gold .. $\ldots$.. $\quad$ George Hughes.

I 295-Walcheren Shrimp-Boats ..Charles J. Watson. I296-Between the Sun and Moon

UPON THE SHORE .. $\quad . . \quad$.. Thomas Crane.

i 297-The Mill-Field, Hornchurch L. Burleigh Bruhl. I 298-The Osier-Bed.. $\quad . . \quad \ldots \quad$.. Henry T. Jarman. I 299-The Watchers..

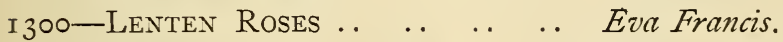
I 301 -Ponies : frosty morning .. .. Arthur E. Fisher. i 302 -The Loggia dei Lanzi, Florence E. Wake Cook. I 303-The Walled Garden, Sutton Place, Guildford .. .. .. Thomas H. Hunn. i 304-Spring-time _. $\quad \ldots \quad \ldots \quad$ R. Beatrice L. Smith. I 305-Tower OF ChURch OF St. Michael, Bassishaw, lately destroyed .. .. $\quad$.. $\quad$.. $\quad$ Philip Norman.

I 306-BABY : a portrait .. .. ...Mary L. Harcourt. 
I 307 -Fleet Street

I308-The Babes in the Wood

I 309 -ON Whitley SaNdS..

I3IO-JACK AND JILL..

I3II-" IF
AT FIRST YOU DON'T
Fred. E. J. Goff. Winifred Stamp. J. Wait Clark. Amy Scott.

SUCCEED"

i3i2-The Vale of the Severn Ernest $A$. Chadwick. i 3 3-Harmony 3 .. $\quad$. i3i4-A Bit of Old Lisieux, Nor-

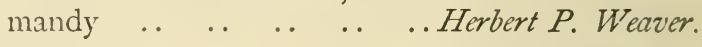
I3I5-Harvest .. .. i3 6-A Water Highway .. .. .. Charles E. Flower. I3I7- "A SIMPLE ChILD, THAT LightLY DRAWS ITS BREATH" .. .. Gideon Fidler. i3i8-The Goats' Stable.. .. .. Blanche Baker.

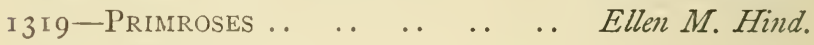
I320- "HiP'RA! HERE'S THE PICTURE MAN" $\quad$.

I32I-A Hedgerow .. I322-Cortina, Tyrol: spring-time ..Arthur W. Knight. I323-Market-Day $\ldots$.. $\quad . . \quad \ldots \quad A$. Verey.

I324-Cottage Garden, Clandon, Guildford .. $\quad . \quad$.. ..Thomas H. Hunn. i 325-Miss Jessie H. Jones .. .. Peter Leslie. I326-The Path from the Shore.. H.J. Johnstone. I327-A Backwater on the Thames

Benjamin D. Sigmund.

I 328 - A Chrysanthemum Garden .. John H. Ty'son. 
i329-Mercato Vecchio, Florence.. Mabel A. Butter. I330-Mushrooms .. $\quad . . \quad \ldots \quad$ William C. Ricketts. i33I-The First Easter Morn: "What thou sawest, Mary, say, As thou wentest on the way" Henry Ryland. i332-A Surrey Common .. $\quad . . \quad$.. Sutton Palmer. i333-One of the Family .. William A. Menzies. I334-A Hampshire Homestead .. Alfred R. Baker.

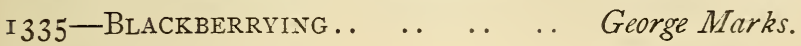
I336-SPRING _. I337-The Terrace, Losely .. . . Thomas H. Hunn. I338-A Silver Catch .. .. .. Edith F. Grey. I339-The Old Path through the

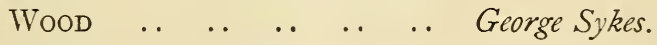
I340-Gatehouse AND BRIDGe, Sandwich ..

I34I-Autumn Glow .. $\quad . . \quad \ldots \quad$.. George Marks.

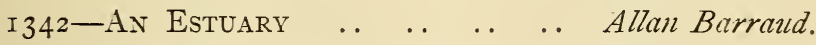
I343-News frour the Front .. .. A. Hugh Fisher. I 344-Cottages, St. Minver, North

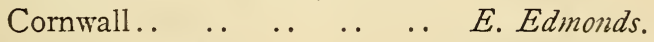
I345-An Old Line-Kiln.. .. .. George Marks. I 346-A School-GirL.. $\quad \ldots \quad$.. $\quad$.. Mary Marks. I347-Shells of the Sea... .. Alfred B. Bamford. I 348 - ThE WAKE OF THE S.S. 'Valetta' in the Great Australian Bight $\quad$. A. H. Hallam Murray. 
i349-A Summer's Moon .. $\quad . . \quad$.. James L. Browne. I350-A Cloudy Day.. $\quad . . \quad \ldots \quad$.. Charles J. Adams. I35I-A Shepherd's Daughter .. W. $K$. Blacklock. I352-The Llugwy, near Bettws

Thomas Somerscales, jun. i353-A Sunny Day .. .. .. ... Charles E. Flower. I354-Florence, from the back of the

Via dei Bardi .. .. . . A. H. Hallam Murray. I355-PARK House, Smarden .. .. C. W. Fothergill

\section{ENAMELS. \\ (Nos. 1356-1361.) \\ (On a Screen.)}

I356-The Right Rev. The LoRD

BISHOP OF LONDON-painting

in enamel .. .. Hubert von Herkomer, R.A.

I357-Cloisonné ENAMEL ON COPPER

Robert A. Dawson.

I358-Enamel on copper .. . . . . Ernestine Mills.

i359-Miss Julia Buckley .. .. Alexander Fisher.

I360-The Mermaid - translucent

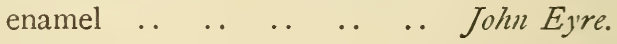

I36I-Beauty's Altar - painting in

enamel .. $\quad . . \quad$.. Hubert von Herkomer, R.A. 
I900.] WATER COLOUR ROOM.

\section{I N I A T U R ES.}

\section{(Nos. 1362-1526.)}

\section{(On a Screen.)}

I $362-\mathrm{Mr}$. W.

I363-The Countess of Charle-

VILle $\quad . . \quad$.. $\quad . . \quad$.. The Earl of Tankerville.

I364-The Countess of TANkerville

The Earl of Tankerville.

I365-Lord Ossulston .. The Earl of Tankerville.

I366-Master Ronnie Bodley The Earl of Tankerville. I 367 -Mrs. Walter Richardson .. Florence White. I368-BABY, son of Coster Edwards, Esq.

I369-Portrait of a Child .. .. Florence White. i370-Reverie .. I 37 I-JEanne, daughter of Theodore Roussel, Esq. .. $\quad$.. $\quad . . \quad$.. Alfred Praga. I372-Sunshine or Rain?.. .. .. Nellie Sanson. i373-Portrait of a Gentleman Florence McClatchie.

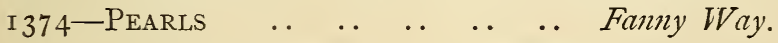

I375-MURIEL, daughter of P. Robertson-Ross, Esq.

I376-ETHEL, daughter of the late

J. Gurney, Esq. .. .. . Evelyn R. Keller. I377-Ida, eldest daughter of F. DrayI378-Aubrey, elder son of S. Fane,

Evelyn R. Keller.

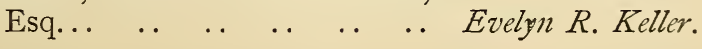


I379-MARION, younger daughter of $\mathrm{R}$.

Engledue, Esq. .. $\quad . . \quad$.. Evelyn R. Keller.

I380-Hilda Marion, daughter of W.

Wolfe Fletcher, Esq. . . . Annie G. Fletcher.

i $38 \mathrm{r}$-Mrs. Mullens .. $\quad . . \quad \ldots \quad \ldots$ Annie G. Fletcher. I 382 -ARNold WOLFE, son of W. Wolfe

Fletcher, Esq... . . . . . . Annie G. Fletcher.

i383-Miss Dorothy Freeman

Winifred H. Thomson.

i 384-Monsieur de Blowitz .. Winifred H. Thomson.

i 385-Mrs. Stanfield .. .. IVinifred H. Thomson.

i 386-Miss Miriam Clements, in 'My

Friend the Prince' .. ... Hannah E. Smith.

I387-Geoffry, son of Rev. John

Davenport .. $\quad . . \quad \ldots \quad$.. Eunice Pattison.

I388-"AlACK AND WELL-A-DAY,

Phillida flouts mé".. .. Nelly E. Cook.

I 389 -Phyllista ..

I390-F. I. Simson, EsQ. .. .. . . - Simson.

I39I-Oliver Cromwell-after Sir

Peter Lely .. $\quad . . \quad \ldots \quad$ Harold C. IV. Soper.

I392-Doris ..

I393-Portrait of a Lady .. M. Dibdin Davison.

I394-Portrait of a Lady .. M. Dibdin Davison.

i395-The late Mrs. Selfe .. M. Dibdin Davison.

I396-Evelyn and Marian, daughters

of D. Croal Thomson, Esq. .. Rosalie M. Emslie.

I397-Mrs. Wilson ..

i398-Lady Isabella Howard.. .. Rosalie M. Emslie. 
r 399-Miss N. K. . . . . . . . Rosalie M. Emslie. I 400-Esmé Helen, daughter of Major

L. Drummond .. .. .. Rosalie M. Emslie. i $40 \mathrm{I}$-Mrs. Longman .. $\quad . . \quad \ldots \quad \ldots$ Rosalie M. Emslie. i 402-Ernest Hoskins, EsQ. .. .. Rosalie M. Emslie. r403-Mrs. Brown Potter .. .. Fanny Way. I404-The Late Major - General

$\begin{array}{llll}\text { WAUCHOPE ... } & \text {. } & \text { Gwen } \\ \text { DITH, daughter } & \text { of Lionel }\end{array}$ Phillips .. $. . \quad . .$.
VA, daughter of Mrs. Massey .. children of S. Neumann, Esq. Gertrude Massey. I 408-JEAN, daughter of Roger Cunliffe,

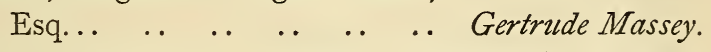
i409-Miss Katherine Cameron Charlotte G. McLaren. I4IO-Miss Burnet .. .. .. Charlotte G. McLaren. I4I I-Mrs. Burnet .. .. .. Charlotte G. McLaren. i4l 2-Miss Julia Neilson .. Mand E. Pilkington. 1413-Anna .. I4I4-The Dowager Lady Edmon-

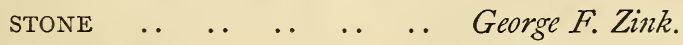

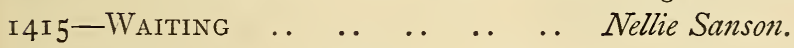
i 4i 6-Miss Laura Patricia Cowan Amie R. Merrylees. i4i7-Mrs. Middleton Rogers .. Mabel L. Hankey. I4I8-PeTER, son of Captain and Lady

Jane Seymour Combe .. .. Mabel L. Hankey. 
I4I9-ANNiE, daughter of Mrs. Marsden-Smedley .. $\quad . . \quad$.. . . Mabel L. Hanker. i 420-The Hon. Lettice Digby .. Mabel L. Hankey. i 42 I-Mrs. Thomas Fieldex .. M. Josephine Gibson.

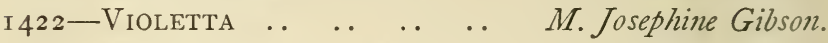
i423-Mrs. P. Jeffrey Mackie M. Josephine Gibson. i 424-Portrait of a Girl .. .. Edith $D$. Weir. I 425-ENA, daughter of James Blankensee, Esq.

Hannah Myers. I 426-Stanley, son of Sydney Krauss, Esq.

I 427-MARJORY, daughter of Sydney Krauss, Esq. I 428 -DoROTHEA . . I429-Molly and the Mouse.. .. Hannah Myers. I 430-PORTRAIT OF A LADY

I43I-The Rev. G. P. B. Viner I 432 - РATTY ..

I 433-Mrs. Rivington

I 434-MON AMI ..

I435-PORTRAIT OF A LADY

I 436 - Dr. Clement Daniel

I 437 - Mrs. Hornby Lewis

I 438 -MARY ..

I 439 - C. J. Plucknett, EsQ.

I 440-Miss Lucy IVood . .

i44I-Mrs. Phillip Dyson
Hannah Myers. Ada M. Howell. Frederick Cullen. .. Edith H. Ferneley. .. Maud B. Worsfold. .. Helen C. Beves.

.. Evelyn Mason.

. Louise Conder.

. Baldwin Warn.

. Nora Chambers. Nellie M. H. Edmunds. J. F. Acret. Alice L. Cundy. Alyn IVilliams. $Y$ seult $K$. Duvergé. 
i442-Portrait of a Lady .. .. A. Jane Harrison. I443-Portrait of an Old Lady .. Arthur Maclear. I444-Horace Mayhew, Esq. .. $R$. Cordelia Whiteside. I 445-Elaine, the lily maid of Astolat Hubert Turrell. i 446-George Edward Cokayne, Esq. Jane $K$. Robertson. I 447 -MADGE

I 448-Ruth, daughter of A. Romer

Macklin, Esq... $\quad$.. $\quad . . \quad$.. Katherine Stewart. I449-D. Shearme, Esq. .. .. .. Beatrice Howard. I 450-VERA .. i45I-Mrs. Arthur Morse Reid .. Evelyn B. Shaw, i 452-Jimmie, son of J. M. Pyke-Nott, $\begin{array}{rrrrrr}\text { Esq.... } & \ldots & \ldots & \ldots & \ldots & \ldots \\ \text { I 453-General } & \text { Sir } & \text { George } & \text { White, }\end{array}$

Evelyn B. Shaw. V.C., G.C.B. .. . . $\quad$.. $\quad$.. Harry C. Lintott. 1454-Mrs. Ricardo Palmer .. Emmeline A. Palmer.

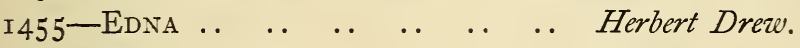
r 456-Phyllis Sachs .. I457-Portrait of a Lady .. .. J. F. Acret. i 458-Ranulph $\quad . \quad \ldots \quad$.. $\quad . . \quad$ Winifrede A. Meihé.

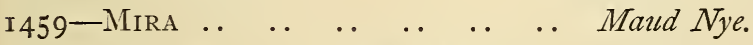
r460-Mrs. William Rutherford Gertrude T. Cowper. i46I-Miss Gertrude Shewell Adelaide C. Newman. I 462-Catherine, daughter of James

Buchanan, Esq. .. .. $\quad$ Edith M. Charlton. I463-Master Leslie S. Morgan .. Evelyn C. Ellis. I $464-$ MOLLY Eleanor S. Sterry. 
i465-Miss Madeline Forsbrey .. Emily Brown. I 466-ELsie, daughter of George Silley,

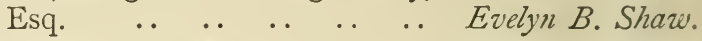
I467-Mrs. Buxton Morrish .. .. Eleanor S. Sterry. I 468 -ILEENE I 469-Miss M. i 470 -Mrs. Everard Milman ... .
r 47 I - Lady Blanche Somerset, eldest daughter of the Duke of Beaufort ..

.. Edith M. Charlton.

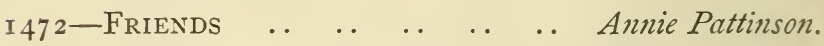
I473-Study of an Arab's Head .. Mabel Garman. I474-Dorothy, daughter of the Rev. Arthur Carter.. .. .. $K$ i 475-Miss Kimball .. $\quad . . \quad \ldots \quad \ldots \quad$ Grace $R$. Lewis. I476-A Study in White .. .. .. Herbert Turrell. I 477 -The ButTerfly

. . Rosabella Drummond. r 478 -Portrait of a Child I 479-Portrait of a Child r 480 - Why so Pensive, Gentle

\section{MaIden?}

I 48 I -FRIDA ..

I 482 -PRISCILLE

1483 -Poppies

I 484 -Mrs. Porter

I 485 -EDith, daughter of E. Mead,

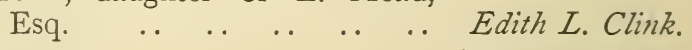

i486-Marjory $\quad . \quad \ldots \quad \ldots \quad \ldots \quad \ldots \quad \ldots$ Ethel Buckingham. 
I487-A Dear Old Friend .. .. Mildred Robinson. I488-Christabelle .. $\quad . \quad$. $\quad \ldots$ Mary L. Mileham. i489-Miss Constance Collier Francis A. Haviland. I490-Portrait of a Lady .. .. Ada Whiting. I $49 \mathrm{I}-\mathrm{N}$. G. : a portrait .. .. Gerald E. Harrison. i492-Portrait of a Lady .. .. Edith L. Clink. I 493-Madame Sara Bernhardt, in

'La Dame aux Camélias' .. Winifred Marshail. I494-Maisie $\quad \ldots \quad \ldots \quad \ldots \quad$.. Madeline M. McDonald. I495-Mrs. F. E Wear .. .. $\quad . . \quad$ Maud Wear. I496-A Lady of a Bygone Day .. Florence Lendrum. I497-Wilfred .. .. $\quad . . \quad \ldots \quad$ Minnie J. Hardman.

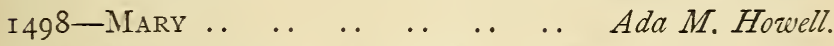
I499-Miss Dorothy Wickham Henrietta $M$. Tarver. I500-Chrysanthemums $\quad . \quad \ldots \quad$.. Lillie Stein. $\mathrm{I}_{5} \mathrm{OI}$-E. W. TAIT, EsQ. .. $\ldots$.. $\quad$. Frederick Cullen. I502-Frank RichuoNd Kimbrough,

EsQ. $\quad$.. I503-F. L. B. .. $\quad \ldots \quad$.. $\quad \ldots \quad$.. $\quad$ L. Hilda Bell. I 504-Mrs. Massey .. i505-Portrait of a Gentleman Margaret $A$. Heath. I 506-Martin Kemp-Welch, EsQ. ...Edith Kemp-Welch. I $507-Z_{\mathrm{AZA}}$

I508-The Garland I 509-Miss Cox I5IO-MISS HARTWELL Isabel Pyke-Nott. Cecil J. Hobson. Adah Knight. Grace R. Lewis. 
I 5 II-Rev. C. B. LeWIS

I 5 I 2 -KathleEN .

i5I3-Mrs. Drinan .

I5I4-Sketch of an Italian Girl.. Grace $R$. Lewis.

I5I5-Miss Mildred Bennett.. Henrietta M. Tarver.

i5i6-Miss Josephine Tarver.. Henrietta $M$. Tarier.

I5I7-Our Rector ..

I5I8-" Dark eye'd Carlotta, FANCY

RAPT AFAR, WHERE ALL FAIR

FORMS AND ALL CLEAR COLOURS

ARE" $\quad$.

15I9-Miss Enily G. Dockerill .. Margaret Dockerill.

1520-Portrait of a Boy.. .. .. Baldwin Warn.

I52I-Mrs. Harrington .. .. .. Edward Deanes.

I522-VERE .. $\quad . . \quad \ldots \quad \ldots \quad \ldots \quad$ Henrietta M. Tarver.

I523-Eveline, daughter of John

Hilton, Esq. .. .. .. Beatrice A. Higham.

I524-Hon. Mrs. Duff Tollemache - Simson.

I525-A Reverie.. ..

I526-ISABEL, daughter of Lieut.-Col.

J. E. Baines .. $\quad . . \quad$.. $\quad$ Maud I. Wilkinson. 
I900.]

\section{BLACK AND WHITE ROOM.}

ETCHINGS, DRAWINGS, AND ENGRAVINGS.

(Nos. 1527-1679.)

I527-The Coal-Heavers .. .. .. Estelle Nathan. I528-FAITH - after Lord Leighton, P.R.A. .. $\quad$. $\quad$.. $\quad$.. $\quad$..

John D. Miller. I529-The Pride of North Devon Fred Burridge. I530-Design For WAR FUnd ProGRAMME ...

I53 I-ST. William's College, York

Patten Wilson. I 532-Vanished London : Clare Market I533-A Clyde Harbour. I534-The LAMENT OF ICARUS-after H. J. Draper.. .. .. .. Arthur Comfort. I 535-SWALEDALE. .

.. Charles J. Watson. i 536-Mill above the Mersey .. A. Hugh Fisher. I537-The Edict of William the Testy-after G. H. Boughton, R.A. $\quad$.. $\quad$.. $\quad$.. $\quad$.. $\quad$.. Willie Heydemann. I538-Hermia AND Helena-after Sir E. J. Poynter, P.R.A.

.. Willie Heydemann. I539-Book-Plate George W. Eve. 
I540-The Hundred River

Frank Newbolt.

I $54 \mathrm{I}$-The Thatchers

A. Hugh Fisher.

I542-Dock Building: Liverpool .. T. Hamilton Hay.

i 543-The Maids of Elfin-Mere ..

I 544-On the Thames above Staines

I 545 -Putney

I546-ON the Banks of the Colne

I 547 -Dover Cliffs

Amelia Banerlé.

John Fullwood.

Catherine Smith.

I 548- "Against THE WIND AND OPEN

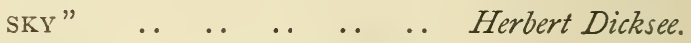

I549-The Path By The Mill-after

Yeend King ..

I550-ACHILles - after Rembrandt .. Mortimer Menpes.

I55I-The Favourites of the Hunt

Robert W. Macbeth, A.

I552-Church of St. Mary, Rye .. W. H. Milnes.

I553-ON The Downs near Ports-

MOUTH ..

i554-Oude Munt Toren, Amsterdam Constance M. Pott. I 555-SEA-WRACK

.. R. Stewart.

I556-The Depths of the Sea

I 557 -Tyrolese Cottages..

. Amelia Banerlé.

I558-AN OLD BARN ..

.. Edward M. Synge.

I559-HAY-Barn, Cortina

.. $\quad W . H$. Milnes.

I560-A Norfolk Bridge.

.. Edward M. Synge.

i56i-Near Clifton ... .. ..

W. H. Milnes.

i562-Blowing the Fire .. .. .. Gertrude E. Hayes. i 563-The Trial Proof $\ldots$.. $\quad$. Constance $M$. Pott. 
I564-The Watcher on the Hill.. Herbert Dicksee. I 565-Jerusalem, from Olivet .. .. Tristram Ellis. I566-The Weaver .. I567-"WhITE AS THE SNOW WERE HIS LOCKS, AND HIS CHEEKS AS BROWN AS THE OAK LEAVES." -Longfellow .. $\quad . . \quad$.. $\quad$.. Ethel M. Morgan. I568-The Honeymoon - after W. Dendy Sadler .. $\quad . . \quad$.. $\quad$.. James Dobie. I569-Old Building on the Darro, Granada-after D. Roberts, R.A. $\quad . . \quad \ldots \quad$.. $\quad . . \quad$.. Luke Taylor. I570-In the Furrowed Land ...Minna Bolingbroke. I 57 I-Butter-Market, Dordrecht .. Mary A. Sloane. I 572 -Washing-Sheds, Avranches .. Gertrude E. Hayes. I 573-A Book-Plate .. $\quad . . \quad \ldots \quad \ldots$ Frederick C. Tilney.

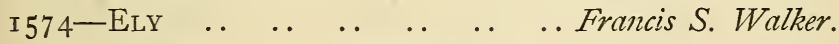
I575-Study of a Cat's Head .. George H. Short. I576-The Lonely Life-after Hugh G. Riviere .. .. .. Charles O. Murray. I577-The late Rev. Dr. Martineau Clara Martineau. I578-Anxious Hearts .. .. .. Herbert Dicksee. I579-Illustration FROM 'King LeAR,' act iv. scene 7... .. Cyrus Cuneo. I580-Portrait of a Noblemanafter Franz Hals .. .. .. Arthur J. Turrell. i58I-Madam Brunetti .. .. Reginald E.J. Bush. i582-The Penitent .. I583-A Воok-Plate .. $\ldots \quad \ldots \quad \ldots \quad$ C. $W$. Sherborn. 
I 584-Moonlight $\quad . . \quad \ldots \quad \ldots \quad \ldots \quad$ Ida Lees.

i 585-Youth and Death .. .. .. Alfred G. Jones. I586-YORICK, THE PARSON, AND HIS

Old Horse .. .. .. Harry L. Richardson. I587-Wounded Men at Wynberg, South Africa : a shady corner Arthur Garratt. I588-Design For HeAding of Mr.

Punch's i i 8th Volume .. Linley Sambourne. i 589-Death Waits at the Door Clande A. Shepperson. i590-In ArCadia ..

159I-The Dowager Countess of

CRAWFORD AND BalCarRES

Sir W. B. Richmond, R.A.

I592-The Castle, Holy Island,

Northumberland .. .. Thomas W. Hammond.

I593- "Bobs" Eyes : a sketch on

Orange Free State Border .. Alfred Pearse.

I 594-Illustration FROM 'King

Lear,' act i. scene I .. .. Cyrus Cuneo.

I595-King Cophetua AND The

BegGar MAID .. .. Eleanor $F$. Brickdale.

i596-Miss Meggie Barclay .. .. Harold Speed.

I597-Lorenzo and Isabella .. .. Frank C. Cowper.

"' 'How ill she is,' said he. 'I may not speak;

And yet I will, and tell my love all plain

If looks speak love-laws.'"

Keats' 'Isabella, or the Pot of Basil.'

I598-Colonel Sir Edward R. C.

Bradford, G.C.B. Drawing

for the Grillions Club Series .. H. T. Wells, R.A. 


\section{0.] BLACK AND WHITE ROOM.}

i599-Beside Still Waters .. .. Lester Sutcliffe. i600-Flaniboro' Head .. .. Thomas W. Hammond. I60I-VETERANS READiNg the WAR

News in Chelsea Hospital Arthur Garratt. i6o2-Master Christopher Barclay Harold Speed. i603-Death and the Soldier .. Sam Webley. i604-The Fight _. .. .. Claude A. Shepperson. i605-A Rainy Day .. $\quad . . \quad \ldots \quad \ldots$ Alfred W. Cooper. i6o6-The Lady Wantage Sir W. B. Richmond, R.A. i607-Study .. i 608-The Love-Letter .. .. .. Harold Copping. i609-John Alexander, EsQ. .. .. Montagu Crick. i6io-Illustration to Poem "The HAPPY ISLES" $\quad . . \quad \ldots \quad \ldots$ J. Walter West. i6i i-The Silext Highway .. .. Leonard Alford. i6i 2-Four Drawings of Tigers .. Alice $K$. Goyder. i6i3-A Friar of Orders Grey Thomas $W$. Holgate. I6 I 4-Lilies-after Mrs. M. L. Waller John C. Webb. i6i5-Mrs. Walter Medlicott

Sir W. B. Richmond, R.A.

I6i6-OfF to THE Fishing-Ground : Holy Island, Northumberland

Thomas $\mathrm{W}$. Hammond.

i6r7-Design for a Book-Plate Harold E. H. Nelson. I6r8-EveNiNG i6i9-An Interrupted Idvll... .. Frank Craig. i620-6Th Dragoons Leaving Albert

Docks for SOUth Africa.. Fred. Whiting. 
i62 I-A Cheshire Faril .. .. .. Hugh Paton. I622-Two Crotchets in a BAR William J. Urquhart. I 623 - "I 844 " I624-REPOSE I625-CROSSING THE MOOR I6 6 - My SisTer.. i627-The Stranger .. I628-MARPESSA ... .. I629-A LAD IN LOVE I630-Sweet Thoughts i63I-Rough Sea: H.M.S. 'Powerful' T. Robinson. I632-IVith Troops for Table Bay: transport leaving the Royal Albert Docks .. $\quad . . \quad$.. $\quad$.. Charles J. De Lacy. I633- "LOVE IN HER EYES SITS PLAY- ING"
Charles E. Marshall. I634-Moonlight $\quad . \quad \cdots \quad .$.
I6 35 -Udea ANd THE MAN-EATERI635-Udea And the Man-Eater-
Lang's 'Grey Fairy Book'
I636-Gareth And Lynet J. Ford.

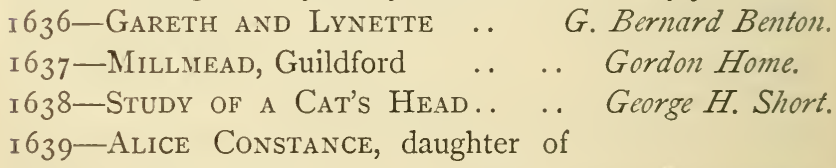
Archibald Baldwin.

Sir Thomas Richardson, M.P. Seymour Lucas, R.A. I640-"MURTHER MOST FOUL, AS IN THE BEST IT IS."-Shakespeare Nell Tenison. I64I-H. G. Gwyther, EsQ. . . Seymour Lucas, R.A. i642-Barabbas at The Cross Sir W. B. Richmond, R.A. 
I900.] BLACK AND WHITE ROOM.

1643-The Great Reserve .. G. Bernard Benton. i6 64-Clarissa r645-The Attenipt to Save the Guns at Colenso .. .. Christopher Clark. i646-Illustration to Poem, "Love Lies Bleeding" $\quad . . \quad$.. $\quad . . \quad J$. Walter West. i647-Illustration to "Colonel Botcherby, M.F.H." .. Ralph J. Richardson. i648-The Prioress's Tale .. .. William D. Eden. 1649-The Plough .. .. . . . . Emest T. Gurney. r650-The Convent's Chronicler .. Philip Connard. i65 I-Ophelia 1652-Miss Annie WARD .. .. .. Lilian F. Wright. 1653-A Study .. 1654-The Cat-Witch _. .. Gertrude M. Bradley. 1655-The Monarch of the Glenafter Sir Edwin Landseer, R.A.

Herbert Sedcole. i656-An Illustration to a Story G. Henry Evison. 1657-Bellerophon SLAYing the Chimaera 1658-An EMPire of Dreams .. .. Elsie Gregory. i659-APPLES .. I660-REVERSE OF DESIGN FOR WAR Fund Programme .. i66r-Portrait of a Lady .. .. Ethel Sazwyer. i662-Study of a Cat's Head.. .. George H. Short. i663-Lancelot and Elaine .. G. Bernard Benton. I664-MaRIa LEAVING THE BanQUeT -Lang's 'Grey Fairy Book'.. Henry J. Ford. 
I665-" "WHO RIDES BY WITH THE

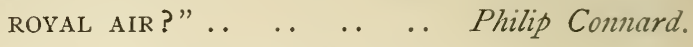
i666-The Right Rev. T. E. IVilkinson, D.D., Bishop of Northern \& Central Europe .. .. .. Frank Willis. I 667 -StoRy Illustration-after Seymour Lucas, R.A. .. $\quad$.. $\quad$.. Arthur Comfort. I668-The Rose MAIDEN-after S. Melton Fisher .. $\quad . . \quad$.. John C. Webb. I669-The QUESTION-after Marcus Stone, R.A. $\quad$.. $\quad$.. $\quad$.. $\quad$.. $\quad$ Norman Hirst.

I670-A WeLCoMe Footstep-after Marcus Stone, R.A. . . . E. Gilbert Hester. I67I-MOORLAND QUIETUdE - after Peter Graham, R.A. .. .. Joseph B. Pratt. 1672-WEDDED-after Lord Leighton, P.R.A.

I 673-GABRIELLE - after Schmalz ... . . . . .
DVERSITY-after J. Sant, R.A. H
ANCY FreE-after A. Stuart

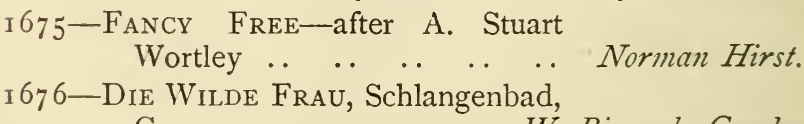

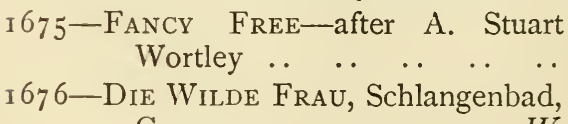
Germany Herbert I 674-Adversity-after J. Sant, R.A. Henry T. Greenhead. 1677-London, from Hampstead .. William Monk. i678-The Nurse-Girl .. .. .. Gordon Bromune. r679-Illustration to "The HunDredth Princess" .. Alice B. Woodrciard. 


\section{ARCHITECTURAL ROOM.}

\section{A RCHITECTURAL D RAWINGS.}

\section{(Nos. 1680-1912.)}

I680-Holwell, Herts : exterior Ernest George and Yeates. I681-EDGEWORTH MANOR, Cirencester: hall screen Ernest George and Yeates. I682-Proposed HoUSE IN THE NORTH

of Scotland .. .. .. Walter R. Davidson, i683-A Country Cottage, near Stratford-on-Avon .. .. . . Joseph C. Perkin. i684-ITalian Hospital, Queen's

Square, London .. $\quad . . \quad$.. Thomas W. Cutler. I685-Proposed House, Thames Ditton i686-Proposed New Church, Newcastle-upon-Tyne .. .. .. George W. Ward. i687-Cottage, Hampshire .. .. Thomas Davison. i688-Martin's Bank, Bromley .. Ernest Newton. i689-The Medical Schools, Cam-

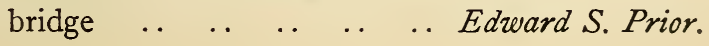


I690-New BuIldiNgs For The Uni-

versity of Cambridge Thomas G. Jackson, R.A. I69I-RECONSTRUCtion OF Wester

Kames Tower, Isle of Bute .. Robert W. Schultz. i692-Music-Room at I, Cadogan

Place .. I693-24, Duke Street, Piccadilly, W.

George A. Lansdown. i694-Country House, Almondsbury,

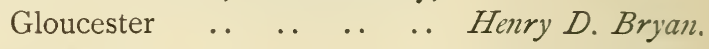
i695-Design For Art Galleries,

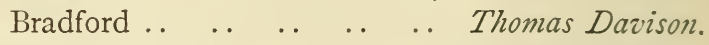
i696-A Sunk Garden .. .. .. Henry Tanner, jun. I697- 'The Old Horse and Jockey,'

Hazel Grove .. $\quad . . \quad$.. $\quad . . \quad$ Mee and Jennison. i698-Stelling Hall, Northumberland Armstrong and Wright. I699-A Scheme for the Supply of WATER FOR LONDON .. .. Robert P. Whellock. I 700-The Retreat, Lakenham,

Suffolk: entrance, front.. Andrew N. Prentice. i 7oi-Front for Restaurant.. .. M. Starmer Hack. I 702-Pair of CotTages, Shellingford,

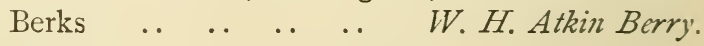
I 703-Group of Four CotTAges, Shellingford, Berks.. .. IV. H. Atkin Berry. I 704-InHolues, Hartley Wintney,

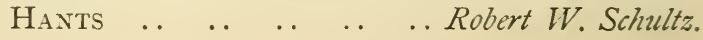


I705-Boys' School AND Master's

Residence at Exeter ..Bryan and Roberts.

i 706-Firemen's Cottages, Todmorden Jesse Horsfall.

i707-Sketch Design for Stained

Glass : "Christus Consolatus"

William Glasby.

i708-Design For House in New

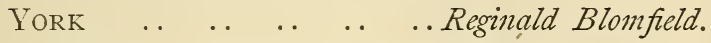

I709-Design For Village Church

on a Hill Slope.. .. ...R. Samuel Oldacre.

I 7 Io-New Church, Sledmere Park,

Yorkshire : interior view .. Temple Moore.

i7II-Design For Stained Glass

Window: "The Nativity" .. William Aikman.

i7 I 2-Design for New Chancel, St.

Paul's Church, Bermondsey ... Herbert C. Ingram.

I 7 I 3-Organ-SCREEN ANd ChoIr-SEATS,

church of St. Merteriana,

Tintagel ..

i7i4-Design for a Stained Glass

Window ..

I7I5-House at Leicester .. .. James Ransome.

i 7 i 6-Proposed Offices, West Hartle-

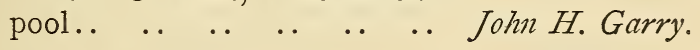

I7 7-House at Wembley Hill

Gibson, Clarke, and Warwick.

I7 8-Design for Stained Glass William J. Griffiths.

i7I9-Entrance Gates and Lodge

to Mansion, Suffolk .. Andrew N. Prentice.

I720-LeA PARk, Surrey .. .. Paxton H. Watson. 
I 72 I-House at Warlingham, Surrey

Harrison and Ward.

I722-King's COllege School,

Vimbledon : view of front

Banister Fletcher and Sons.

I723-"The OLD HOUSE AT HOME,"

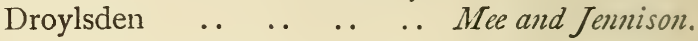

I724-DESIGN FOR THE HALL OF A Country House .. .. .. Gervase Bailey.

1725-House, Weymouth Park, Waltonon-Thames .. .. Niven and Wigglesworth.

I726-House at Willenhall Park,

Barnet ..

I 727-St. StePhen's National

ScHOoLs : north front, showing

new extension and additional

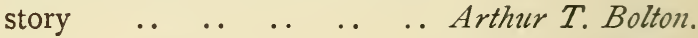

I728-House at Hendon .. .. .. George Hormblower.

i 729-Design for Proposed Church

OF ST. EDward, Barnsley,

Yorkshire $\quad . . \quad$.. $\quad . . \quad$.. Harold C. Trinnell.

I730-COMPetitive Design FOR

Church at Barnsley.. Charles A. Nicholson.

I73I-DESIGN FOR FAÇADE OF A

Military Museum .. .. John E. Spain.

I732-Plumstead Municipal Build-

ings AND PUblic LibraRy :

second premiated design Hall, Cooper, and Davis.

i 733-The Grange, Totteridge.. Charles A. Nicholson. 
I734-A Herefordshire House AND

Garden .. $\quad$.. $\quad$.. $\quad$.. Thomas H. Mazeson.

I735-Bungalow Hall, Altrincham .. Henry Goldsmith.

I736-Terrace AND Pavilion fOR A

Staffordshire Garden Thomas H. Mazeson.

r737-Design for Hill-Side Garden,

Windermere .. .. .. Thomas H. Mazeson.

I738-Design fOR GRILle and CAR-

TOUCHE IN WROUGHT IRON

Frederick C. Tilney.

I739-Design FOR StaINed Glass

Window: "St. George" .. George Parlby.

i740-Proposed New Club-House

FOR THE WINGHAM GOLF

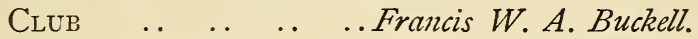

I74I-Study for a Pulpit .. .. Cyril E. Power.

I 742-Town HaLl, Clitheroe Briggs and Wolstenholme.

I743-Design for Refitting Mission

Church at Walworth Charles A. Nicholson.

i 744-House at Pinner .. .. Edward B. Wetenhall.

I745-EdGe Hill, Limpsfield .. .. Arthur Keen.

I746-St. John the Baptist: design

for stained glass .. $\quad . . \quad$.. George Parlby.

I747-53, Maddox Street, W... Harrison and Ward. I748-PARR'S BANK, Limited: new

building, Castle Street, Liver-

pool R. N. Shaw, R.A., Willink, and Thicknesse.

I749-Chancel Fittings: Chester Charles A. Nicholson. 
I750-Free Library and TeChNical Schools, Leamington: premiated design.. $\quad . . \quad$.. .. John E. Newberry.

i75 I-Design For Stained Glass Window: "Moses at the

Burning Bush" .. .. .. William Aikman.

I 752 - Proposed Clock-Tower, Yorkshire $\quad$.

I753-Crown oN Tower of Church

at Belmont Bridge, Glasgow John J. Stevenson. i754-Design for a Chapter-House Percy E. Neüton. I755-The LibraRy, Westbrook Hall

Charles A. Nicholson.

i 756-House at Cobham: the hall M. H. Baillie Scott. i757-Drawing-Room Mantelpiece George M. Ellwood. i 758-House at Richmond .. .. Walter $R$. Jaggard. I 759-Windows IN INGLENOOK AT Sarita, Nethersole Gardens, Finchley Road .. .. .. Arthur A. Orr. I760-Designs FOR URBAN District Council's Offices in a Small Country Town .. $\quad . . \quad \therefore \quad$ Harold Falkner. i76I-Design for Sideboard ... ... Edward O. Clark. i 762 -Designs for Furniture.. .. Edward O. Clark. I 763 -The Roxeth Schools, Harrow-

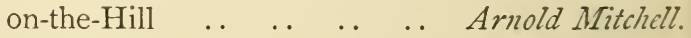

I764-Science AND ART Schools,

Leamington .. .. C. E. Mallows and Grocock. 
I765-DESIGN FOR A CHURCH AT

Exeter .. $\quad . . \quad \ldots \quad \ldots \quad \ldots$ Hubert C. Corlette.

I 766 -BuILDING FOR LLOYD'S REGisteR

of ShipPing: corner of building Thomas E. Collcutt.

I 767 -Business Premises, Kingston-on-

Thames .. .. .. J. T. Wimperis and Arber.

I768-New PUblic Library, Forest

Hill : exterior.. .. .. Alexander R. Hennell.

I769-DESIGN FOR CHURCH AND

ViCarage, Barnsley, Yorkshire Hubert C. Corlette.

I770-The Steep-House, Keswick .. W. H. Ward.

I 77 I-BILLIARD-Room, 8, Wedderburn

Road, N.W. .. .. .. .. A. H. Belcher.

I 772 -King's College School, Wimble-

don Common .. . . Banister Fletcher and Sons.

I773-House AT DEAN Row, Cheshire Mee and Jennison.

I774-House, Edgerton, Huddersfield Edgar Wood.

I775-Studies fOR WALL-Papers .. Rupert C. Austin.

I776-Parochial Institute, Outwood

Butler, Wilson, and Oglesby.

I777-DESIGN FOR BLOCK-PRINTED

Chintz: "Spring" ..H. Gertrude Hildesheim.

I778-New Church, Sledmere Park,

Yorkshire $\quad \ldots \quad \ldots \quad \ldots \quad$.. Temple Moore.

I779-DESIGN FOR OVERMANTEL AND

its Decoration $\ldots$..

I780-BuildiNg FOR Lloyd's Register

OF SHipping, Fenchurch Street

Thomas E. Collcutt. 
I78 I-BUILding For LLOYd's Register OF SHIPPING .

Thomas E. Collcutt.

i782-Printing Premises, Cornwall

Street, Birmingham .. Bateman and Bateman.

i 783-Sand Hill Close, Hitchin, Herts

Thomas G. Lucas.

I 784 -Design for Dining-Room Deco-

ration ..

I 785 -New Shop-Front, 94, Park Street,

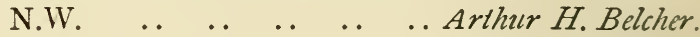

i 786 -Pulpit for New Parish Church

of St. Stephens', Bexhill .. Henry Ward.

I 78 -Manchester Warehouse, Can-

non Street, Birmingham.. Bateman and Bateman.

I788-OCEAN INSURANCE CORPORA-

TION Buildings .. .. .. H.l Huntly-Gordon.

i789-All Saints' Convent, Colney

Chapel, St. Albans: entrance

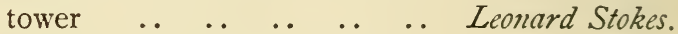

I790-Frithwood House, Northwood

Mervy" E. Macartney.

I79I-A House by the Sea .. .. Arthur Stratton.

I792-Design For Stained Glass

Window .. $\quad . . \quad \ldots \quad . . \quad \ldots$ Arthur C. Lavers.

I793-Stained Glass Window, Chefoo,

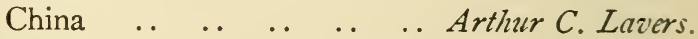

I794-Bristol Tramways, Brislington

Depôt .. 
i795-House at Headley Hill,

Hants

i 796-ICkleton Grange .. .. Charles A. Nicholson. I797-Welder's, Chalfont St. Peter's,

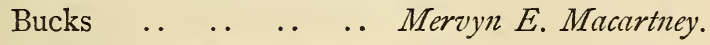

I798-Competitive Design FOR A

Public Building .. .. Mervyn E. Macartney.

I799-First HALF OF a Frieze OF

Atric Months .. $\quad . . \quad$.. John S. Babb.

I800-House at Cley, Norfolk

E. G. Dawber and Whitwell.

i801-Design for a Country House George J.J. Lacy. I802-BRADFIELD COLLEGE: new

boarders' house .. .. Mervyn E. Macartney.

I803-Design For Public School

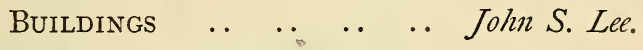

I 804-House AT Winderitere: en-

trance front $\quad . . \quad \ldots \quad . . \quad$..M. H. Ballie Scott.

i 805 - Two Houses at Godalming,

$\begin{array}{llllllll}\text { Surrey } & . & \text {. } & \text {.. } & \text {. } & \text {.. } & W . & \text { H. Seth-Smith. }\end{array}$

i806-Tourelle, Halifax .. Butler, Wilson, and Oglesby.

i807-Competitive Design for Muni-

CIPAl Buildings, Plumstead

Ardron, Dawson, and Howell.

I 808-Rood-Loft and Screen, Bark-

ston Church, Lincolnshire .. Harold Bailey.

I8o9-Homeside, Wimbledon Common Edward J. Maj'. I8ro-Free Library, Wolverhampton Henry T. Hare. 
i 8i i-Château Mauricien, Wimereux John Belcher, A. i 8I 2-New Church OF St. Mark, Plumstead, with institute, parish hall and parsonage.. ...Charles H. M. Mileham. i8r3-Design for a Stained Glass

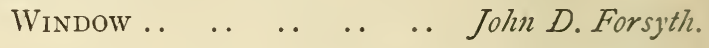
i 8 i 4-Bamborough, Sheepcote Road, Harrow-on-the Hill .. .. Lionel Barrett. i8r5-Design for a Stained Glass Window .. I8I6-Design For CARTwright MeMORIAL HALL, Lister Hall, Bradford .. .. ...H. Cheston and J. C. Perkin. i 8i 7-Interior of Moot Hall, Colchester Town Hall.. .. .. John Belcher, A. I8I8-NEW BUILDING FOR THE Eastern Telegraph ComPANY : portion of façade .. John Belcher, A. i8i9-Second Half of a Frieze of Attic Monthe .. .. $\quad .$.
i 820--Church ington, Dorset $\quad$.. .. .. William D. Caröe. I $82 \mathrm{I}$-NEW BUILDING FOR THE Eastern Telegraph ComPANY: elevation in Finsbury Pavement .. John S. Babb. 
I824-Font-Cover For Grantham

Parish Church ..

i 825-Design Submitted for the ReBUILDING OF THE WESLEYAN

Centenary Hall, Bishopsgate, E.C. $\quad$.. $\quad$.. Banister Fletcher and Sons. i826-House at Shelford .. .. George H. Shackle. i 827 - House in Sloane Street, S.W.

R. Gardner Hammond.

I 828-BRISTOL TRAMWAYS POWER-

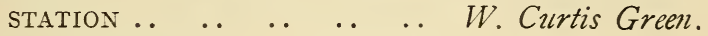

i829-St. Stephen's National ScHools: south front, showing boys' and girls' staircases, and view of head of girls' stairs

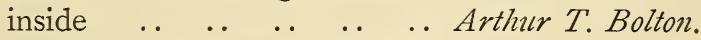
I830-Bungalow, Adelaide, S. Australia

W. H. Atkin Berry. I83I-Design For a Clock-Tower .. Herbert Raine. I832-Study for a Street Front, in glass mosaic and faience .. Beresford Pite. i833-Competitive Design For Church at Sparkbrook, Birmingham .. .. .. Mervyn E. Macartney. I834-New Tower, St. Michael's, Bournemouth .. $\quad . . \quad \ldots \quad$.. $\quad$ J. Oldrid Scott. i835-House at Letchiore Heath $W$. Campbell Jones. i8 36 -House at Tunbridge Wells $W$. Campbell Jones. 
I837-Four Houses, Harrogate.. .. Bland and Bown. I838-Binton Barn, near Farnham Paxton H. Watson. I 839-New Lych-Gate, Huish Episcopi,

Somerset.. $\quad . . \quad$.. $\quad . . \quad$..Rowland W. Paul. i840-38, 39, Cheyne Walk, S.IV. .. C. R. Ashbee. I 84I-EAST WINDOW, St. Lawrence's

Church, Morecambe .. .. Shrigley and Hunt. I842-Screen in Wrought Iron .. John J. Shaw. i843-A Modern Country House in the i8th Century Manner Walter Cave. I844-Window, Gloucester Cathedral

Christopher $W$. Whall. I 845-PiPer's Hill, Byfleet, Surrey ..

Niven and Wigglesworth.

i846-Municipal Buildings and Free Library, Plumstead

Russell, Mallows, and Grocock. I847-ADDitions TO A House IN Hertfordshire .. $\quad . . \quad$.. Roland $W$. Paul. i848-House near Hythe .. .. James A. Minty. I849-Design For Stained Glass Window: "The Adoration of

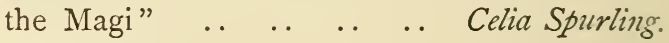

i 850-Proposed New Public Baths FOR THE BOROUGH OF ST. Pancras.. $\quad$.. $\quad$.. $\quad$.. $\quad$.. R. Stephen Ayling. i 85 I-Design For a Stained Glass Window: "The Sojourn in

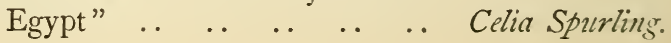


I852-Summer-House AT ENd OF

GARDEN WALK .. .. Thomas H. Mazeson.

i853-Design For a DeCorative

Panel ..

i 854-New Parish Church of St.

Stephen, Bexhill .. .. .. Henry Ward.

I855-BRANKSOME, Buxton: entrance

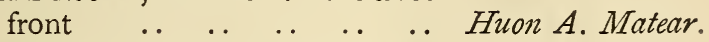

i 856-Additions to Balconile Place:

garden front .. $\quad . . \quad$.. $\quad$. Gerald C. Horsley.

i 857-Design for Stabling .. Edgar S. Underwood.

I858-Wellingborough Cottage

Hospital .. .. .. Sharman and Archer.

i859-Bath-Room, in tiles and mosaic Charles H. Temple. I860-The Music-Gallery, Balcombe

Place, Sussex .. $\quad$. $\quad . . \quad$.. Gerald C. Horsley.

i86i-Architectural Studies.. .. Jan Kotéra.

i862-Architectural Studies... .. Jan Kotéra.

I863-Glen Falcon, Isle of Man : the

dining-room $\quad . . \quad \ldots \quad \ldots \quad \ldots M$. H. Baillie Scott.

i 864 -Design for a Grammar-School H. Inigo Triggs. I 865-South Lytchett Manor, Dorset William D. Caröe. i 866-Royal College of Science,

Imperial Institute Road, South

Kensington ..

I867-DESIGN FOR A TOWN AT THE

ENTRANCE OF THE PROPOSED

Submarine Channel Tunnel Jan Kotéra. 
I868-DESIGN FOR THE DARTFORD

BOARD SchOOLS .. .. . . Arnold Mitchell.

I 869-The, White House, Helensburgh :

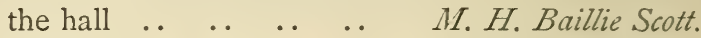

I870-House at Crowborough : the

dining-room .. $\quad . \quad$.. $\quad$ M. H. Baillie Scott.

I87I-Entrance Front : London

Road, Newark A. W. Brewill and B. E. Baily. I 872 -Proposed CeILING For CONCERT

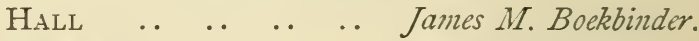

I873-A Roman Fantasy .. .. .. Jan Kotéra.

I 874 - "Ramsay Arms," Fettercairn, N.B.

T. Martin Cappon.

i875-Competitive Design for Cart-

wright Memorial Hall .. H. H. Statham.

i876-PORCh at Halifax .. Butler, Wilson, and Oglesby. I877- "Ye ANGel Hotel," Ilford,

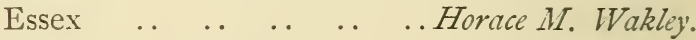

I 878-House Near Gibraltar: part

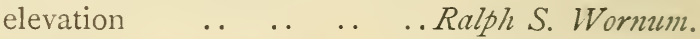
I879-Windylea, Horsforth, Yorkshire Frederick Musto. I880-A House, I899 .. . . . . . . Arthur C. Martin. i $88 \mathrm{I}$-New Government Offices :

the Circular Court.. .. .. John M. Brydon. I882-Hill CREST, overlooking Rye,

Sussex ..

I883-The Priory, Steyning .. .. Frank Foster. i 884-Rookery, Harpenden, Herts .. Percizal C. Blow. 
I 885-MeMoRIAL TO THE LATE LORD

Hillingdon ..

i886-Headland Cottage, Limpsfield Arthur Keen.

r887-Sketch Designs for Tapestries Alfred Carpenter.

I888-AN Entrance Lodge .. .. $H$. Inigo Triggs.

i889-Episcopal Palace, Bristol .. William D. Caröe.

I890-NEW BUILDING FOR THE EASTERN

Telegraph Company : view

of main cntrance .. .. . . John Belcher, A.

I89I-PART OF New INFIRMARY,

Sheffield .. $\quad . . \quad$.. . . Edreard W. Mountford.

I892-New Town HaLL, Hitchin,

Herts .. .. E. W. Mountford and G. Lucas.

I893-St. Stephen's NAtional

Schools : interior and exterior

sketches of new work .. .. Arthur T. Bolton.

I894-House AT St. AnN's-on-SEA .. Mee and Jennison. i 895-Proposed Wrought-Iron Gates $A$. Harold Smith. I896-A White House, Welwyn Granville E. S. Streatfield. i897-Penshurst Village Club ..Maxwell M. Smith. I898-Building, 59, Bath Street,

Glasgow .. $\quad . . \quad \ldots \quad$.. $\quad$ Thomas L. Watson. r899-House at Moniaive, Dumfries-

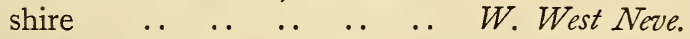
I900-GARDEN FRONT OF HOUSE IN Rosecroft Avenue, Hampstead, N.W. .. $\quad . . \quad$..Charles H. B. Quennell I90I-New Hospital and Nurses'

Home, Frome, Somerset B. Vaughan Johnson. 
I902-Ingle in Dining-Room, Danesford, Bridgnorth .. $\quad . \quad$.. Thomas E. Pryce. I 903-New Rectory, Harston, Leicestershire

I 904 - House at Brooklands, Cheshire I905-Design FOR a Fireplace

igo6-Design For Stained Glass

Window ..

I907-Stranger's Corner, Farnham,

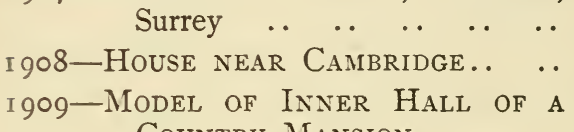

igo8-House near Cambridge.. .. Horace Field. Country Mansion .. ..

$\begin{array}{llll}\text { igio-Model of a Cottage } & \ldots & \ldots \\ \text { igi I-Model of Rushmere } & \text { Lodge, }\end{array}$ near Ipswich ... .. . . $\quad .$.

igi 2-Design for the Mosaic Deco-
Ration of Pendentive: "St. Matthew" $\quad$. $\quad . . \quad$. $\quad . . \quad$ George Murray. 


\section{CENTRAL HALL.}

\section{SCULPTURE-(Nos. 1913-1939).}

i9i3-The Devotion of Æneas-

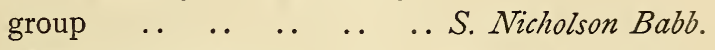
I9I 4-In Memoriam-group, marble.. Margaret M. Giles. "He shall give his angels charge over thee."

I9I5-Sir SydneyjiWaterlow, Bart. Model of statue to be erected in Waterlow Park, Highgate Frank M. Taubman. I9I6-The BROKEN Bow-statue .. Herbert Hampton. I9I7-A Roval Hunter - group, bronze ..

igi8-Thomas E. Collcutt, Esq.-

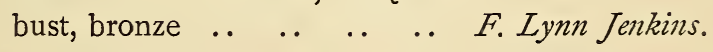
I9I9-E. Borough Johnson, EsQ.-

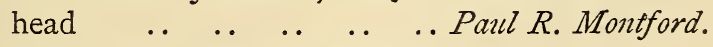

I920-Terminal to Carry a LaMp-

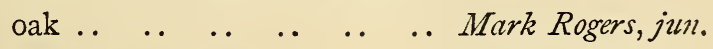
I92 I-HERMES-statuette .. $\quad . . \quad$. . John Hughes. I922-Alderman John HARRISON-

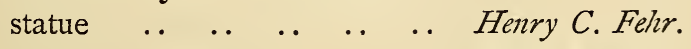
I923-"Now I'm A FAIRY" .. .. Mary Pownall. 
i924-The Pride of Old England

-group .. $\quad . . \quad \ldots \quad \ldots \quad \ldots H . R$. Hope-Pinker.

i925-Captain Pavy-bust, bronze ..D. Arthur Thomas. I926-The LORD OverTOUN-bust,

bronze ..

I927-Death-group .. $\quad . . \quad \ldots \quad \ldots$ George E. Wade.

I928-Geraldine-bust .. ..L. Gwendolen Williams.

I 929-Robert Blake, Admiral and

General of the Forces of

Great Britain-statue, bronze

Frederick $W$. Pomeroy.

I 930-Mrs. Goff-bust .. .. .. Bertha L. Goff.

i93 I-At the Gates of the Past-

bronze relief .. $\quad . . \quad \ldots \quad \ldots$ Esther $M$. Moore.

I932-My Father-bust .. .. .. Arthur C. White.

i933-Alex. J. Hodge, EsQ.-bust .. Albert H. Hodge.

I934-The Kiss of Time: fragment

of a tomb-group .. .. .. F. Derwent Wood.

i 935-The Crown of Love-group.. William $R$. Colton.

"Though Heaven be near, I'm weary and would rest :

My comfort, joy - all whom I love the best-

Are of the earth. My soul's ideal, farewell!

Flesh is too frail to follow more the quest."

I 936-Honor, daughter of C. Fitzroy

Doce, Esq.-statue .. .. Henry C. Fehr.

i 937 - Eneas Leaving Troy-group Mortimer J. Brown.

I 938-Puma and Macaw-group ..John M. Swan, A.

I939-The Late Professor HuXley

E. Onslow Ford, R.A. 


\section{LECTURE ROOM.}

\section{SCULPTURE-(Nos. 1940-2056).}

i940-A Little Peasant .. L. Gwendolen Williams. I94I-"At A SOlemn music"-relief.. Arthur C. White. r942-Dead Indian-group, bronze Gutzow M. Borglum.

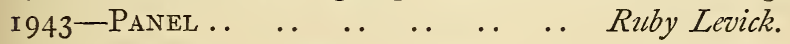
I944-Study of a Head-bronze .. John Treed.

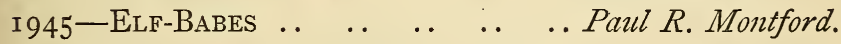
r946-PaRT OF a Design FOR A

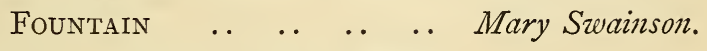
r947- EOLUS RULING THE FouR Winds .. $\quad . . \quad$.. $\quad .$. Edward G. Bramwel. I948-W. Lees McClure, Esq.-medallion, bronze .. .. J. Crosland McChure.

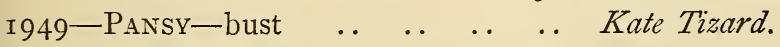
I950-J. Hugh Thomson, EsQ.-relief

Charles J. Pibworth. r95 I-St. Agnes' Eve-statuette .. Florence Parkinson. I952-HAND-MIRROR-silver .. .. Florence H. Steele. I953-Man's Head-bronze .. .. F. Derwent Wood. i954-Maxime-relief .. .. . . $\quad$ Charles J. Pibworth. 
1955-The Very Rev. Canon Joseph

McGrath-bust, bronze ..Joseph S. M. Carré. i 956-Case of Medals-silver.. George W. De Saulles. I957-An Aruimi Type-head, bronze Herbert Ward. i958-A Sentinel-head, bronze ..Andrea C. Lucchesi. I959-HAGAR—statuette, marble.. .. Albert Toft. ig60-Lord Avebury-bust .. .. Kathleen Shau. i 96 I-Out of REACH-group ..L. Gwendolen Williams. I962-IV. Rathbone, EsQ. : medal for Engineering, University College, Liverpool, obverse and reverse-bronze .. I963-Field-MaRshal LoRd Roberts OF KandahaR, V.C., \&C.bust, bronze $\quad . \quad \ldots \quad \ldots \quad . . \quad$ Albert Bruce-Joj.

I964-The Myrtle's Altar-statue, bronze .. $\quad . . \quad \ldots \quad$.. $\quad$ Andrea C. Lucchesi. I 965-REverie-statuette, bronze William J. McLean. I 966-S. Roberts, EsQ., Lord Mayor of Sheffield-bust, marble E. Onslow Ford, R.A. 1967-Tнову, son of Val. Prinsep,

Esq., R.A.-head, bronze Alfred Gilbert, R.A. ig68-Fisherman Hauling in a Net

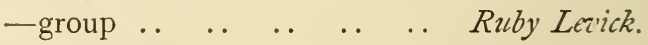

I969-IN MEMORIAM: portion of memorial to Horace Lot Bragg-

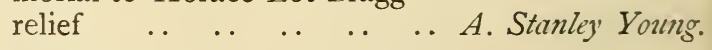
I 970-LAMIA-bust, ivory and bronze George J. Frampton, A. 
I97I-ART'S Fortune-statuette .. Lillian M. Morris. I972-E. M. P. Fisher, EsQ.-head,

bronze .. $\quad$. $\quad$.. $\quad$.. George J. Frampton, A.

I973-J. Pickering Pick, EsQ.,

F.R.C.S.-bust, marble .. Thomas Brock, R.A.

I974-"Anemone," the wind-flower-

statuette ..

I975- Aneas Fleeing From Troy-

$\begin{array}{lllllll}\text { group } & \text {. } & \text {.. } & \text {. } & \text {.. } & \text {. } & \text { Gilbert Bayes. }\end{array}$

I 976 - G. AGNEw, EsQ.-bust, bronze

E. Onslow Ford, R.A.

I977-Miss Rube-bust, marble .. George E. Wade. i 978 -Mrs. Rose Clarke Hartwell

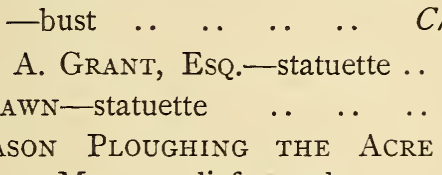

OF MaRs-relief, metal.. .. Gilbert Bayes.

i 982-Simplicity-head .. .. .. Honora M. Rigby. I983-The Duchess of Bresali-

bust, bronze .. $\quad . . \quad$.. ..J. Wenlock Rollins. I984-Horace Seymour, Esq., C.B.-

medallion, bronze .. .. George $W$. De Saulles. I985-A WEE WOMAN-head of a child

Henry A. Pegram.

I986-The Hammer - Thrower statuette .. $\quad$.. $\quad$.. $\quad$.. $\quad$.. Ruby Levick I987-Professor M. McHARdy-bust Kathleen Shaw. 
I988-Field-Marshal Lord Roberts

of Kandahar, V.C., \&C.-

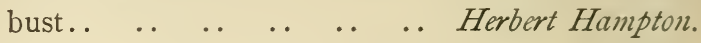

I989-MeMorial to the LATE General

Sir Henry Ponsonby-relief,

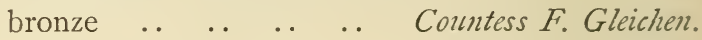

I990-Recumbent EfFigy of the LATE

Bishop of Wakefield.. J. Nesfield Forsyth.

I99I-Portrait of a Gentleman-

bust, bronze $\quad . \quad$.. $\quad$.. $\quad$ Charles L. Hartwell.

r992-Lilies-decorative panel .. George C. Beresford.

i 993-Slaves of the Ring-group .. Cecil Brown.

r994-Miss Emery-bust .. .. .. Lillian M. Morris.

i995-Decorative panel .. .. . . Florence H. Steele.

i996-Study of a Gnu-wax .. .. H. C. Christie.

I997-The LONely of Heart-bust,

bronze ..

r998-Margery-bust.. .. .. Charles J. Pibriorth.

I999-“A LIGHT OF THE PAST, GIVING

PLACE FOR LIFE AND LIGHT

TO COME"-bas-relief, carved

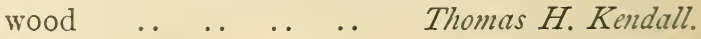

2000-H. M. Symons, Esq.-bust,

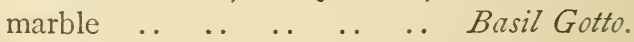

200I-LIONESS AND CUB ON THE ALERT

-group, bronze ....$\quad$.. Arthur J. Mills.

2002-David Young, EsQ.--bust .. Herbert Hampton. 
2003-BroOCH-bronze .. . . J. Crosland McClure. 2004-LEWIS WALLER, EsQ., as Brutus

-bust, bronze .. .. E. Onslow Ford, R.A. 2005 -Eros-statuette .. .. .. J. Crosland McClure. 2006-"PARTING IS SUCH SWEET SORROw"-group .. . . . S. Nicholson Babb. 2007 -The ChildreN OF Gilmour Brown, EsQ.-relief, beaten tin

$\begin{array}{lllll}2008 \text {-AlmS-Dish } & \ldots & \ldots & \ldots & \ldots\end{array}$.

bronze $\quad . \quad \ldots \quad \ldots \quad \ldots J$. Hanson Walker, jun. 2OIO-HEMANS MEDAL FOR LYRICAL Poetry, University College, Liverpool: obverse and reverse-bronze $\quad . \quad \ldots \quad$.. Charles J. Allen. 2OII-VICTORY - sketch for statue T. Crosland McClure. 2OI2-ROBERT BURNS-statuette .. Herbert Hampton. 2OI3-J. PASSMORE EdWARds, ESQ.bust, bronze .. .. .. .. Henry C. Fehr. 20I4-FATA Morgana - statuette, bronze, cire perdu .. . . . John $M$. Swan, A. 2OI5-ThE LATE DUKE OF DevoNSHIRE, K.G.-bust. Study for colossal bronze statue to be erected at Eastbourne.. .. .. W. Goscombe John, A. 20i6-The Annunciation-bas-relief John Broad. 2017-ImPRession FROM the GrEat Seal (seal and counterseal) George W. De Saulles 
20I8-The Prophetess of Fate-

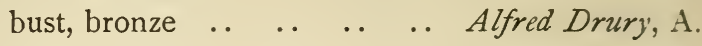
20I9-MatThew Maris, EsQ.-medal-

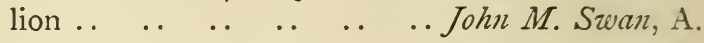
2020-Mrs. Henry Cust-bust $202 \mathrm{I}$-ARchishop Plunket. Sketch model of a statue to be erected in Dublin .. .. .. Hamo Thorneycroft, R.A. 2022-The Last Supper. Model of altar frontal executed in alabaster for Berkhampstead School Chapel

George W. I. Wilson. 2023-Guinevere and the Nestling

-statuette .. $\quad . . \quad \ldots \quad$ W. Reynolds-Stephens.

"... and after loved it tenderly

And named it nestling ; so forgot herself

A moment, and her cares;...."

Tennyson, 'The Last Tournament.'

2024-The Little Duchess-relief,

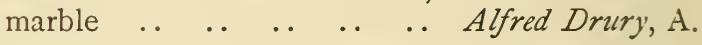

2025-His Grace the Duke of

Norfolk, K.G.-bust .. E. Onslow Ford, R.A. 2026-Music-bas-relief .. .. Septimus A. Bennett. 2027-Dr. F. PARkes-Weber, F.R.C.P.

- plaquette, obverse and re-

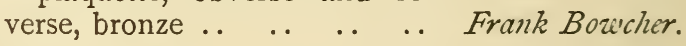
2028-The LATE William Morrisbust, bronze .. 2029-Wolfram Onslow Ford, EsQ. -head ....$\quad$.. $\quad .$. E. Onslow Ford, R.A. 
2030-The Storm-Wave-group .. Paul R. Montford. 203I-MODELS FOR WOOD PANELS,

Drapers' Hall.. .. .. .. Thomas Carter. 2032-RELIGION. Sketch model of figure for a public building .. $\quad . . \quad$ Edith Maryon. "Put on the whole armour of God."-Ephesians vi. Ir. 2033-The Birth of ApHrodite-in silver and translucent enamels Alexander Fisher. 2034-Ave Maria-coloured wax .. Nelia Casella. 2035-MARS-coloured wax .. .. Ella Casella. 2036--A Scholar-coloured wax .. Nelia Casella. 2037-On Sentry-bronze.. . . Charles L. Hartwell. 2038-Boys Fishing-group .. .. Ruby Levick. 2039-George Russell Cockerell,

EsQ.-bust, bronze.. .. George J. Frampton, A. 2040-Pumas and Turkey-group ..John H. M. Furse. 204I-Portrait of a Girl-relief .. Henry A. Pegram. 2042-Child with CAT-statuette .. Bertha L. Goff. 2043-Cordelia-bust, marble .. .. Honora M. Rigby. 2044-The Black Cat-relief, china Léon $V$. Solon. 2045-The Dragon-Slayer-group .. Gilbert Bayes. 2046 -

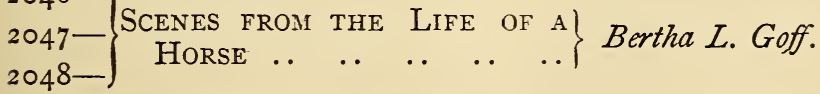
2049-C. J. Watson, EsQ.-bust ..Arthur G. Walker. 2050-"AND THEY WERE AFRAID" group 
205I-BAPTISMAL FONT: in memoriam

Johannis Botteville Thynne, son of the late Marquis of

Bath $\quad . \quad$.. $\quad . . \quad$.. Alfred Gilbert, R.A.

2052-Psyche aNd THE Casket OF

Venus-statue .. .. .. Horace Montford.

2053-TONB OF THE LATE LORD

Leighton, P.R.A. To be

executed in bronze and marble,

and placed in St. Paul's

Cathedral .. $\quad . . \quad$.. $\quad$ Thomas Brock, R.A.

2054-The Spearman-statue .. .. Fred. W. Pomeroj:

2055-EFFigy OF the LATE DeAN

VAUGHAN-marble. To be

placed in Llandaff Cathedral W. Goscombe John, A.

2056-Fortune-statue .. .. .. Henry A. Pegram.

In the Quadrangle.

2057-The Late MaharaJah OF

Mysore .. $\quad . . \quad \ldots \quad . . \quad$ E. Onslow Ford, R.A.

Corrections for the Press and all other communications should be addressed to "THE SECRETARI," and not to any official by name. 


\section{LIST OF THE EXHIBITORS, 1900. WITH THEIR ADDRESSES.}

*** The Figures at the end of the Exhibit rrs' Names and Addresses refer to the corresponding Numbers in the Catalogue.

ABBEY, E: A., R.A., Chelsea House, Tite-street, Chelsea, : and Morgan Hall, Fairford, Gloucestershire--5, 96, I47 ALMA-TADEMA, Sir L., R.A., I 7, Grove-end-road, N.W.-226 Ackermann, G., 25, Belsize-crescent, Hampstead, N.IW.-27 Acret, J. F., 43, Rosslyn-hill, Hampstead-I438, I457 Adams, C. J., 54, Station-road, Horsham, Sussex-1238, I271, I350 Adams, D., 7, James-street, Haymarket, S. W.-I I8, 665, 730 Adams, H. W., The Studio, Pierpoint-street, Worcester- 538 Adams, J. C., Ewhurst-hill, Guildford-280 Adams, J. T., St. Swithin's Manor, Park-road, Sutton-699, 767 Adams, WV. D., Dorchester, Wallingford-293 Adeney, IV. B., The Prelude, Coleman's Hatch, Hartfield, Tunbridge Wells-229

Affleck, W., 2, Leppoc-road, Clapham-park, S.W.-II68, I2II,

I 220, I 232

Aikman, W., I4, Burghley-road, Hornsey, N.-I7 I I, I 75I Albert, A. (Mrs. M.), 28, Alexandra-street, IVestbourne-gardenś, IV. $-516,417,977$

Alford, L. L., I 3, Sasson-road, Freemantle, Southampton-I6I I Allen, C. J., University College, Liverpool-I962, 2010 Allen, R. W., 62, Buckingham-gate, S.IT.-680, 96r Allen, T. W., Greencroft, Milford, Surrey-753, 790 Allport, C. L. (Miss), 3, Fulham Studios, 454A, Fulham-road, S. W. -5IO, 5II, 5 I2

Alma-Tadema, A. (Miss), I 7, Grove-end-road, N.W. -697 Althaus, F., Io, Mont le Grand, Exeter-343, I 2 I 
Anderson, C. G., Oratory Studios, I6, Fulham-road, S. W.-2 A ppleyard, F., i 8, Kensington-court-place-323, I 17 I

Archer, J., Haslemere, Surrey-986

Ardron, Dawson, and Howell (Messrs.), 6, Old Queen-street, IVestminster, S. W. - 1807

Armstrong and Wright (Messrs), 38, Grainger-street W., Newcastle-on-

Tyne-I698

Ashbee, C. R., 37, Cheyne-walk, S.W.-1840

Ashton, W., 59, Carlisle-st., Manningham, Bradford, Yorks-79I, 1525 Aumonier, J., I62, Adelaide-road, N.IV. -222

Aumonier, L. (Miss), 6, Dartmouth-park-road, N.W. -864 Austen, W. (Miss), 25, Mattock-lane, Ealing, W.-34, 937

Austin, R. C., I I 5, Gower-street, W.C.-I 775

Ayling, R. S., I9, Old Queen-street, IVestminster, S. W.- I 850

BOUGhton, G. H., R.A., West House, Campden-hill-road, Kensington, W.- I $86,35^{\circ}$

BROCK, T., R.A., The Studio, 30, Osnaburgh-street, Regent's-park,

$-1973,2053$

BELCHER, J., $A$., 20, Hanover-square, W.-I8I I, I8I 7, I8I8, I821 BRAMLEY, F., A., Ombersley, Droitwich-r 29, 236, 370, 645 BRETT, J., A., Daisyfield, Putney, S. W. - 743, 862, 865, 883, 890, 904 Babb, J. S., 12, Albert-square, Clapham-road, S. W.-1799, I819 Babb, S. N., Stamford-bridge Studio, Fulham-rd., S. IV.-1913, 2006 Bacon, J. H. F., 3, Compayne-gdns., South Hampstead-24, 302, I 243 Bagshawe, J. R., I3A, Sumner-pl., Brompton-rd., S.W.-26I, 27r, 59 S Bailey, A. E., Ferncliffe, Dern Gate, Northampton-7I, 430

Bailey, G., 43, Sinclair-road, West Kensington-park-1 724

Bailey, H., Holly-place, Mistley, Essex-I I 27

Bailey, H., Newark-on-Trent-I808

Baird, N. H. J., Holcombe, Dawlish-337

Baker, A. R., Ros-na-kil, Strand-town, Belfast-I I 75, I 334

Baker, B. (Miss), Sneed-cottage, Whetstone, N.-13IS

Baker, F. (Mrs. C.), Rosses Point, co. Sligo, Ireland-I I 20

Baldock, C. E., Ivy Cottage, Cropwell Bishop, near Nottingham-79 Baldwin, A., Annaly House, Upper Walmer-I634

Baldwyn, C. H. C., Stokesaye, Woolhope-road, Worcester-766, I25I Ball, W., The Cottage, Shackelford, Godalming-I2SI

Bamford, A. B., 30, Compton-road, Highbury, N.-I347 Barker, W., The Beeches, Ollerton, Newark-I4I, 61 5 , I039 Barnard, C. (Mrs. J. L.), The Gate House, West Drayton-I29I Barney, A. (Mrs.), I 53 Avenue Victor Hugo, Paris-I I 3 I 
Barratt, R., North House, Eton-avenue, N.W.-I2I9

Barraud, A., Bushey Heath, Watford-I 342

Barrett, K. (Miss), 5, Torrington-square, W.C. -383

Barrett, L., 23, Sheepcote-road, Harrow-I8I4

Barrow, E. I. (Miss), 22, Belmont-park, Lee, S.E.-II74

Bastida, J. S. y., Pasage de la Alhambra I y 3, Madrid-258, 536

Bastin, A. D., Runnymede, Dawn-view-road, West Worthing-I255

Bateman and Bateman (Messrs.), 8I, Edmund Street, Birmingham-

I 782, I 787

Bateman, S., I 7, South-place, Reading-rd., Henley-on-Thames-232 Bauerlé, A. (Miss), 59, Craven-park, Willesden, N.W.-I543, I 556 Bayes, A. W., 82, Fellows-rd., N.W.-940, I 532

Bayes, G., 82, Fellows-road, N.W.-1975, I981, 2045

Bayliss, E., The Wood House, Tettenhall, nr. Wolverhampton-406

Beach, E. G., I I, Park-hill-road, Haverstock-hill, N.W.-III6

Beacon, C., 4, Wentworth Studio, Manresa-road, Chelsea, S. W.-2007

Beadle, J.P., I 7 B, Eldon-road, Kensington, W.-685

Beaumont, F., Witchampton, Wimborne-89

Beaux, C. (Miss), I 7, Nassau-street, IV. -982

Beckingham, A., 47, Broadhurst-gardens, S. Hampstead-I002

Bedford, E. M. (Miss), 92, Boundary-rd., St. John's-wood, N.WW-469 Belcher, A.H., 8, \& 9, Martin's-lane, Cannon-st.,E.C.-I 77I, I 785, I890 Bell, A. G., 4, York-street, Covent Garden, W.C.-I 242, I 244 Bell, L. H. (Miss) Warwick Studio, South-end, Hampstead-I 503 Belloc, E. (Miss), 6, Bolton Studios, Redcliffe-road, S.W. -676 Benger, W. E., Batheaston, Crowborough, Sussex $-65^{8}$

Bennett, F. M., Alipore, Duppas-hill, Croydon-636

Bennett, S. A., 9, Fulham-park-gardens, Fulham-2026

Bennett, W. B., I38, Albert Cottages, Bushey, Herts-iog6, I I I I

Benson, N. (Miss), 78, Kensington-gardens-square, W.-I483

Benton, G. B., 3, Burlington House, Summer-row, Birmingham$1636,1643,1663$

Beresford, G. C., I, Haverstock-hill, N.W.-1992

Berkeley, S., Esher, Surrey-I055, I060

Berry, W. H. A., 23, Old Broad-street, E.C.-1685, I702, I703, I830 Betts, Ida (Miss), Abbots Langley, Herts-I 267

Beves, H. C. (Mrs.), 8, Holly-village, Highgate, N.-1432

Bigland, P., 32, Tite-street, Chelsea-282

Birch, L., La Pietra, Newlyn, Cornwall-659

Bishop, IV. F., I6, Welfield-place, Peel-street, Liverpool-57, I00 I

Blackburne, E. R. I., Tal an vean, Lilliput, Dorset-648

Blacklock, W. K., 2, Margaretta-terrace, Chelsea-I35I 
Bland, E. B. (Miss), 65, Glebe-place, Chelsea-318

Bland and Bown (Messrs.), North-park-road, Harrogate-1837

Blinks, T., I, Hill-road, St. John's-wood, N. W. - -39

Blomfield, A. C., 6, Montagu-place, Baker-street, W..-1795

Blomfield, R., New-court, Temple, E.C.-I 708

Blow, P. C., 7, London-road, St. Albans-1884

Boekbinder, J. M., II, Pratt-street, Camden-town, N. W.-I872

Bolingbroke, M. (Miss), I9, Girdler's-road, W.-I 570

Bolton, A. (Miss), I, Osborne-terrace, Clapham, S. W.-788, 1893 Bolton, A. T., 2, The Sanctuary, S. W.-1727, 1829, 1893

Bond, W. H., 2, Prestonville-road, Brighton-325

Bone, M., I36, Wellington-street, Glasgow-I 533

Boot, W. H. J., Markeaton, Well-road, Hampstead, N.W.-I I I 2

Borglum, G. M., Harlestone Villa, Mortimer-road, St. John's-wood, N.W.-1942

Bothams, W., Church-fields, Salisbury-I I 58

Bottamley, A., 7, Headingley-lane, Leeds-702

Bouguereau, IV. A., 75, Rue Notre Dame des Champs, Paris-297

Bowcher, F., 35, Fairfax-road, Bedford-park, W.-2027

Bowen, A. M. (Miss), 24, Victoria-street, Tenby, South Wales-352

Bowen, L. (Miss), 57, Campden-house-road, Kensington-45

Bowen, O., Studio, 5I, Cookridge-street, Leeds-35

Braby, N., Bushey Lodge, Teddington-48I, 686, 809, 855, 868

Pradley, G. M. (Miss), 7, Cambridge Mansions, Battersea-park, S. IV.

$-1654$

Bramley, IV., 58, Montpellier-road, Peckham, S.E.-235, 1008 Bramwell, E. G., Studio, Thornton-street, Brixton, S. W.-I947 Breakspeare, W. A., I, The Mall, Parkhill-road, Haverstock-hill, N.W. -740

Brewill aud Baily (Messrs.), Angel-row, Nottingham-I822, I87 I Brewtnall, E. F., 32, Fairfax.road, Bedford-park, W.-72, 263 Brickdale, E. F. (Miss), 30, Lansdowne-crescent, Notting-hill-795,

I 595

Bridgwater, H. S., Bushey, Herts-1673

Briggs and Wolstenholme (Messrs.), Blackburn-1742

Briggs, E. E., I02, Fellows-road, N.W.-I 204

Brinton, E. D. (Miss), I I, Queen's-gardens, Hyde-park, W.-7I2 Broad, J., 50, Westover-road, Wandsworth-2016

Brock, C. E., Arundine-house, Madingley-road, Cambridge-1045 Brock, W., Worcester Lodge, I, Mapesbury-road, Barnsbury, N.W.605

Brooke, J. W., 32, Basinghall-street, Leeds-I 83 
Brooks, F., I3A, Summer-place, Brompton-road, W. -389

Brooks, H. J., I 7A, Radnor-place, Hyde-park-square, W. -87

Brown, A., Carbis Bay, Lelant, Cornwall-149, IOI7

Brown, C., I4, St. John's-wood-road, N.W.-1917, 1993

Brown, E. (Miss), 4, Anglesea-road, Kingston-on-Thames-1465

Brown, E. A., 25 Villiers-road, Hertford, 6ro

Brown, H. H., I5, The Avenue, Fulham-road, South Kensington$3 \mathrm{I} 7,3 \mathrm{I} 9,647$

Brown, J. M., Strathairly-street, St. Ronan's-terrace, Edinburgh-1063

Brown, MI., 32, Great Ormond-street, Queen's-square, W.C. $-95^{8}$

Brown, M. J., Clarendon House, South Ealing, W.-1937

Browne, A. J. W., Ruan-Minor, R.S.O., Cornwall-499

Browne, G., 80, Finchley-road, N.W.-1260, I678

Browne, J. L., Woodbine Cottage, The Vale, Hampstead-1279, I349 Browne, T., Wollaton, Hardy-road, Westcombe-park, Blackheath,

S.E.-832, IOII, II 59

Brownscombe, J. (Miss), I2, Haymarket, S. W. -898

Bruce-Joy, A., The Studio, Beaumont-road, West Kensington-1963

Bruhl, L. B., Triplow, Romford-1297

Brutey, R. S., The Croft, Lee-on-the-Solent, Hants-886

Bryan, H. D., 38, College-green, Bristol-1694, I705

Brydon, J. M., 77, Newman-street, W.-I88I

Buchel, C. A., 2, Wychcombe Studios, England's-lane, Haverstockhill, N.W. $-607,609$

Buckell, F. W. A., 97, Gower-street, W.C.-1 740

Buckingham, E. (Mrs. C. Havers), 5I, Earlham-road, Norwich-I486

Buckman, P., 8, Portland-place, W. Kensington, W. -307

Bucknall, E. P., 9, Lime-hill-road, Tunbridge WVells-273, 1084, I 125

Bundy, E., 5, Adelaide-road, Haverstock-hill, N.W.-IO74

Burchett, A., 28, Willoughby-road, Hampstead-349

Burgess, E. M. (Miss), I8, Addison-road, Walthamstow-Ir 30

Burne-Jones, Sir P., Bart., 9, St. Paul's Studios, Hammersmith - 396, 472 Burridge, F., 6, Blackburn-terrace, Liverpool-I 529

Burton, A. P., 2A, Joubert's Mransions, Jubilee-place, Chelsea-25I, 304,390

Bush, R. E. J., 5, Camden-terrace, Cotham, Bristol-I56I, I58I

Bushby, T., Victoria Lodge, Currock, Carlisle-I 208

Butler, M. A. (Miss), 6o, St. George's-square, S.W.-1329

Butler, Wilson, and Oglesby (Messrs), I2, East-parade, Leeds-1776,

I806, 1876

Buxton, R. H., Elm Cottage, Wimbledon-common, S.W.-398 
COOPER, T. S., R.A., 42, Chepstow-villas, Bayswater, W.-620, $626,631,632$

CROFTS, E., R.A., Burlington House, Piccadilly, W. -82

CLAUSEN, G., A., Widdington, Newport, Essex-4, 185, 291, 315 , 455,780

COPE, A. S., A., Little Campden House, Gloucester-walk, Kensington, W.-182, 194, 197, 262, 496, 591

CROWE, E., A., 27, Charlotte-street, Portland-place-6r 3, 894

Cafe, T. W., 46, Clifton-hill, St. John's-wood, N. W. $\rightarrow 16$

Caffieri, H., 30, Great Russell-street, W.C.-1154

Calthorp, D. C., 64, Charlotte-street, Fitzroy-square-405

Calvert, F., 39A, Queen's-square, Bloomsbury, W.C.-1252

Cameron, D., I49, Warrender-park-road, Edinburgh-58

Cameron, M. (Miss), I I, Melville-place, Edinburgh-960

Canziani, L. S. (Mde.), 3, Palace-green, Kensington, W.-I I I

Cappon, T. M., 30, Reform-street, Dundee-1874

Cardon, C., I, Camden Studios, Camden-street, N. W.-429, 706

Caröe, W. D., 8A, Whitehall-place, S.W.-1820, 1865, I889

Carpenter, A., Hogarth Studio, 64 Charlotte-st., Fitzroy-sq., W.-I 887

Carré, J. S. M., 66, Glebe-place, Chelsea, S.W.-1955

Carter, F. T., I8, Nuns-street, Newcastle-on-Tyne-357, 981

Carter, F. W., I 2, Clarendon-road, Holland-park, W.-I3 I

Carter, H., I 2, Clarendon-road, Holland-park, W. -896

Carter, T., 63, Westminster-bridge-road, S.W.-2031

Cartlidge, G., I4, Snow Hill, Hanley, Staffs. - 994

Casella, E. (Miss), I, Wetherby-road, S. W.-2035

Casella, N. (Miss), I, Wetherby-road, S. W. $-2034,2036$

Catlow, G. S., The Studio, Market-place, Leicester-I I 84

Cauty, H. H., 24, Victoria-road, Sutton -945

Cave, W., 8, Old Burlington-street, W. -1843

Chadwick, E. A., Hampton-in-Arden, Birmingham-1312

Chambers, N. (Mrs.), Currabinny, Epsom-1436

Charles, J., East Ashling House, Chichester-618, 1053

Charlesworth, A. (Miss), Nutfield, Surrey-I266, I285

Charlton, E. M. (Mrs. J.), Hewelsfield, The Grange, Gunnersbury, IT. $-1462,1471$

Charlton, J., 6, William-street, Albert-gate, S.W. -956

Cheston, H., and J. C. Perkin (Messrs.), 5, Union-court, Old Broadstreet, E.C.-1816

Chettle, E. M. (Miss), Sharnbrook, Bedfordshire-I 235

Christian, C. L. (Miss), 38, Cheyne-walk, Chelsea-347, 410

Christie, H. C., St. Alban's, Caterham Valley-1996

Christie, J. E., I81, King's-road, Chelsea-104, 565 
Clacy, E. (Miss), 39, Fitzroy-road, Primrose-hill, N. IV.-345

Clark, C., I4, Jubilee-place, Chelsea, S.W.-I645

Clark, E. O., 76, Finsbury-pavement, E.C.-I761, I 762

Clark, E. P. (Miss), 9, Queen Anne's-gardens, Bedford-park, Chiswick-127

Clark, James, Io, Victoria-grove, Fulham-road, S. IV. -38

Clark, Joseph, Wendouree, Pinner-road, Harrow-6or, 704

Clark, J. W., Westoe-road, South Shields-I 309

Clifford, H. C., 57, Addison-gardens, Kensington, W. -490

Clink, E. L. (Miss), c/o Reeves and Son, High-street, KensingtonI 485,1492

Cockerell, S. P., 35, Phillimore-gardens, W.-404

Cockram, G., Rhos Neigr, Ty Croes, Anglesea-1206, I245

Cohen, E. G. (Miss), I5, St. Loo-mansions, Cheyne-walk, Chelsea, S. IV. -305

Cohen, M. A. (Miss), 18, Tregunter-road, The Boltons, S.W.-r73, 265,462

Cole, H., I5, Nicholson-road, Walthamstow, E.-r590

Cole, R. V., 9, Campden-hill-square, W. -439

Collcutt, T. E., 36, Bloomsbury-square, W.C.-1766, I780, r78 I

Collier (Hon. J.), North House, Eton-avenue, N.W.-I7, 4I9, 957

Collins, C., I5, Arundel-road, Dorking-418, 46r, 828

Collyer, K. W. (Miss), The Fosse, Leicester-I 474

Collyer, M. (Miss), Tedworth Studios, Smith-terr., Chelsea, S. W. -448

Colton, W. R., Eaton Studio, Eaton-terrace, St. John's-wood-I935

Comfort, A., 227, Hyde-park-road, Leeds-I 534, I667

Conder, L. (Miss), Warwick Studio, South-end, Hampstead-I434

Connard, P., 23, Musgrave-crescent, Fulham, S. W.-I628, I650, I665

Constant, R., 27, Rue Pigalle, Paris-I035, IO4I

Cook, E. W., 20, Fairlawn-park, Chiswick, W.-I302

Cook, H. M., Corrie, Isle of Arran, viâ Ardrossan, Scotland-I20

Cook, N. E. (Miss), 6o, Alexandra-rd., South Hampstead, N. W.-I388

Cooke, A. C., Steele's Studios, Haverstock-hill, N.W.-216

Cooke, I., Kirkstone, Liscard-park, Liscard, Cheshire-I 178

Cooke, J., 2, Trafalgar Studios, Manresa-rd., Chelsea-203

Cooke, W. C., 2r, Mead's-rd., Westbury Avenue, Wood-gr., N.-827

Cookesley, M. M. (Mrs.), 7, Cromwell-place, S.W.-9I4, 975

Coop, H., Conway, North Wales-I228

Cooper, A. W., 4, Manor-road, Twickenham-1605

Copping, H., 30, Montague-road, Hornsey, N.-I608

Corbet, E. (Mrs. M.R.), 54, Circus-road, St. John's-wood-502, 770, 835 
Corbet, M. R., 54, Circus-road, St. John's-wood, N. W. -979

Corlette, H. C., 2, New-square, Lincoln's-inn, W.C. - I 765, I 769

Cormack, M. (Mrs), 6, Pomona House Studio, New King's-road, Fulham-road, S.W. $-718,720$

Cornish, W. P., I6, Grand-parade, Finchley-road, N.W.-I 207

Cotman, F. G., Arts Club, 40, Dover-street, Piccadilly, IW. $-727,736$, 741,764 .

Coutts, H., Hammerbank, Winderm re-I I23, I199

Cowieson, A. M. (Miss), Rose-cottage, Ducldington, Edinburgh -724 Cowper, F. C., 38, Barrow-hill-road, St. John's-wood, N.W.-6I4,

745,1597

Cowper, G. T. (Miss), I90, Gloucester-terrace, Hyde-park-I460 Cowper, T., 7, King Edward's-road, Hackney-253, 474.

Cox, L. C., Oakfield, St. James'-road, Tunbridge-wells-657

Craig, F., 26, Willow-road, Hampstead, N.W.-I6I9

Crane, L. F., I3, Holland-street, Kensington, W.-1910.

Crane, T., 7, Coleridge-road, Crouch-end, N.-1296

Crick, M., 4, Chester-place, Norwich-1609

Cridland, H. (Miss), 3, Sparrows Herne, Bushey, Herts-I32

Crocket, H. E., I I2, Torriano-avenue, N.W.-I65I

Cullen, F., Latchmoor, Gerrards-cross, Slough-1429, I 50 I

Cundy, A. L. (Miss), IO4, Abbey-road, N.W.-1439

Cuneo, C., 9, Rue Campagne Première, Paris, Montparnasse-I 579, I 594 Cutler, T. W., 5, Queen's-square, Bloomsbury, W.C.-1684

DAVIS, H. W. B., R.A., Glaslyn, Rhayader, Radnor-16, 122, 227, 816,933

DICKSEE, F., R.A., 3, Greville-place, Maida-vale, W.-I67

DRURY, A., A., 6, Gunter-grove, Chelsea, S. W.-20IS, 2034

Da Costa, J., 9, Sussex-villas, Kensington, WT.-134, 237

Daffarn, W. G., I4, Campden-hill-square, W.-943

Dakin, J., Gleenlee, Marmora-road, Honor Oak, S.E.-I I 46

Dalgliesh, T. I., 9, Claremont-road, Folkeston - I 625

Dallmeyer, R. (Miss), c/o General Thomas, C.B., 25, Eldon-road, Kensington, W. -90 I

Dalziel, O., Wooler House, Beltinge Road, Herne Bay-936

Davidson, W. R., 28, Victoria-street, S.W. $-I 682$

Davis, J. B., 8, Cotleigh-road, West Hampstead, N.W. -563

Davis, L., 49, South-hill-park, Hampstead-1275

Davis, S. G., I, Queen's-road Studios, St. John's-wood, N.W.-77I

Davis, V., 5. Langham Chambers, Portland-place, W.-74, 907

Davison, MI. D. (Miss), Eyot Cottage, Chiswick-1392, I393, I394, I 395 
Davison, T., 28, Great Ormond-street, W.C.—I687, I695

Dawber, E. G., and Whitwell (Messrs.), 22, Buckingham-street, Adelphi, W.C. -1800

Dawson, R. A., 63, New King's-road, Fulham-1 I65, I 357

De Lacy, J. C., Sunnydale, 32, Westwell-road, Streatham-common, S. W. - I632

De Saulles, G. W., 31, Fairfax-road, Bedford-park, W.-1956, I984, 2017

Dean, F., Tennyson Villa, Tennyson-road, Harpenden-4I4, 695

Deanes, E., 7, Dilke-street, Chelsea-embankment-152 I

Dearle, J. H., The Retreat, Pirbright, Surrey-582, I 167

Dell, H. L., Onslow Studios, I83, King's-road, Chelsea-1052

De Ville, V., Compton, near Wolverhampton-786, 863

Dick, R. T., Cliff Castle Cottage, Newlyn, Cornwall-368

Dicksee, H., Oak House, Kidderpore-avenue, Hampstead-I548, I 564, I 578

Dicksee, J. R., Sherpore House, Platt's-lane, Hampstead, N. IV.-693

Dickson, IV., Tadley, Basingstoke-643

Dixon, A. A., 4, Gatcombe-road, Tufnell-park, N.-344

Dixon, H., Shoreham, Sevenoaks-I I03

Dixon, P., Trevena, Bournemouth-I I43

Dobie, J., Io, Grazebrook-road, Stoke Newington, N.-- 568

Dobson, A., The Cottage, Edwardes-square, Kensington-358

Docharty, A. B., 3, Jane-street, Blythswood-square, Glasgow-I 7 I

Dockerill, M. (Miss), 5, Meadow Studios, Bushey, Herts-I278, I502,

I5I9

Dollman, J. C., Hove-house, Newton-grove, Bedford-park, W.-40, 514 Donkin, A. E. (Miss), Englefield-green, Staines-i 284

Douglas, E., Fox-down, Findon, Sussex-1076

Dowdall, E., 79, Newman-street, W. -732

Downing, D., Fulham House, Fulham, S.W.-208

Drage, J. H., Tamworth-road, Croydon-1 I 62

Draper, H. J., I5, Abbey-road, N.W.-290, 628, 955

Drew, H. J., 84, Brigstock-road, Thornton-heath, S.E.-I455

Drummond, R. (Miss), 267 , Camden-road, N.-I477

Drysdale, J. (Miss), IO2, Westbourne-terrace, Hyde-park, W. - I 259

Duassut, C., I4, Lynmouth-road, Stamford-hill, N.-I250, 1277, I 286

Dudley, A., 3I, Lansdowne-road, Notting-hill-959

Duncan, E. (Miss), 33, Priory-road, Kilburn-421, 529

Durham, M. E. (Miss), 20, Ellerdale-rd., Fitzjohn's-avenue, N. W.-759

Dutton, J. F. H., The Nook, Hamilton-street, Hoole, Chester-642 
Duthie, S., Thornhill, Cults, Aberdeen-244, 656, 908, 95 I

Du Val, E. T., The Brambles, Great Marlow-I 12

Duvergé, Y. K. (Mde.), Anjou, Clarcmont-road, Surbiton-I44I

EAST, A., A., 2, Spenser-sreet, Victoria-street, S.IV.-92, 268, 544, II93

Earl, M. (Miss), 3, Bloomfield Studios, Bloomfield-place, S.W.-9o Earp, V., Io, Albert Mansions, Crouch-hill, N.-I 257

Eastlake, C. H., 6, Clarendon-street, Warwick-square, S. W.-289

Eden, W. D., 76, Adelaide-road, N.W.- 1648

Edmonds, C. (Mrs.), Mote Lodge, Heavitree, Exeter-I344

Edmunds, N. M. H. (Miss), 23, South Croxted-road, West Dulwich, S.E. -1437

Edward, A. S., 46, Fountayne-road, Stamford-hill, N.-793

Edwards, G. Hay, Roselea, Lower common, Putney, S. W.-1256:

Edwards, G. Henry, 4, Camden Studios, Camden-street, N. W. - I 253 Edwards, M. (Mrs. A. Brown), Carbis Bay, Lelant, Cornwall-1026 Edwards, M. E. (Mrs. Staples), I46, Lancaster-road, Notting-hill, W. $-792,812$

Elias, A. (Miss), 9, Vicarage-gardens, Kensington-567, 1077

Ellis, C. W., Lindsay House, Bishop's Stortford-IOI9, I090

Ellis, E. C. (Mrs.), 56, Bedford-gardens, Kensington, W.-I463

Ellis, T., Westcott, Dorking- 1565

Elwood, G. M., 55, Alexander-road, Upper Holloway, N.-I 757

Emms, J., Lyndhurst, Hants-56

Emsley, W., Grosvenor Chambers, I6, Dean's Gate, Manchester- $\delta ; 2$ Emslie, R. M. (Mrs. A. E.), Otford, Sevenoaks-1396, I397, I398,

I399, I400, I40I, I402

Enderby, S. G., 3I, St. James's-square, Holland-park, W.-165

Evans, H. E., 5, Warwick Studios, Kensington, W.-1272

Eve, G. W., 573, High-road, Chiswick-I 539

Evershed, A., Fishbourne, Chichester, Sussex-807

Every, G. H., Dovedale, The Hyde, Hendon, N.W.-I672

Evison, G. H., 21, Camden-road Studios, N.W.-I627, I656

Eyre, J., 26, Bridge-road-west, Battersea-park, S.W.-I360

FILDES, L., R.A., I I, Melbury-rd., Kensington, W.-3I, S5, I 54, 274 FORD, E. O., R.A., 62, Acacia-road, N.W.-1939, 1966, 1976, 2004, 2025, 2029, 2057

FRITH, W. P., R.A., I I4, Clifton-hill, St. John's-wood, N.W.-\$93 FORBES, S. A., A., Trewarveneth, Newlyn, Penzance-6, 334, 875, 
FRAMPTON, G. J., A., 32, Queen's-road, St. John's-wood, N.W.I970, 1972, 2039

Faed, J. (jun.), I, Clifton-hill Studios, Abbey-road, N.W.-86r, 9I5, 1085

Fahey, E. H., 28, Dawson-place, Bayswater, W. -954

Falkner, H., 24, West-street, Farnham, Surrey-I760, I907

Fanner, A. (Miss), The Boltons, Grove-park-terrace, Chiswick, S.IW.

$-465,924$

Fantin-Latour, H., 26, Golden-square, IV.-I35, 837

Farquharson, D., Sennen, Penzance-I3

Farquharson, J., Migvie Lodge, Porchester-gardens, W.-256, 339, 698 Fehr, H. C., 6 \& 8, The Avenue Studios, 76, Fulham-road, S.IV.-

I922, 1936, 2013, 2028

Fernley, E. H. (Miss), I7, Alma-square, St. John's-wood-I430

Fidler, G., Teffont Magna, near Salisbury-I293, I3I 7, I320

Field, H., I, Langham-chambers, IV.-I908

Finnie, J., Tywyn, Llandudno-624

Fisher, A., I 7, Warwick-gardens, Kensington, W.-I359, 2033

Fisher, A. E., The Pines, Freemantle, Southampton-I30I

Fisher, A. H., 164, Piccadilly, IV.-I343, I 536, I 54 I

Fisher, J. (Miss), Walton Rectory, Burton-on-Trent- 988

Fisher, J. H. V., The Red Cottage, Shamley-green, Guildford-34I

Fisher, M., Widdington, Newport, Essex-283, 413, 1023

Fisher, P. H., Butt's Lodge, Brentford -679

Fisher, S. M., I2, Orme-square, W. $-84,146,587$

Fitzgerald, F. (Miss), c/o Mrs. Bishop, I6, Welfield-place, Peel-street, Liverpool-978, 987

Fletcher, A. G. (Miss), I9, Parliament-hill, Hampstead, N. W.-I380,

I $381, I_{3} 82,1482$

Fletcher, B. and Sons (Messrs.), 29, New Bridge-street, E.C.-I722,

1772,1825

Fleuss, O., 3, Grove Studios, Hammersmith-I853

Flower, C. E., 29, Elmer's-end-road, Anerley, S.E.-1316, I353

Flower, N., I 7, Holland-park-road, Kensington-98

Forbes, E. (Mrs. S. A.), Trewarveneth, Newlyn, Penzance-I IO2

Ford, H. J., 4, Westbourne-street, Hyde-park-785, I635, I664

Ford, R. O., 62, Acacia-road, St. John's-wood, N.W.- 535

Ford, W. O., 62, Acacia-road, N. IV. $-533,600$

Forster, J. W., I 2, South-parade, Bedford-park, W.-I I69

Forsyth, J. D., Studio, 325, Finchley-road, N. W.-I813

Forsyth, J. N., Studio, 325, Finchley-road, N.W.-I990

Fosbrooke, L., Ravenstone, Ashby-de-la-Zouch-I20I 
Foster, A. J., 43, Broadhurst-gdns., South Hampstead, N. W.-382, 810 Foster, D. (Miss), Beechwood, Halton, Leeds-1468

Foster, F., 8, Duke-street, Adelphi, W.C.-1883

Foster, G., Beechwood, Halton, Leeds-6r, 438, i 7 \%

Fothergill, C. W., Cranbrook, Kent-1355

Fowler, E. M. (Mrs.), Donington Rectory, Spalding-843

Fox, E. R., Wingham, near Dover-879

Fox, S., 3S, Markham-square, S.W.- 858 , 1263

Francis, E. (Miss), Edenham, Shaftesbury-rd., Southsea-939, I300

Francis, T. E., 23, Canonbury-park-south, Canonbury, N. -877

Franck, H. (Miss), 34A, Finchley-road, N. W.-1029

Fraser, J., Studios, 21, Camden-road, N.W.-1036, I080

Freeman, W. (Miss), Newlyn, Penzance-I248

Freyburg, F. P., Hillside, Halland, Sussex-205

Friedenson, A. A., I6, Bankside-street, Roundhay-road, Leeds -723

Fripp, I., Kennington Studios, Princes-square, S.E.-II 88

Fuller, E. G., Dunvegan, St. Ives, Cornwall-18

Fulleylove, J., I, Langham-chambers, Portland-place, WV. -768 , 8 I I

Fullwood, J., Studio, Meadowside, Slinfold, Sussex-1544, I546, 1553

Furniss, M. (Miss), West-hill, Epsom-353, I290

Furse, J. H. M., 5, The Avenue, Fulham-road-2040

GILBERT, A., R.A., M.V.O., I6, Maida-vale, W.-1957, 2020, 205 I GOODALL, F., R.A., 62, Avenue-road, Regent's-park, N.W.I8I, $58 \mathrm{I}, 586,650$, 1040

GOW, A. C., R.A., ${ }^{15}$, Grove-end-road, N.W. -198

GRAHAII, P., R.A., 93, Ladbroke-road, Notting-hill, W.--49, 206 GREGORY, E. J., R.A., 8, Greville-place, Maida-vale, W.-I 30, 201 Gallon, R., 32, Alma-square, St. John's-wood-I02I

Gandy, H., IOI, Chelsea-gardens, S. W.-340

Gardner, S., 35, Gloucester-crescent, Regent's-park, N.W.- -824

Gardner, W. B., Albion-chambers, 6o, Haymarket, S.W.-1676

Garland, C. T., Chyoone-grove, Newlyn, Penzance -900

Garland, V. T., St. Valery, Winchester-823, S50, 866, S73, 903

Garman, 11. (Miss), Great Barr, Birmingham-1473

Garratt, A. P., 27, Ashworth Mansions, Elgin-avenue, Maida-vale1587,1601

Garry, J. J., 30, Torrington-square, W.C. -1716

Garstin, N., 4, Wellington-terrace, Penzance- 554

Gascoyne, G., Bapchild-court, Sittingbourne--23\$

Gaskell, G. A., I, West End Mansions, West Hampstead, N.W.-S97

Gaskell, P., 35, Acacia-road, St. John's-wood, N.W.-717, 773 
George and Yeates (Messrs.), I8, Maddox-street, W.-I680, I68I Gibbs, P. W., 8, Albert Stadios, Albert-bridge-road, S.W.-I64 Gibson, M. J. (Miss), 77, Blenheim-crescent, Ladbroke-grove, W.I42I, I422, I423

Gibson, W. H., Clarke, \& Warwick (Messrs.), The Rookery, Wembley, Middlesex-I 7 I7

Gihon, A. D., 59, Avenue de Saxe, Paris-294

Gilchrist, P. T., Danehurst, Morley-road, Southport-44r

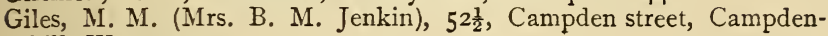
hill, W.-I9I4

Giles, W., 68, London-street, Reading-1607

Glasby, W., 20, Church-row, Hampstead-1707

Glazebrook, H. de T., 76, Elm-pk.-rd., Chelsea, S. W.-369, 394, 6I 7

Gleichen, F. (The Countess), St. James's Palace, S. W.-I989

Glendening, A. A., 6, Sandbourne-road, Brockley, S.E.-3, 944

Glennie, F. F., 16, Clifford's Inn, W.C.-1713

Glindoni, H. G., The Studio, Chadwell Heath, Essex-634, 637, 669

Gloag, I. L., 54, Elm-park-gardens, S. W.-495, 557

Godward, J. W., 410, Fulham-road, S.W. -820

Goetze, S., 6A, Abercorn-place, N.W. -426 , 593, IoI 5

Goff, B. L. (Miss), Ashdene, The Avenue, Lee, S.E.-1930, 2042, 2046, 2047, 2048

Goff, F. E. J., 27, Lynett-avenue, Clapham-common, S. W.-I274, 1283,1307

Goldsmith, H., 63, Faulkner-street, Manchester-I735

Goldthwaite, H., The Gables, South Norwood-hill, S.E.-52, 899 Goodall, T. F., The Homestead, Oulton Broad, Lowestoft -356 Goodman, M. (Miss), 7, Addison-crescent, Kensin Goodman, R., 6, Bedford-gardens, Kensington, W.-51 5 Goodwin, A., 7, Mcntpelier-terrace, Ilfracombe-463, 575, I 276 Goodwin, H., 4, Lisburne-crescent, Torquay, Devon-I095 Gordon, H. H., I23, Cannon-street, E.C.-1 788

Gordon, S. Elm Studio, 42, Freke-road, S. W. $-75^{6}$

Gore, W. H., 3, Dounington-square, Newtury-800, 1089

Gosnell, D. H., The Mill House, Goudhurst, Kent-694, 1025

Gotch, T. C., Penwith, Shottermill, R.S.O.-I I, 392

Gotto, B., 82, Drayton-gardens, South Kensington-2000

Gould, A. C., 3, Endsleigh-street, Tavistock-square, W.C.--88o Goyder, A. K. (Miss), 88, Gt. Horton-rd., Bradford, Yorks-I6 2 Grace, H. E. (Miss), 54, York-road, Hove, Brighton-692 Grace, J. E., 26, Woodstock-road, Bedford-park, W.-1072 Graham, T., 96, Fellows-road, N.W.-393 
Graham, N., Merrow, Guildford-I236

Gray, M. F. (Miss), 2, The Boltons, South Kensington, S. W.-Ior Greaves, W., I8, Park-lane, Leeds-Ios8

Gregory, E. (Miss), 22, Adamson-road, Swiss-cottage, N.W.-1658 Green and Abbott (Messrs.), 473, Oxford-street, W.-I692

Green, E. M. (Miss), 7, Rossetti House Studios, Rossetti-gardens, Chelsea, S. IV.-I 447

Green, R. C., Widdington, Newport, Essex-457, 784 Green, W. C., 7, John-street, Bedford-row, W.C.-1794, 1828

Greenhead, H. T., I 5, Gloucester-road, Regent's-park, N.W.-I674 Greenwood, B. (Miss), I2, Balmoral-rd., Willesden-green, N.W. -783 Grey, E. F. (Mrs.), 22, Blackett-street, Newcastle-on-Tyne-I33 $\mathrm{\gamma}$ Gribble, B. F., I2, Trafalgar Studios, Manresa-rd., Chelsea-I048, I05I Grier, L., The Foc'sle, St. Ives, Cornwall-649

Griffiths, W. J., Glencairn, Kyrle-rd., Clapham-common, S.W.-1718 Groome, W. H. C., 78, Coldershaw-road, Ealing, W.-1136, I I38 Grundy, C. C., Plas-Mawr, Conway-I25

Gurney, E. T., 43, Ampthill-square, Hampstead-road, N.W.-1649

HERKOMER, H., von, R.A., Lululaund, Bushey, Herts-1 5, 180, $333,537,549,668$, I 356, I 36 I

HOOK, J. C., R.A., Silverbeck, Churt, near Farnham-212, 218, 269,279

HACKER, A., A., 7, Cavendish-buildings, Old Cavendish-street, W. $-309,434,545,673$

HEMI, C. N., $A$., Churchfield, Falmouth-142, I I6I, I I82, I2 I8 HUNTER, C., A., I 4, Melbury-road, Kensington, IV.-IIO, 646 Hack, M. S., 54, Doughty-street, W.-I 70I

Haddan, P., 3, Norfolk Mansions, Lithos-road, South Hampstead, N. W. -923

Haddon, T., 58, Millbank-street, Westminster, S. W.-200, 666 Hagarty, M. S. (Miss), 26, Christchurch-road, Streatham-hill, S.W.I IOS

Hague, A., Delganwy, Llandudno-202, 556

Haigh-WVood, C., 45, Broadhurst-gardens, South Hampstead-570, 992 Hale, E. M., Shackleford, Godalming, Surrey-521, 682

Hall, Cooper and Davis (Messrs.), 2I, Old Queen-street, Westminster, S. W. - I 732

Hall, F., 6, Castle-street, Liverpool-493, 905

Hallowes, S. M., Heath Fern Lodge, Heathside, Hampstead-3I I

Hamilton, J. McL., 6, Grove-end-road, St. John's-wood-IO49

Hamilton, V. M., 5, Abbey-gardens, N.W.-I36 
Hammond, R. G., I6, Essex-street, Strand, W.C.-1827

Hammond, T. W., Ravenscar, Derby-road, Nottingham-I592, 1600 I6I6

Hampton, H., I8, St. Anne's Villas, Holland-park-avenue-I9I6, I988, 2002, 2012

Hanhart, M., 47, Constantine-road, Hampstead-6o3

Hankey, M. L. (Mrs. W. L.), 404C, Fulham-road, S. W.-I4I 7, I4I8,

I419, I420

Hankey, W. L., 404C, Fulham-road, S. W. -234, 277

Hansard, F. (Miss), 5, Stratford Studios, Stratford-road, W.-446

Harcourt, G., Bushey, Herts-276

Harcourt, M. L. (Mrs. G.), Bushey, Herts-I 306

Harding, M. (Miss), I39, Alexandra-road, St. John's-wood, N. IV.920, 999

Hardman, M. J. (Mrs.), Thorntons, Northaw, Herts-I497

Hardy, D., Eccentric Club, Shaftesbury-avenue-738, 926

Hardy, H., Io, Abbey-road, St. John's-wood, N.W. -684

Hardy, N. (Miss), Io, Abbey-road, St. John's-wood, N.W.-22

Hardy, N. H., Albert Studios, Albert-bridge-road, S. W.-I I42

Hare, H. T., I3, Hart-street, Bloomsbury, W.C.-I8Io

Harley, H. E., 8, Monmouth-road, Bayswater, W. -853

Harms, E. M. (Miss), 23, Carfax, Horsham, Sussex-1280

Harrand, L. (Miss), I I, Alwyn-square, Canonbury, N.-1626

Harris, M. (Mrs.), 79, Ware-road, Hertford-I547

Harrison and Ward (Messrs.), 66, Victoria-street, S. W.-I 72I, I 747

Harrison, A. J. (Miss), Studios 2, I7 I, Stanhope-street, Regent's-park,

W. -1442

Harrison, D., 6, St. Paul's Studios, Talgarth-road, W.-36I

Harrison, G. E., I, Boyle-street, Savile-row, W.-I49I

Harrison, G. L., IOI, Comeragh-road, West Kensington-757

Harrison, S. C. (Miss), 30, Cheyne-row, Chelsea, S.W.-1470

Hart, A., 32, York-road, Hove, Brighton-354

Hartwell, C. L., 8, Manville-road, Upper Tooting, S.W.-1978, I99I,

2037

Haughton, B., Summer-hill, Benenden, Kent-857

Havers, Val, 99, Great Titchfield-street, W.-1003

Haviland, F. A., 205, Maida-vale, W.-23I, I489

Hay, J. H., Pool-buildings, IO, South Castle-street, Liverpool3 I2, I 542

Hay, P. A., I 7, Holland-park-road, Kensington, W.-696, 953, I240

Hayes, C., Woburn-hill, Addlestone-316

Hayes, E., I9, Streatley-road, Brondesbury, N.W.-7, 638 
Hayes, G. E. (Miss), 40, St. Charles-square, N. Kensington, W.$1562,15: 2$

Hayes, H., I I 5 , Windsor-road, Ilford, E. -689

Hayllar, J. (Miss), Redholme, Cambridge-road, Bournemouth-450

Haynes, A. S., 56, Glebe-place, Chelsea- 363

Hayward, E. C. (Mrs. A. F. W.), Ashdene, Shawford, Winchester-834 Heath, D., Io, Fitzroy-street, W.C. -573

Heath, M. A. (Miss), 70, Grosvenor-road, Pimlico, S. W. -991, 1505

Hedley, R., I I, New-bridge-street, Newcastle-on-Tyne-518, 980, 1082 Hennell, A. R., 8 and 9, Essex-street, Strand, W.C.-1 768

Henniker, A. L. (Miss), 25, Beechcroft, Upper Tooting-25

Henry, J. L., I0, Warwick-place, Maida-hill, W.-IO2, 259 Henshall, J. H., St. Luke's, Southport-776, 844

Henton, G. M., Charnwood, Victoria-road, Leicester-I I 53

Herdman, D., St. Bernard's Tower, Bruntsfield-crescent, Edinburgh910

Herkon:rr, H. G., 6, William-street, Lowndes-square-I068

Heron a1.d Bellairs (Messrs.), 27, Fitzroy-street, Fitzroy-square, W.C. $-1823$

Hester, E. G., I I4, London-road, St. Alban's, Herts-I670

Hetherington, I., 4, Steele's Studios, Haverstock-hill, N. IV. -7I 3

Hicks, G. E., Odiham, Hants-476, 995

Hickson, M. (Miss), c/o Mrs. Fraser-Nash, 136, Haverstock-hill, N.W.-I33

Heydemann, W., The Studios, 39, St. John's-wood-road-park, N.W.I 537, I 538, I 549

Higgins, E. (Miss), The Lynches, Shalford, Surrey-364

Higgins, R. E., 2I, Camden-road, N.W.-I000

Higham, B. A. (Miss), Stratton House, Burn-ash-rd., Lee, Kent-1 523 Hildesheim, H. G. (Miss), I3, Redington-road, Frognal, Hampstead $-1777$

Hill, J. S., IA, Steele's Siudios, Haverstock-hill, N.W.-595, I03I

Hill, R. H., 30, Heath-crescent, Halifax-1056

Hillingford, R., I6, Bolsover-street, IV. -584 , I009

Hind, E. M. (Miss), 25, Dartmouth-park-hill, N. W. -I 3 I9

Hindley, G. C., I, Bath-road, Bedford-park, Chiswick, W. -560

Hirst, N., The Mornings, Mudeford, Christchurch, Hants-1669, 1675

Hobkirk, S., Piazza Studios, St. Ives, Cornwall-2SS, 477, 7\$2

Hobley, E. G., Bruaswick-square, Penrith, Cumberland-267

Hobson, C. J., I8, Dancer-road, Fulham, S. W.-I 508

Hodge, A. H., 7, St. Paul's Studios, Telgarth-rd., Kensington, W.-1933

Holgate, T. IV., 2, Clifton-hill Studios, N. IV.-I6I3 
Hollams, F. M. (Miss), Dene-park, Tonbridge-6I2 Holland, A. (Mrs. Sachs), 2, Rossetti Stuảios, Chelsea-639 Holmes, G. A., 62, Cheyne-walk, Chelsea, S.W.-885, 1086 Holst, L., 5 4, Clareville-grore, South Kensington, S. W. -548 Holyoake, R., 5, Primrose-hill Studios, Fitzroy-road, N.W.-32, 67I, $846,88 I$

Home, G., Cromwell Lodge, $E_{p}$ ミom-I $\leqslant 37$

Hook, B., Beefolds, Farnham-475, 922

Hope-Pinker, H. R., 22, Avonmore-road, Kensington, WT.-I924

Hornblower, G., 2, Deronshire-terrace, Portland-place-I $72 \mathrm{~S}$

Horsfall, J., Todmorden, Yorks-I 706

Horsley, G. C., 2, Gray's-inn-square, W.C.-I856, I86o

Horsley, W. C., I, High-row, Kensington, W.-963, 984

Hoskin, R., 2, Sherwell-arcade, Plymouth-I202, I26I

Howard, B. (Miss), 38, Lincoln's-inn-fields, W.C.-I449

Howell, A. M. (Miss), 5, Enys-road, Eastbourne-1428, I498

Horwitz, H., Io, Pembroke Studios, Pembroke-gardens, Kensington252

Hudson, H. J., Alexander Studio, Alfred-place, S. Kensington-I63 Hughes, G., Canning Studios, 2, South John-street, Liverpool--I294 Hughes, J., 28, Lennox-street, Dublin-I92I

Hughes, T., 8, Gloucester Mansions, Harrington-gardens, S. W.-204, $971,972,973,974$

Hughes, W., I I, Belgrave-place, Marine-parade, Brighton-Io8, 677

Hume, R., Sunny Bank, Bury, near Pulborough, Sussex-II 37

Hunn, T. H., New Down-road, Guildford-I234, I303, I324, I337

Hunt, A. A., Studio, 8, Berners-street, W.-7 II

Hunt, E. A., 25, Neville-street, Onslow-gardens, W.-298

Hunter, J. Y., c/o C. Hunter, A.R.A., I4, Melbury-road, Kensington, WW. $-320,635$

Hunter, M. Y. (Mrs.), c/o C. Hunter, A.R.A., I4, Melbury-road, Kensington, WW. $-506,84 \mathrm{I}$

Hurt, L. B., Ironbrook, Darley Dale, Matlock-989

Hutchinson, R. G., 4, Melville-place, Edinburgh-621, 710

I'Anson, C., I2, Primrose-hill Studios, Fitzroy-road, N. II.-I26

Ibberson, H. G., 28, Martin's-lane, E. C.-I094

Inglis, J. J., Montrose, Donnybrook, Dublin-454, 1065, I07 I

Ingram, H. C., 9, Ironmonger-lane, E.C.-I 7 I 2

Ingram, W. A., c/o G. P. J. Hood, Esq., 26, Tite-street, Chelsea S.W. -543 , IOI 4 
JACKSON, T. G., R.A., I4, Buckingham-street, Strand, W.C. -1690 JOHN, W. G., $A$., 2, Woronzow Studios, St. John's-wood, N.W.2015,2055

Jack, R., 27, Claireville-grove Studios, South Kensington-140, 339

Jackson, F. W., The Studio, Middleton, Manchester-II87

Jacomb-Hood, G. F., 26, Tite-street, Chelsea-464

Jaggard, W. R., Heathcote, 3, Grimwood-road, Twickenham-1758

Jagger, W., 39, Monthermer-road, Roath-park, Cardiff-103

James, C. B., 552, Oxford-street, W. -845

James, L. G. (The Hon. Mrs. W. J.), I, Courtfield-rd., S.W.-4So, 577,578

James, R. S., 39, Kildoran-road, Acre-lane, Brixton, S. W. -964

James, W. J.' (The Hon.), I, Courtfield-road, S.W. $-449,1078$

Jannoch, V. (Miss), Dursingham, King's Lynn, Norfolk-I02S

Jarman, H. T., 66, Park-grove-road, Leytonstone-I298

Jay, W. S., Lee House, Littlehampton-4I

Jelley, J. V., Hampton-in-Arden, Warwickshire-303, 721, 892

Jenkins, B. (Miss), 26, New Carendish-street, W.-5I9

Jenkins, F. L., I8IA, King's-road, Chelsea-I918

Johnson, B. V., 20, Victoria-street, S. W.-190I

Johnson, C. E.,Carrington Lodge, 33, Sheen-rd., Richmond,S. W.-1069

Johnson, E. B., 2I, Baker-street, Portman-square, W.-I624

Johnson, P. T. (Mrs.), Adlebury Hall, Nuneaton-II28, I 157

Johnstone, H. J., Wadhurst, Sussex -1326

Jolley, G., 30, Great Russell-street, W.C. -436

Jones, A. G., 483, King's-road, Chelsea-1585

Jones, M. R., I 5, Parkcliffe Mount, Undercliffe, Bradford-445

Jones, W. C., 32, Bedford-row, W.C. $-18_{35}, 1836$

Joy, G. W., The Red Lodge, 5I, Palace-court, Paddington, W.-403

Joyce, A. G. (Miss), Burleigh, Tenbury, Worcestershire-96s

Jupp, G. H., Fern Villa, Cox-green, Maidenhead, Berks-2SI

Kay, A., II, Berkeley-terraces, Glasgow-379

Keeling, W., 375, Glossop-road, Sheffield-775

Keen, A., 4, Raymond-buildings, Gray's-inn, W.C. - I745, I $8 \$ 6$

Keith, L. M. (Miss), 28, Argyll-road, Campden-hill, W.-7I9

Keller, E. R. (Mrs.), Rathcoole, Walton-on-Thames-r 375, 1376

I377, I378, I379

Kelly, R. T., 24, The Temple, Dale-street, Liverpool-II94

Kemp-Welch, L. E. (Miss), Kingsley, Bushey, Herts-427

Kemp-Welch, E. (Miss), Kingsley, Bushey, Herts-1 506

Kendall, T. H., Warwick-1999

Kennington, T. B., 8, Victoria-grove, Chelsea -589 
Kerr, C., I8, Aubrey-walk, Campden-hill, N.W.-99, 996

Kilburne, G., I, Fitzroy-road, Regent's-park -854, 934

Kilburne, G. G., 39, Steele's-road, Haverstock-hill-840

Kindon, M. E. (Míss), St. George, Chalk-hill, IVatford, Herts-1050

King, B. (Miss), Clyde Villa, Shoreham, Kent- 525

Kins, F. C., 24, Great Titchfield-street, Oxford-street, W. -969

King, G., Harting, Petersfield, Hants-388

King, H., I03, Finchley-road, N.W.-48, 737

King, Y., I03, Finchley-road, N. $-527,550$

Kingsford, F. (Miss), 5, Stratford S udios, Stratford-rd., W.-I313, 1623

Kinsley, A., 2, Corinne-road, Tunnell-park, N. -435 , I I 86

Kirchmayr, C., 29, The Avenue, Bedford-park, W. -452

Kirkpatrick, J., 4I, Castle-street, Liverpool-1237

Kneen, W., Maclise Mansions, Addison-road-station, W.-67

Knight, Adam, 73, Henry-road, Bridgford, Nottingham -500

Knight, A., I, Woronzow-road Studios, St. John's-wood, N.W.-

1205,1229

Knight, A. (Miss), I, Belgrave-road, Gloucester-I509

Knight, A. W., c/o S. Jennings, I 5, Duke-street, Manchester-square, IV.-1 322

Knight, H., 8, Belgrave-square, Nottingham-66, Іо6, I092

Knowles, G. S., 5, Parkhill-road Studios, N.IW.-28, I 57

Kortright, H. S., 203, South Lambeth-road, S. W.-1630

Kotéra, J., Rudolfovo Nabrezi 6, Prague, Bohemia-I861, I862, I867, I873

Kricheldorf, C., Staftord House, Tetbury, Gloucester-700

LEADER, B. W., R.A., Burrows Cross, Gomshall, Guildford-r75, 249, 376,839

LESLIE, G. D., R.A., Riverside, Wallingford, Berks-168

LUCAS, S., R.A., New-place, Woodchurch-road, West Hampstead, N.IV. $-37,62,1639,1641$

LA THANGUE, H. H., $A$., Graffham, Petworth, Sussex-68, 199, $35 \mathrm{I}, 569$

Lacy, G. J. J., I20, Caledonian-road, N.-I80I

Lamond, W. B., 6r, Reform-street, Dundee -715

Lancaster, A. D., 9, Upper Phillimore-gardens, Kensington-5I 7

Lanchester, M. (Miss), Ripley Villa, New Malden, Surrey-553

Langdon, E. A. (Miss), Glenalmond, The Park, Nottingham-I Igo

Langley, W., Westbourne, Alexandra-road, Penzance-I 72, 749

Lansdown, G. A., 9, Regent-street, Waterloo-place, S.W.-1693

Lantéri, E., Oakley Studio, I Upper Cheyne-row, Chelsea-r979 
Laurent, C. S., c/o C. Roberson \& Co., 99, Long-acre, W.C.-I105, 1106 Lavender, W. R., I28, Manchester-road, Southport-602

Lavers, A. C., I4, Heathfield-gardens, Chiswick-1 792, 1793, 1906

Lawrence, M., I, St. Leonard's Studios, Chelsea-I 997

Lawson, A., 4, Dudley-street, Wolverhampton-I9I

Lee, J., Middleton-on-Teesdale, Darlington- 532

Lee, J. S., 28, Theobalds-road, W.C.-I803

Lee, S., 6, The Studios, Holland-park-road, W.-230

Lees, I. (Miss), The Larches, Pembury, Kent-I584

Lehmann, R., 28, A bercorn-place, N.W. -395

Leigh, G. L., Hampton-in-Arden, Warwick-I88

Leighton, E. B., 7, Priory-road, Bedford-park, W.-6o6

Lemon, A., Brockham, Betchworth, Surrey-970

Lendrum, F. (Miss), Sunny Bank, Edgerton, Huddersfield-I496

Lenfestey, G. H., 7, Holland-park-road, Kensington, W.-II96

Leslie, P., Riverside, Wallingford, Berks-1270, I 325 , I6 59

Levick, R. (Miss), Leighton Lodge Studio, Edwardes-square, Kensington, W.-1943, 1968, 1986, 2038

Lewis, A. N., The Cottage, Granada-road, Southsea-594

Lewis, G. R. (Miss), 46, Brixton-hill, S.W.-I475, I5IO, I 5 I I, I 514

Lewis, M. (Miss), I I I, Goldhurst-terrace, S. Hampstead, N.W.-I504,

1513

Lindner, G. (AIrs.), The Warren House, St. Ives, Cornwall-306

Lingwood, E. T., The Ferns, Dunwich, Saxmundham-187, 192

Lintott, H. C., 57, Boston-road, West Croydon-I453

Lion, F. M. (Miss), 4, Arkwright-road, Hampstead -722

Little, E., 9, Stanley Studios, Park-walk, Chelsea-78I

Little, G. L., Wraycott, Kingswood, Reigate-I044

Lodge, G. E., 5. Verulam-buildings, Gray's-inn, W.C. -596

Logsdail, W., 3539, Madonna dell' Orto, Venice-76, 83I

Lomax, J. A., I 7, Marlborough-rd., St. John's-wood, N.W.-\$60, S7 3 Loosely, G. F., Studio, 37, Cheyne-walk, S.W. -78

Loudan, M., 48, Circus-road, N.W.-322, 1087

Low, C., Bridge-street, Hungerford, Berks-1249

Lowe, A., 28, Massey-street, Nottingham-457

Lucas, E. E. (Miss), Io, Marlborough-hill, N.W.-346

Lucas, M. (Mrs. J. S.), New-place, Woodchurch-road, West Hampstead $-264,444,505$

Lucas, T. G., Hitchin, Herts-I 783

Lucchesi, A. C., 2, Camden Studios, Camden-street, N. W.-195S, 1964 Ludlow, H., Plas-Newydd, Hanwell, W.-690, Si3, Si 5 Luker, A. (Mrs.), 22, Campden-hill-square, W.-726, 735, 12SS 
Luker, G. L., Io, New-inn, W.C.-I262

Lumley, E. (Miss), I, Marlborough-place, St. John's-wood, N.W.-240 Lund, N. M., 6, Stratford Studios, Stratford-rd., Kensington, W.-I4 Lungren, F., 5, Edwardes-square Studios, Kensington, W.-239, 555 Lutyens, C., I6, Onslow-square, S.W.-629

MACWHIRTER, J., R.A., I, Abbey-road, N.W.-20, I44, 308, 314 MACDETH, R. W., A., 28, Tite-street, Chelsea, S. W.-755, I55I MORRIS, P. R., A., 92, Clifton-hill, N.W.-100, 66I MURRAY, D., A., I, Langham-chambers, Portland-place, W.-54, I $39,486,55^{8}$

Macarthur, L. G., Willersey Broadway, Worcestershire-I $5 \mathrm{I}$ Macartney, M., 52A, Berkeley-sq., W.-I790, I797, I798, I802, I833 Macbeth-Raeburn, H., 53, Marloes-road, Kensington-805 McClatchie, F. (Miss), 28, Edith-road, West Kensington-1373 McClure, J. C., I2, Jubilee-place, King's-road, Chelsea-I948, 2003, 2005,2011

McCormick, A. D., 58, Queen's-road, St. John's-wood, N.W.-930 McDonald, M. M. (Miss), 30, Ledbury-road, Bayswater-I 494 McDougal, J., Min-y-don, Cemaes, near Amlwch, Anglesey-IIO4 Macdougall, N. M., 2I I, West Campbell-street, Glasgow-9, 948 MacGeorge, W. S., II, Melville-place, Edinburgh-888 Macgregor, J. (Miss), I2, Chalcot-gardens, South Hampstead-I059 McGregor, R., 36, Hanover-street, Edinburgh-55 I, I059

Macintosh, J. M., Woolhampton, near Reading-913

Mackie, C. H., Colbridge Studio, Murrayfield, Edinburgh-47 I Macklin, T. E., 22, Blackett-street, Newcastle-on-Tyne-762 McLaren, C. G. (Miss), I76, Bath-street, Glasgow-I409, I4IO, I4II McLean, W. J., I, Oakley Cottage Studios, Upper Cheyne-row, S.W. $-1965$

Maclear, A., I90 Foster-hill-road, Bedford-I443

MacRory, A. A. (Miss), 88, Via delle Ruote, Florence, Italy-616 Maddison, J., 149, Grange-road-east, Middlesboro-847

Maddox, R. W., 22, King Henry's-road, N.W.-33I

Maitland, A. F. (Capt.), Naval and Military Club, W. -826

Maitland, G. L. (Viscountess), I4, Lower Sloane-street, S.W.-I404 Mallows and Grocock (Messrs.), Times-buildings, Bedford-1764 Mann, H., 78, Lexham-gardens, Kensington, W. $-494,546$ Manning, W. W., 55A, Bedford-gardens, Kensington, W.-355, 386 Mansell, M. (Miss), 5, Fernshaw-road, Fulham-road, S.W.-162 Margetson, W. H., Io7, Thornlaw-road, West Norwood, S.E.-22I Marks, A. (Miss), Io, Matheson-road, West Kensingt ${ }^{n}$, W.-I653 
Marks, G., Shere, Guildford, Surrey-1124, I 210 , 1222, 1321, 1335, I341, 1345

Marks, M. (Mrs. H. S.), 25, Goldhurst-terrace, N. W.-I 346

Marrable, A. (Mrs.), 6o, Cleveland-square, Hyde-park, W.-I 149

Marshall, C. E., 49, St. James's-street, Piccadilly-I633, I644

Marshall, J. Fitz, The Studio, High-street, Epsom-7I4

Marshall, W. (Miss), Red Brick House, Campden-hill-road, W.-1481,

1493

Marson, T. E., Crick, Rugby-491

Mart, F. G., 22, Carleton-road, Tufnell-park, W.-123I

Martin, A. C., 5, Great College-street, Westminster-1880

Martin, E. (Miss), Woodhall, Sevenoaks-24I

Martin, G. D., 3, Pall-mall-east, S. W.-I 726

Martineau, C. (Mrs.), 3, Eldon-road, Hampstead-I 577

Martineau, L. (Miss), 4, South-road, Clapham-park, S.W.-507

Maryon, E. (Miss), Oakwood, South Hanningfield, Essex-2032

Mason, E. (Mrs.), Homestead, Tilford, Farnham, Surrey--1433

Mason, F., Rockside House, Blenhein-terrace, Scarborough-I 132

Massey, G. (Mrs.), 6, Albion-rd., South Hampstead-1406, I407, 1408

Matear, H. A., The Temple, Dale-street, Liverpool-I855

Mathews, L. B. (Mrs.), 133, Green Lanes, N.-640

Mawson, T. H., Windermere-1734, I 736, I 737, I 852

May, A., 26, Medhurst-road, Bow, E. -576

May, A. D., 9, St. Paul's Studios, West Kensington-119, 574

May, E. J., 21, Hart-street, Bloomsbury-square, W.C.-1809

Mayor, F., c/o A. Toft, Esq., II, Trafalgar Studios, Manresa-road,

Chelsea-I IOI, I I 79, I289

Meade, A., St. Ives, Cornwall-21 5, 374

Measom, W. F., 2, Stanley Studios, Park-walk, Chelsea-I3I5

Mee and Jennison (Messrs.), 32, Victoria-street, Manchester-1697, I 723, I $773,1894,1904$

Meihé, W. A. (Miss), Limatburg, Ambleside-avenue, Streatham, S. W. $-\mathrm{I} 45^{8}$

Menpes, M., 25, Cadogan-gardens, Chelsea-1550

Menzies, W. A., I2, Holtham-road, Abbey-road, N. W.-774, I 333

Merbitz, M. P. de (Mde.), I I, Rue de Penthièvre, Paris-I469, I4S4

Mercer, F., Abbots Bromley, Rugeley-12I4

Merrylees, A. R. (Mrs.), 26, Bassett-road, Ladbroke-grove, W.-I405,

1416

Metcalfe, G., 95, Cheyne-walk, Chelsea-703

Meteyard, S. H., Parkstone, Moseley, Birmingham-III 5

Meyer, J. (Miss), 3, Freeland-road, Ealing, IV. -769 , 918 
Meyerheim, R., Lindeneck, Wimblehurst-road, Horsham, Sussex-I I Michael, F. H., 34, Romola-road, Herne-hill, S.E. -85 I, I265

Michie, J. C., 9, Primrose-hill-studios, Fitzroy-road, N.W.-326, 50 Milbanke, M., 7, Trafalgar-studios, Manresa-road, Chelsea-Io64

Mileham, C. H. M., I, Lincoln's-inn-fields, W.C.-I8I 2

Mileham, H. R., Copers Cope, Beckenham, Kent-789

Mileham, M. L. (Miss), Hill-crest, Westhill, Sydenham-I488

Miller, J. D., I59, High-street, Hadley, Barnet-I 528

Miller, W. E., 3, St. Petersburg-place, Bayswater-423

Millet, F. D., Broadway, Worcestershire-29, 1058

Mills, A. J., 23, Jeffreys-road, Camden-town, N.W.-200I

Mills, E. (Mrs.), 21, St. Mary-Abbott's-terrace, W.-1358

Milnes, W. H., 56, Croftdown-rd., Highgate-road, N. W.-I 552, I 558,

I 560

Minty, J. A., Io, Gray's-inn-square, W.C.-I848

Mitchell, A., 39, Great Marlborough-street, W.-1763, 1868

Moberly M. J. (Mrs.), Ravenstury-gardens, Mitcham-8

Molyneux, E., Rathleigh-gate, West-end-lane, West Hampstead, N.W.

$-547$

Monk, W., 86, Fellows road, South Hampstead, N.W.-I677

Montalba, H. (Miss), Sog, Campo S. Agnese, Venice- 524

Montford, H., 8, Winders-road, Battersea, S.W.-2052

Montford, P. R., 8, Winders-road, Battersea, S.W.-I9I9, I945, 2030

Moore, A. H., Raglan-cottage, Whipp's-cross, Walthamstow-748,

I 223

Moore, E. M. (Miss), 4, Bath road, Bedford-park, Chiswick-I93I

Moore J. (Miss), The Studio, I 53, Tachbrook-street, Westminster,

S. W. -869

Moore, S., I6, Parchmore-road, Thornton-heath-46

Moore, T., 37, Old Queen-street, Westminster, S. W-I I IO, I 778

Morgan, A., 89, Albert-bdge.-rd., Battersea-park-106, 1 52, 833, 849

Morgan, E. M. (Miss), 89, Albert-bridge-road, Battersea-park-I 567

Morgan, F., I 55, Auckland-road, Upper Norwood, S.E. -674

Morgan, O. (Miss), 7, Roland-gardens, S. W.-I 479

Morgan, IV. J., I 7, Radnor-road, Handsworth, Birmingham-I I80

Morley, I. (Miss), 5, Lyndhurst-road, Hampstead, N. WV.-348

Morris, L. M. (Miss), 25, Ifield-road, Fulham, S.W.-I971, 1994

Morris, W. B., 37, Warwick-road, South Kensington, S.W.-r287

Morrison, K. M., 55, Glebe-place, Chelsea, S. W.-272, 64I

Morrison, R. E., 29, Liverpool and London Chambers, Liverpool-94

Morrow, A., I, Albert Studios, Ba tersea-park, S. W.-1093 
Mortlock, E. (Miss), I22, Sloane-street, S.W.-80

Mostyn, T., Studis, Chorlton-cum-Hardy, Lancashire-176, 214

Mottra:n, C. S., 57, Fordwych-road, We it Hampstead, N.W.-1192,

1215

Mountford, E. W., and G. Lucas, I7, Buckingham-street, StrandI 891, I 892

Muckley, IV. J., The Hall, White Notley, Witham, Essex-I I44

Mulock, F. C., 28, Walton-street, S. W.-IOI3

Munnings, A. J., Mendlam, Harleston, Norfolk-391, 9j2

Murray, A. A. H., 49, Montague-square, IV.-1348, I 354

Murray, C. O., 4I, The Grove, Hammersmith-1576

Murray, G., 5, Scarsdale Studios, Stratford-road, Kensington, W.1043, I I98, I6I8, I9I2

Muschamp, S., I65, Goldhurst-terrace, South Hampstead, N. W.-I030 Musgrave, H., I6, Rosemont-road, Acton, IV.-1 78

Musto, F., Greek-street Chambers, Park-row, Leeds-I879

Myers, H. (Miss), 3, Garden-road, Abbey-road, N.IV.-373, I425, 1426,1427

NORTH, J. W., A., Washford, Taunton-97

Nathan, E. (Mrs.), 37, Barkston-gardens, S. WT.-I 527

Naylor, M. J. (Miss), Stamford-bdge. Studios, Fulham-rd., S.IV.-ror2

Nelson, H. E. H., I Io, Grantham-road, Clapham, S.IV.-I6 7

Netherwood, A., Tywyn, near Llandudno-622

Nettleship, J. T., 58, Wigmore-street, W. -254

Neve, IV. IV., 5, Bloomsbury-square, W.C.-I899

Newbery, F. H., The School of Art, Glasgow-75I

Newberry, J. E., 47, Victoria-street, S. IV.-I 750

Newbolt, F., Oakley Lodge, Weybridge-I 540

Newman, A. C. (Mrs.), 2, Woburn-square, IV.C.-I46r

Newton, E., 4, Raymond's-buildings, IV.C.-I688

Newton, P. E., 2, New-square, Lincoln's-inn, IV.C.-I 754

Nichol, E., Snape, Saxmundham-1083

Nicholson, C. A., 2, New-square, Lincoln's-inn, W.C.-1730, I733,

I 743, I 749, I 755, I 796

Nicol, E. E., The Dell, Feltham, Middlesex-i is

Nicol, J. W., Park Cottage, Pelham-street, S. Kensington, S. IV.-2S6 Niven and Wigglesworth (Messrs.), 34, Mecklenburgh-square, IV.C.1725,1845

Noble, R., East Linton, Prestonkirk, Addingtonshire, N.B. -300 Noel, J. B., 33, Chantry-road, Moseley-33

Norman, P., 45, Evelyn-gardens, S. IV.-1305, I340 
Normand, E., Aucklands, Upper Norwood, S.E.-1006

Nowell, A. T., 92, Fellows-road, South Hampstead, N.W.-I I 7, 985

Nowlam, C. (Miss), The Elms, North Cheam, Surrey-I 5 I 7

Noyes, D. (Miss), The Old House, Mitston, Salisbury-360

Nye, H., Bury-common, Pulborough, Sussex-I I Io

Nye, M. (Miss), I6, Colville-terrace, Kensington-park, W.-I459

ORCHARDSON, W. Q., R.A., I3, Portland-place, W.-I43

OULESS, W. W., R.A., I2, Bryanston-square, W.-8I, I74, I89, 377,559

Offord, G. E. (Miss), 46, St. Giles-street, Norwich-I I83

Offord, M. H. (Miss), 6, Oval-rd., Gloucester-gate, Regent's-park-701 Ogden, J., 6, St. Dunstan's-terrace, Canterbury-I779

Oldacre, R. S., I4, Temple-street, Birmingham-I 709

Olivier, H. A., 2S, Finchley-road, N.W.-424, 579, 670, I0331

Olsson, J., St. Ives, Cornwall-38I

Orchardson, C. M. Q., 54, Parkhill-road, Haverstock-hill, N.W.946, 1004

Orr, A. A., Ormiston, Harrow-view, Wealdstone, Middlesex-I759

Osborne, W., 5, Castlewood-avenue, Rathmines, Dublin-248, 284, 492

POYNTER, Sir E. J., P.R.A., 28, Albert-gate, S.W.-I60, 224, I 139

PRINSEP, V. C., R.A., I, Holland-park-rd., Kensington, W.-I48

PARSONS, A., A., 54, Bedford-gdns., Kensington, W. -43, 86, I 109 Padday, C. M., Bosham, Sussex-580, 1037

Palethorpe, M. C. (Miss), 9, Colquitt Chambers, Colquitt-street, Liverpool-967

Palmer, E. A. (Mrs.), Giltar, Watford, Herts-I454

Palmer, S., Io, Newton-grove, Bedford-park, W.-IIO7, I332

Parker, J., 5, Melina-place, Grove-end-road, N.W.-I I 26

Parkinson, F. (Mrs.) Deerhurst, Streatham, S. W.-I95I

Parlby, G., 374, Goldhawk-road, W.-I739, I 746

Parry, C. J., Addison House, Whitney-road, Leyton, Essex-777

Parsons, A. W., 75, Hampton-park, Redland, Bristol-i I 76

Parsons, J. V. R., 27, Liverpool and London Chambers Exchange, Liverpool-440

Parton, E., 3, Brunswick-square, W.C. $-83,504$

Paterson, W., 6r, Chancery-lane, W.C.-I

Paton, H., Ardendam, Marple-I62I

Patry, E., I4A, Kensington-crescent, Kensington, W.-336 .

Pattinson, A. (Miss), 49, Buckland-crescent, Hampstead, N.W.-I472 
Pattison, E. (Mrs.), Billesdon, Leicester-I 387

Paul, R. W., 3, Arundel-street, Strand, W.C.-1839, 1847

Pawley, C. J. C., 25, Victoria-street, Westminster-I 784

Peacock, R., I I, Holland-park-rd., Kensington, W.-19, 296, 467, 564

Pearse, A., Elmleigh, Hampstead-heath-1593

Pedder, J., Eastfield, Furze Platt, Maidenhead-746, I I I4

Pegram, H.A., 36, Marlborough-hill, N.W.-I985, 204I, 2056

Penrose, J. D., 44, Finchley-road, N. IV. -53, 993

Percy, H. S., 29, Avenue-road, Shepherd's-bush, W. -882

Perkin, J.C., 5, Union-court, E.C.-I683

Perugini, C. E., 38A, Victoria-road, Kensington, W. $-9 \mathrm{r}$

Perugini, K. (Mrs. C. E.), 38A Victoria-road, Kensington, W.-I84

Petrie, G., 49, Roland-gardens, South Kensington-432

Pettafor, C., Elsie-bank, Eltham-998

Phillpotts, M. S. (Miss), School-house, Bedford-I5I8

Pibworth, C. I., 4, Bramerton-street, Chelsea, S. W.-1950, 1954,

1998

Pickering, J. L., 8, Ormond-terrace, Regent's-park, N. W.-6o

Pilkington, M. E. (Miss), 45, York-mansions, Battersea-park, S.W.-

I4I 2

Pite, B., 48, Harley-street, W. $-\mathbf{I} 832$

Pitman, J. R. A. (Miss), Basford Vicarage, Notts -523

Pocock, L. L., 28, Blomfield-road, Maida-vale-228, I2 6

Pomeroy, F. W., I, Wentworth Studios, Manresa-road, Chelsea-r929, 2054

Pontin, G., Church House, Yapton, Arundel- -489

Porter, E. P., I3, Alexandra-road, Norwood, S.E. -479

Porter, F., Wribben Hall, Bewdley-I247

Postlethwaite, M. E. (Miss), 4I, Oxford-road, Kilburn, N. W.-43I

Pott, C. M. (Miss), 8I, Cornwall-gardens, S. W.-I554, I 563

Potter, W. B., 2, Bolton-gardens, S. W. -93

Power, C. E., 28, Great Ormonde-street, W.C.-I 74I

Power, H. H., Farrants, Dunsford, near Exeter, Devon-470

Pownall, L. A., 4, Acacia-road, St. John's-wood-121 7

Pownall, M. (Miss), 53B, Via Margutta, Rome-1923

Poynter, A. M., I 48 A, Slo nne-street, S. W.-I885

Praetorius, C. J., Pomona Studios, New King's-ro dd, S. W.-I I 8I

Praga, A., The Grey House, Hornton-street, Kensington-I37 I

Pratt, J., Royal Society of Artists, Birmingham-4r2, 92 r

Pratt, J. B., Carlton House, Harpenden, Herts. - I67 I

Prentice, A. N., Hastings House, Norfolk-street, IV.C.-I 700, 1719

Priestman, A., 3, Walmer Villas, Bradford -522 : 
Priestman, B., 29, Beaufort-street, S. IV. -332

Prior, E. S., Io, Melina-place, N. W.-I689

Probst, C., 23 IV. B. Theresianumgasse, Vienna-30I

Proctor, A. E., Heathend, Albury, near Guildford $-385,870$

Pryce, T. E., IO, Gray's-inn-square, IV.C. - I 902

Pughe, B. A. (Miss), Cotterell House, Towyn, North Wales-73

Pyke-Nott, I. (Miss), Porlock, Somerset-I I 56, 1507

Quennell, C. H. B., I 7, Victoria-street, Westminster, S. W.-I900 Quicke, E. P. (Miss), The Lynches, Shalford, Guildford, Surrey409

Quinton, A. R., Io, New-court, Carey-street, W'.C.-I I 55, I I 73

RICHMOND, Sir W. B., K.C.B., R.A., Beavor Lodge, Hammersmith $-138,585,662,1591,1605,1615,1642$.

RIVIERE, B., R.A., 82, Finchley-road, N.W.-69, 219

Rae, H. (Mrs. E. Normand), Aucklands, Upper Norwood, S.E.-I075 Raine, H., 21, Oakley-street, Chelsea-1831, I905

Ram, J. A. (Miss), Eccleston Studios, 49, Hugh-street, Eccleston-sq., S. IV. -660

Ransom, G., Fairfield, Farnham, Sussex-428, 734

Ransome, J., II, Argyle-place, Regent-street, W.-I 71 5

Ravenhill, M. F. (Miss), 3, Cleveland-gardens, Ealing, W.-I224

Rea, C., 53, Beaufort-street, Chelsea-73I

Reckitt, F. W., 2, West Hampstead Studios, Sherriff-road, West Hampstead, N.W. - I 59

Redgate, A. W., I I, Charmwood-grove, W. Bridgford, Nottingham848,1007

Reid, F. M. (Miss), 62, Parkhill-rd., Hampstead, N.W.-804, 8I4, 935 Reid, J. R., 62, Parkhill-road, Hampstead, N.W. -503

Reid, S., I25, Handley-road, Crouch-hill, N.-93 I

Reid, S., Woodridings, Pinner, Middlesex-I 56

Renault, Lex de, I, Lyncroft Mansions, Fortune-green-road, Hampstead, N.IV. $-456,473$

Reynolds-Stephens, W., Io, Hill-road, N.W.-2023

Rheam, H. M., Newlyn, Penzance-I I I 7

Richards, A. (Miss), 25, Rossetti Mansions, Cheyne-walk, S. W.-I2S Richards, IV. T., 2 I, Pembridge-road, Notting-hill, W.-36, 260 Richardson, C. E., Kirklevington Hall Farm, York-468, 94I Richardson, E. (Miss), c/o Mr. Smith, Coldharbour, nr. Dorking-46o Richardson, F. S., Sandy, Bedfordshire-1032, го6I Richardson, H. L., 83, Ondine-road, East Dulwich, S.E.-I 586 
Richardson, J. T., Etaples, Pas de Calais, France-76I Richardson, R. J., c/o E. Lander, 22, Joubert Mansions, Jubilee-place, King's-road, Chelsea-I 647

Ricketts, W. C., 20, Bank-street, Barbourne, Worcester-I330

Rigby, H. M. (Miss), Abbott Hayes, Chester-1982, 2043

Rigg, E. H., 280, Swan-arcade, Bradford, Yorkshire-1022

Rivers, L., 2, Darenth-road, Stamford-hill, N.-1067, 1147

Riviere, H. G., 38, Abercorn-place, N.W. - 568, 962, 1054

Robb, W. G., I93A, Gray's-inn-road, W.C.-292

Roberts, E., 6, William-street, Lowndes-square-I I 45, I I64

Roberts, K. M. (Miss), I69, Grove-street, Liverpool-447

Robertson, G. E., I90, Ebury-street, Eaton-square, S.W.-375

Robertson, H. R., I, Steele's Studios, Haverstock-hill, N.Wl.-I273, 1282

Robertson, J. K. (Mrs.), The Guest House, Wanstead-I446

Robertson, P., Meadow House, Godalming, Surrey-1299

Robertson, T., Studios, 21, Camden-road, N.W. -443

Robertson, V. J., I90, Ebury-street, Eaton-square, S.W.-366

Robinson, M. (Miss), St. Hilda's, Hampton Wick-2.487

Robinson, T., Glenhurst, Granville-road, Stroud-green, N.-163I

Robinson, W., 66, Montholme-road, Wandsworth-common, S.W.-

876,902

Roe, F., I04, Priory-road, West Hampstead-23, IoIo

Rogers, M., jun., c/o Messrs. Trollope, 77, Grosvenor-road, S. W.-I920 Rollins, J. W., 72, Cheyne-walk, Chelsea-1983

Ronner, H. (Madame), 57, Chaussée de Vleurgat, Brussels- 889 Rooke, H. K., Trenoweth, Egmont-road, Sutton, Surrey-II4S Rope, G. T., Blaxhall, Wickham Market -976

Rose, H. R., 50, Harrington-gardens, South Kensington, S.W.-246 Ross, J. (Mrs.), 20, Loudoun-road, St. John's-wood, N. W. $-47 \mathrm{~S}$ Rossi, A. M., 27, Maitland-park-villas, Haverstock-hill-I I77, I 197 Rouse, N. (Miss), Clarence-house, Teignmouth, Devon-I450 Rowe, W., jun., 6, Lavender-gardens, Battersea, S.W.-765

Rudd, A. J. (Miss), Teesdale, Spencer-road, Bournemouth-1203 Russell, Mallows, and Grocock, II, Gray's-inn-square, W.C.-I\$46 Ryland, H., 4, Pembroke Studios, Kensington, W.-I IS5, I33I

SANT, J., R.A., 43, Lancaster-gate, Hyde-park, W., Principal Painter in Ordinary to Her Majesty-II 5, 233, 856, 9 I I

SARGENT, J. S., R.A., 33, Tite-street, Chelsea, S.W.-44, I90, 213, 625, 630, 729

SHAW, K. N., R.A., 6, Ellerdale-road, Hampstead, N.W.-1748 
STONE, M., $\boldsymbol{R} A$., 8, Melbury-road, Kensington, W.-16I SHANNON, J. J., A., 3, Holland-park-road, Kensington, W.-50, 121, $37 \mathrm{I}$

SMYTHE, L. P., A., Château Honvault, Pas Wimille, Pas de Calais- 55

SOLOMON, S. J., A., 6o, Finchley-road, N.W.-255, 539, 597, 1024 STOREY, G. A., $A, 39$, Broadhurst-gardens, South Hampstead, N.W.-107, 526, 838, 108r

SWAN, J. M., A., 3, Acacia-road, N.W.-1038, 2014, 2019 Sachs, J. W. (Mrs.), 32, Whitehead's-grove, Chelsea-1456 Sadler, W. D., Hemingford Grey, St. Ives, Hunts. - 285, 327 Sainsbury, G. E. (Miss), 4, Emanuel-avenue, Acton, W. -798 Salisbury, F. O., 4, Limerston Studio, West Brompton, S.W.-466 Salmon, J. C., Elsinor, Deganwy, Llandudno-1 166, I 213 Saltmer, F. A. (Miss), Whiteholm, Shoreham, Sussex-64 Sambourne, L., 18, Stafford-terrace, Kensington, W.-1588 Sang, F. J., 68, Carlton-rd., Kentish-town, N.W. $-509,513$, 817, 819 Sansom, N. (Miss), 60, Netherwood-road, West Kensington--II52,

1372,1415

Savidge, J. T., 90, Carter-street, Newington, S.E. -895 Sawyer, E. (Mrs.), Haverstock Cottage, Bushey Heath, Watford-166I Scannell, E. (Miss), 20, Victoria-road, Kensington, W.-195

Schloesser, C., I, Primrose-hill Studios, Fitzroy-road, N.W. -929

Schofield, K., Gate House, Clayton, Bradford-688

Schultz, R. W., I4, Gray's-inn-square, W.C.-1691, 1704

Scott, Ada (Miss), 4, High-street, Ventnor-487

Scott, Amy (Miss), I4, Preston-street, Brighton-1310

Scott, J., 5, The Mall, Parkhill-road, Haverstock-hill, N.W.-5I, 210 Scott, J. O., 35, Spring-gardens, S.W.- 1834

Scott, M. H. B., The Red House, Douglas, Isle of Man-1756, 1804,

I863, 1869, I870

Scott, S. E., 27, Margaretta-terrace, Chelsea, S.W.-707

Scully, H., Studios, II, Nelson-place, Cork-10

Sedcole, H., Chillingly, Knebworth, Herts-1655

Semenowsky, E., 15, Trinity-road, Tulse-hill, S.W.-803, 942

Senior, M., 9, South-parade, Leeds-243, 387, 397

Seth-Smith, W. H., 46, Lincoln's-inn-fields, W.C.-1805

Shackle, G. H., Rosedale, Stanford-road, New Southgate, N.-1826 Shackleton, W., 30, Churchfield Mansions, New King's-road, Fulham $-324,836$

Shand, C. R. (Miss), Studio, Gas Co. Chambers, Newcastle-on-Tyne- 
Sharman and Archer, Wellingborough-1858

Shaw, B., 28, Addison-road, W.-IO34

Shaw, B. (Mrs. E.), 28, Addison-road, Kensington-1451, 1452, 1466

Shaw, J. J., I 50, Camden-road, N.W.-I 842

Shaw, K. (Miss), 26, York-street-chambers, Bryanston-sq.-1960, 1987 Sheard, T. F. M., 3, Turner's Studios, Glebe-pl., Chelsea, S.W.-342 Shelley, F., 39, Torrington-place, Plymouth-1 I29, 1239

Shelley, F., 4, Margravine-gardens, West Kensington, W.-69I

Sheppard, E. (Miss), I, York-road, Northampton-728

Sheppard, O., Castle-rooms, Lenton-road, Nottingham-1980

Shepperson, C. A., I8, Kensington-court-place, IV.-I 589 , I604, I629 Sherborn, C. W., 540 King's-road, Chelsea-1 583

Short, G. H., Avondale, Rosemont-road, Acton, W.-I 575, I638, 1662 Short, R., 22, The Walk, Cardiff-874, 891

Shrigley and Hunt (Messrs.), 28, John-street, Bedford-row, IW.C.-184I Sigmund, B. D., Lyndale, Wrexham-road, Slough, Bucks-1225, I327 Simonds, G., 65, Hamilton-terrace, St. John's-wood-I974

Sims, C., St. Lawrence, Southminster, Essex-402

Simson (Mrs. S.), 37, Rue Boileau, Auteuil, Paris-I390, I524

Slater, J. F., I3, Mosley-street, Newcastle-on-Tyne-420

Sloane, M. A. (Miss), 57, Bedford-gdns., Campden-hill, W.-I 566, I 57 I Small, A. G., 294, Camden-road, N.-4I2

Small, F. (Mrs. D. Hardy), 36, Gloucester-road, Regent's-park, N.W. $-220$

Small, W., 294, Camden-road, N.W.-IoI6

Smith, A. G., 3, The Mall, Parkhill-road, Hampstead, N.W.-109

Smith, A. H., 3, Dancer-road, Fulham-road, S. W.-1895

Smith, C., I5, Rossetti Mansions, Cheyne-walk, Chelsea-6I I

Smith, C. (Miss), The Studio, 58, Rathbone-place, IV.-I 53 I, I545

Smith, C. A., Lashams Hill, Witley, Surrey-I I 72

Smith, C. E. P. (Mrs.), Kitcat Cottage, Greyshot, Haslemere, Surrey

-9 I 7

Smith, H., 7, Bolton Studios, Redcliffe-road, S. W.-I 70 Smith, H. E. (Mrs.), I4, Hemstall-road, West Hampstead-I386 Smith, L. B. (Mrs.), Rylett-crescent, Shepherd's-bush, W.-I370 Smith, M. M., 6A, Berners-street, W.-I\$97

Smith, N., The Studios, Edith-terrace, Chelsea-I230 Smith, R., 54, Pembroke-road, Clifton, Bristol-1246 Smith, R. B. L. (Mrs.), 3I, Portman-square, W.-I304 Smyth, M., 56, Abbey-road, St. John's-wood, N. W. -77 Smythe, M. (Miss), Château d'Honvault, par Wimille, Pas de CalaisI I 50, 1226 
Snowman, I., Studio, 48, Fortune-green-road, West Hampstead485,604

Solon, L. V., Bank House, Vine-street, Stoke-on-Trent-2044

Somerscales, T., 3, Leicester-street, Hull-I042

Somerscales, T., jun., 30I, Beverley-road, Hull, Yorks-13 $3{ }^{2}$

Soord, A. U., I, Meadow Studios, Bushey, Herts-1073, I22 I

Soper, H. C. W., I4, Rectory-grove, Clapham, S.W.-I39I

Spain, J. E., 28, Ovington-street, Chelsea-I 73I

Speed, H., Onslow Studios, 183, King's-rd., Chelsea-380, 1596, 1602

Spence, E., Cushendall, Pit Farm, Guildford-I 122, I 254

Spence, P. F. S., 20, Ruskin Mansion, Queen's-club-gardens, Kensington, W. -48

Spencelayh, C., Trefusis Villas, Windmill-road, New Brompton453

Spencer, F., 32, Geneva-road, Brixton, S. W.- 852

Spenlove-Spenlove, F., Kent House, Lansdowne-road, W.-I45, I77, 644,750

Spooner, C., Eyot Cottage, Chiswick-mall, W.-IgII

Sprague, E. (Miss), Bingham Studios, Bingham-place, Nottinghamstreet, W. -842

Spurling, C. (Miss), 63, Redcliffe-road, South Kensington-I849, I85 I Stamp, W. L. (Miss), 29, High-street, Hampstead, N.W.-I308

Stanley, D. (Lady Stanley), 2, Richmond-terrace, Whitehall- $75^{2}$

Stannard, E. (Miss), Harpur-place, Bedford-1200

Stannard, S., Flitwick, Beds-1097, II 19

Stannus, A. C., 39, Westbourne-park-road, W.- 158

Stanton, E. (Miss), Upfield, Stroud, Glos.-65I

Starling, A., Wedmerpoole, Sutton, Surrey-709

Statham, H. H., 44, Gower-street, W.C.-I 875

Steel, J. S., Strathview, Perth, N.B.-437

Steele, F. H. (Miss), 63, Rowan-rd., Brook-green, W.-1952, 1995, 2008 :

Steggles, R. J., 34, Caversham-road, Camden-road, N.IV.-1714, 1815

Stein, L. (Miss), I6I, Adelaide-road, South Hampstead, I500

Sterry, E. S. (Miss), 3, Bedford-place, Croydon-1464, 1467

Steuart, A. M. G. (Miss), 29, Boulevard des Batignolles, Paris-508

Sterens, J. H., 21, High-park-street, Liverpool-744

Stevenson, J. J., 4, Porchester-gardens, WV.-1753

Stewart, A., 3, Randolph-gardens, Maida-vale, N.W. -623

Stewart, C. E., 6, Melina-place, St. John's-wood, N.W.-I24 
Stewart, K. (Miss), 54, Cotleigh-road, West Hampstead-I 448 Stewart, R., 29, Maddox-street, W.-I 555

Stock, H. J., 454A, Fulham-road, S.W. -528

Stokes, A., I A, Kensington-square, W.-I057

Stokes, L., Prince's-street, Westminster, S.W. -1789

Stoney, T. B., 6A, Stanley Studios, Park-walk, Chelsea-678

Stoppoloni, A. G., I, Upper Cheyne-row, Chelsea, S.W.-653, 754, 912

Stormont, H. G., Ypres Studio, Rye, Sussex, 1212

Stormont, M. (Mrs. H. G.), Ypres Studio, Rye, Sussex-II92

Stott, E., Amberley, Sussex-867

Stratton, A., University College, Liverpool-I 79I

Streatfield, G. E. S., 26, York-place, IV.-1896

Street, K. (Miss), 53, Highbury-park, N.-I336

Stretton, P. E., 40, Dover-street, W. -2 I I, 433, 1047

Strutt, A. E., I43, Darnley-road, Gravesend-1269

Strutt, A. W., Rhosille, Wadhurst, Sussex-2 I, 442, 655, I3 I I

Stuart, C., The Hermitage, Cleve-rd., West Hampstead, N.W.-209,

588

Sutcliffe, L., Sun-buildings, Park-row, Leeds-I 599

Suthers, L., The Cottage, Porlock, Somerset-983

Swain, N., 148, Hailsham-avenue, Streatham-hill, S.W.-760

Swainson, M. (Miss), 2, Southend-villas, Cheltenham-1946

Swan, C.E., 233A, Stanhope-street, N.W. -562

Swingler, J. F., I9, Prebend-gardens, Chiswick-196

Swinstead, G. H., The Studio, 24, Weston-park, Crouch-end, N.-270,

681,787

Sykes, G., 33 \& 34, Estate-buildings, Huddersfield-1339

Symonds, W. R., Cornwall Lodge, Rowan-rd., Brook-green, W.667

Synge, E. M., Eastlands, Weybridge-1557, I559

THORNYCROFT, H., R.A., 2A, Melbury-road, Kensington, W.-

TUKE, H. S., A., Lyndon Lodge, Hanwell, W. $-359,483,1062$

Tait, A. S. (Miss), 99, Burnt-ash-road, Lee-425. 797

Talbot, L. A., c/o J. P. Jacomb-Hood, 26, Tite-street, Chelsea534

Tankerville, The Earl of, Chillingham Castle, Belford, Northumberland-1363, 1364, 1365, 1366

Tanner, H., jun., 19, Haymarket, S.W.-1696

Tapper, W. J., I, Raymond-buildings, Gray's-inn, W.C.-I $\$ 24$ 
Tarver, H. M. (Miss), The Bungalow, Old Bushey, Herts-I499, I 5 I5, 1516, I 522

Taubman, F. M., 66, Glebe-place, Chelsea-I9I5

Tayler, A. C., 30, Sussex Villas, Kensington, W.-592

Taylor, L., I6, Connaught Mansions, Battersea-park, S. W.-I 569

Taylor, L. C., 6r, Broadhurst-gardens, N.W.-75, 916, 938

Teasdale, P. M., 3, Broomfield-road, Headingley, Leeds-II3

Teesdale, K. J. M., The Warren, Cranleigh, Surrey-416

Temple, C. H., Lincoln-hi'l, Iron Bridge, Salop-I859

Temple, R. S., The Lodge, Lammas, Norfolk-65

Tenison, N. (Miss), 215, Uxbridge-road, W.-1640

Terry, A. D. (Miss), 2, Prince's-road, Wimbledon-4I 5

Thaulow, F., 2I, Boulevard Berthier, Paris-365, 608

Thiede, A., 4, Pomona Studios, New King's-rd., Fulham, S. W. -654 Thomas, D. A., I, Harley Studios, Priory-grove, South Kerisington1925

Thomas, P. E. F. (Miss), The Beeches, Tymaston, Haverfordwest$75^{8}$

Thompson, H. R., 6, Parkhill-rcad Studios, Priory-grove, Haverstockhill-I I 33 , I I 34, I I 35

Thompson, I. (Miss), 29, Victoria-avenue, Whitley B yy, near Newcastleon-Tyne-I4I3

Thompson, S., 22, Margaretta-terrace, Chelsea, S. W.-1og8

Thomson, W. H. (Miss), 57, Onslow-square, S.W.-r 383 , 1384, 1385

Thorburn, A., 88, Fell $\sim$ ws-road, South Hampstead, N.W.-II95

Tilney, F. C., Unaleigh, Green-lanes, Winchmore-hill, N.-1573, 1738

Tindall, E., 13, Vernon-road, Woodhouse-lane, Leeds-725

Titcomb, W. H. Y., St. Ives, Cor wall-330

Tizard, K. (Miss), 40, Spring-street, Paddington-1949

Tofano, E., Chelsea Arts Club, Chelsea, S.W. -583

Toft, A., I I, Trafalgar Studios, Manresa-road, Chelsea-I959

Topham, F. W. W., Coneyhurst, Ewhurst, Surrey-6r9

Torromé, F. J., 57, Palace-road, Tulse-hill, S.W. -45I, 590, 687

Towers, S., Bron Avon, Llandudno-junction, North Conway-I227

Townshend, J., Studios, I I2, Prince of Wales-road, N.W.-799

Tree, P., 59, Linden-road, St. Leonard's-on-Sea-1882

Trier, A. (Mrs.), 6, The Terrace, Champion-hill, S.E. -566

Triggs, H. I., Stafford House, Chiswick-1864, I888

Trinnell, H. C., White Cliff, Woldingham, Surrey-1729

Tucker, A., Windermere, Westmorland-I099, I209 
Tucker, T. St. G., 31, Paulton-square, Chelsea, S. IT.-I 50, 522

Turner, A. W., Springfield, Heworth, York-59

Turner, J. (Mrs. H.), 5I, Tavistock-square, W.C.-II5I

Turner, W. L., Hawkshead, North Lancashire-47

Turrell, A. J., I I 7, Alexandra-road, St. John's-wood-1580

Turrell, H., c/o Charles Turrell, Esq., 27, Old Bond-street, WV.I 445,1476

Tweed, J., I4A, Cheyne-row, Chelsea-I944

Tyson, J. H., 14, Chatsworth-avenue, Liscard, Cheshire-132S

Underwood, E. S., 3, Queen-street, Cheapside, E.C. -1857

Urquhart, W. J., 237, King's-road, Chelsea-I622

Urwick, W., 3, Hill-road, St. John's-wood, N.W.-299, 878

Vander Weyden, H., Montreuil-sur-Mer, France-367, 733, 796

Van Ruith, H., I8, Holland-park-road, IV. $-287,362$

Vedder, S. H., 7, The Mall, Parkhill-road, Haverstock-hill, N. IT.-

I 66

Veness, A. M. (Miss), 28, Malpas-road, Brockley, S.E.- 22 I

Ventnor, A., 5, Carnarvon-road, Norwich-794

Verey, A., 54, Cavendish-road, Kilburn-1323

Verner, F. A., 39, Palace-terrace, Fulham-4 I I

Vigor, C., I 5, Bolton Studios, Redcliffe-road, S.W.-88, 1005, 1018

Vokes, A. E., Goodyear-chambers, Northampton-498

Von Glehn, W. G., 58, Glebe-place, Chelsea, S. W. -542 .

WATERHOUSE, A., R.A., 20, New Cavendish-street, Portland-pl., W. -599

WATEKHOUSE, J. W., R.A., 6, Primrose-hill Studios, Regent'spark, N.W. -I 55

WATTS, G. F., R.A., Little Holland House, Kensington, W.-207

WELLS, H. T., R.A., Thorpe Lodge, Campden-hill, WV.-30, 225, $278,384,1598$

WOODS, H., R.A., c/o Luke Fildes, Esq., R.A., I I, Melbury-road, Kensington, W.- I I 6,153

WATERLOW, E. A., A., I, Maresfield-gardens, Fitzjohn's-avenue, N.W. -I 2, I93, 672

WEBB, A., A., I9, Queen Anne's-gate, Westminster, S. W.-IS66 WYLLIE, W. L., A., Hoo Lodge, Hoo Saint Werburgh, Rochester275

Wade, G. E., The Avenue, 76, Fulham-road, S.W.-1927, I977 
Waite, E. W., Abinger Hammer, Dorking-328

Waite, H., I4, Lee-park, Blackheath, S.E.-I37

Waite, T., 7, Maitland-park-villas, N.W.-829

Wakley, H. M., Albion-chambers, Adams-street, W.C.-1877

Walbourn, E., Holmdale, Chingford, Essex -806

Walenn, F. D., The Studio, I5, Avenue-road, St. John's-wood, N.W.

-887, I027

Walker, A. E. (Miss), I4A, Cheyne-row, Chelsea-123

Walker, A. G., 5, Cedars Studios, Glebe-place, Chelsea-2049, 2050

Walker, F. H., Oakdene, East Burnham-common, near Slough-2I 7

Walker, F. S., 58, North-hill, Highgate-932, I 574

Walker, J. H., jun., I 7, North Audley-st., Grosvenor-sq., W.-2009

Walker, W. (Miss), 4, Torrington-park, North Finchley, N.W.-1362

Wallace, J., 39, Bramerton-street, Chelsea-925

Waller, M. L. (Mrs. S. E.), 58, Circus-road, St. John's-wood, N.W.408, 484

Waller, S. E., 3, Wychcombe Studios, Haverstock-hill, N.W.-950

Walton, F., Holmbury St. Mary, Dorking-378, 778, 909, I I4I

Wane, R., I3, Kinglake-road, Egremont, Cheshire-1038, I1 89

Ward, A., 6, Pembroke Studios, Pembroke-gardens, Kensington, W.

$-335$

Ward, C. D., 237, King's-road, Chelsea, S.W.-739

Ward, G. W., 30, Mosley-street, Newcastle-on-Tyne-1686

Ward, Herbert, I, Woronzow-road Studios, St. John's-wood, N.W.

-399, I957

Ward, H., 8, Bank-buildings, Hastings-I 786, I 854

Ward, W. H., 28, Theobald's-road, W.C.-I 770 , I903

Wardle, A., 34, Alma-square, St. John's-wood, N.W.-26, 329,

I 163

Warn, B., I4, Meadow Studios, Bushey, Herts-1435, 1520

Warne, A. C. (Miss), I32, Kyverdale-road, Stamford-hill-321

Watson, C. J., 5, Wentworth Studios, Manresa-rd., Chelsea-I 295, I 535

Watson, G. S., 2, Pembroke Studios, Pembroke-gardens, Kensington572,1046

Watson, H., 18, Kensington-court-place, Kensington, W.-57 I, 801,

825,1066

Watson, J., 5, Nesham-street, Newcastle-on-Tyne-965

Watson, P. H., 4, Adam-street, Adelphi, W.C.-1720, 1838

Watson, T. L., I66, Bath-street, Glasgow-1898

Watts, J. T., 34, Lidderdale-road, Sefton-park, Liverpool-1233

Watts, L. M. (Mrs. J. T.), 34, Lidderdale-road, Sefton-park, Liverpool 
Wauters, E., 57, Rue Ampère, Paris-458, 1070

Way, C., Bruce-buildings, Newcastle-on-Tyne-I I4

Way, F. (Mrs. A. Thacker), 4, Gwendwr-road, West Kensington, W.

$-1374,1403$

Wear, M. (Miss), I A, Lennard-place, Circus-road, N. W.-I495

Weaver, E. (Miss), I 7, Nottingham-place, IV.-I I60

Weaver, H. P., 46, Belsize-road, S. Hampstead-I3I4

Webb, J. C., I I I, Clifton-hill, St. John's-wood, N.W.-r6r4, r668

Webb, W. E., 30, Exchange-bldgs., St. Mary's-gate, Manchester-

830

Webley, S., 68, Kelmscott-road, Clapham-junction-I603, I657

Weedon, A. W., I93, Portsdown-road, IV.-III3

Wehrschmidt, D. A., 6A, Holbein Place, S. W.--1079

Weir, E. D. (Miss), 58, Trumbull-street, New Haven, U.S.A.-

\section{4}

Weiss, J., Houghton, Arundel, Sussex-372, 633, I020

Welby, R. (Miss), 23, Greycoat-gardens, Victoria-street, S. W.-966

West, J. W., The Sundial, Northwood, Middlesex-250, I610, 1646

Western, C., 3, Terrett's-place, Upper-street, N.-919

Wetenhall, E. B., 27, Fitzroy-street, Fitzroy-square-I 744

Wetherbee, G., I3, Cannon-place, Hampstead, N.IV.-266, 313

Whall, C. WV., 19, Shaftesbury-road, Ravenscourt-park-1844

Wheelwright, R., I8, Grosvenor-road, Watford-95, 257, 683

Whellock, R. P., 45, Finsbury-pavement, E.C.-1699

White, A. C., 93, Clifton-hill, N.W.-1932, I94I

White, E. R., 36, Barclay-road, Walham-green-I264

White, F. (Miss), 8, Bolton Studios, South Kensington-1367, 1368 I 369, I 389

White, I. (Miss), 2, Kensington Studios, Kelso-place-245

White, J., Branscombe, Axminster, East Devon - 520, 663

White, S. W., 32, Great Ormond-street, W.C.-I69

Whitehead, E. (Miss), 5, Lansdowne-terrace, Leamington Spa-779, So2 Whiteley, J. WV., Staveley via Leeds-310

Whiteside, R. C. (Miss), 13, Chaucer Mansions, Queen's-club-gardens, IV.-I 144

Whiting, A. (Miss), Cromwell-bdgs., Melbourne, Australia-r478, 1490

Whiting, F., Studio, 22, Park-village-east, N.W.-1620

Whitley, W. T., 78, Alexandra-road, St. John's-wood, N.W.-497

Wild, F. P., The Studio, Marlow, Bucks-I 79, 928

Wilkinson, M. I. (Miss), Limnersholme, Old Bushey, Herts-1 526 
Williams, A., Studio, 8, Holland-villas-road, Kensington, S.W.1440

Williams, L. G. (Miss), 4, The Studios, Holland-park-road, W.1928, 1940, 1961

Williams, T., Art Club Studios, Blackheath, S.E.-63, 247, 295, 400,947

Williamson, F., Quex Lodge, West-end-lane, N.W.-I266

Willink and Thicknesse (Messrs.), Liverpool-1748

Willis, E. M. (Miss), 3I, Leinster-terrace, Hyde-park, W.-109I

Willis, F., Glenavon, Frances-road, Windsor-I666

Willson, E. D. (Miss), Ballamona, Headingley, Leeds-I24I

Willson, J. J., Ballamona, Headingley, Leeds-I I9I

Wilmshurst, G. C., 70, Adelaide-road, N.W.-70

Wilson, C. E., The Studio, Milford-heath, Godalming-I 140

Wilson, G. W. I., 3A, The Avenue, 76, Fulham-road-2022

Wilson, P., Gloucester House, Sudbury, Harrow-1530, I660

Wimbush, J. L., 8, Fitzroy-street, Fitzroy-square, W. -884

Wimperis, J. T., and Arber (Messrs.), 25, Sackville-street, W.1767

Winkfield, F. A., 59, Britannia-road, Fulham, S.W.-407, 531

Wirgman, T. B., 24, Dawson-place, W.-664, 949

Witherby, H. F., I, Eliot-place, Blackheath-422, 705

Wood, C. M. (Mrs. R. H. Wright), 2, Harcourt-buildings, Temple, E.C. $-223,242,742,763,822$

Wood, E., 78, Cross-street, Manchester-I752, I774

Wood, F. D., Fontana Studios, 27, Glebe-place, Chelsea-1926,

1934, 1953

Wood, J. B., Woodbridge, Suffolk-859

Wood, W. T., Putney-heath, Putney, S.W.- -808

Woodroffe, P., 45, Rowan-road, Brook-green, W.-1582

Woodville, R. C., Io7, Queen's-gate, S.W.-627

Woodward, A. B. (Miss), I 29, Beaufort-street, Chelsea-1679

Woolhouse, E. M. (Miss), Tamworth, Staffordshire-56I

Wornum, R. S., 26, Bedford-square, W.C.-1878

Worsfold, E. M., Florence Villas, Feltham, Middlesex-I 5 I2

Worsfold, M. B. (Miss), 20A, Campden-hill-gardens, W.-I431,

1480

Wright, E. (Mrs. A. Barclay), 2, Harrington-gardens, S.W. -530

Wright, G., 26, Regent's-park-terrace, Hyde-park, Leeds- $-652,818$

Wright, G. S., 33, St. German's-road, Forest-hill, S.E.-990

Wright, L. F. (Miss), The Willows, Harlesden-I652

Wyllie, C. W., 8^, Elm-tree-road, St. John's-wood-40I 
slesias, V. P., I4, Grove-end-road, N.W. $-42,541,675$

oung, A. S., 30, Trafalgar-square, Chelsea-1969

loung M. (Miss), 9, The Avenue, 76, Fulham-road, S. W. -540

Young, W., 6, Lancaster-place, Strand, W.C.-I909

Zink, G. F., 34, Princess-roąd, Kilburn-park, N. W.-I414

The following Academicians and Associates do not exhibit this year.

AITCHISON, G., R.A., I 5o, Harley-street, W.

ARMSTEAD, H. H., R.A., 52, Circus-road, St. John's-wood, N.W. BODLEY, G. F., A., 4I, Gloucester-place, Portman-square.

FAED, T., R.A., 24A, Cavendish-road, St. John's-wood, N.W.

HORSLEY, J. C., R.A., I, High-row, Kensington, W.

NICOL, E., $A$., The Dell, Feltham, Middlesex.

PICKERSGILL, F. R., R.A., The Towers, Yarmouth, Isle of Wight.

ST ACPOOLE, F., A., I, Nassau-gardens, Church-road, Barnes, Surrey. YEAMES, W. F., R.A., 4, Campbell-road, Hanwell, IV. 


360 -

$\infty$

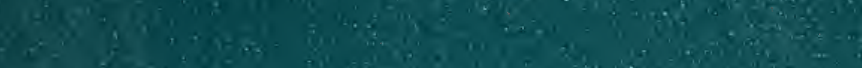

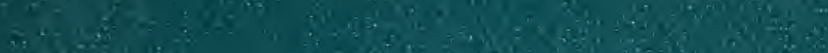

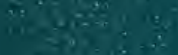

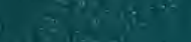

$\ln ^{2} x^{2}$ and

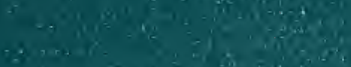

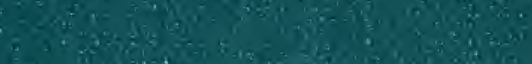

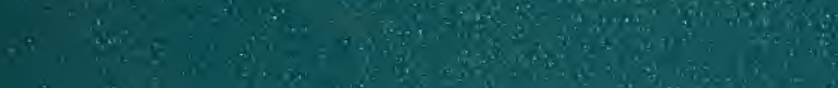
and

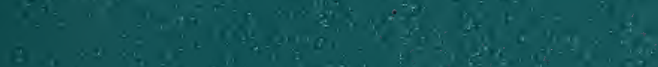

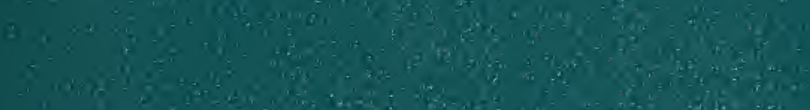

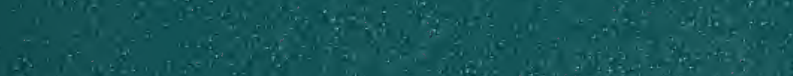

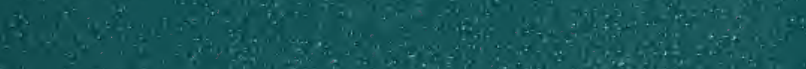

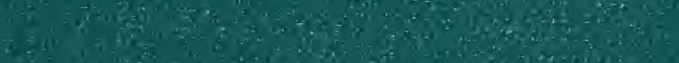

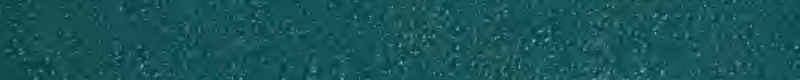

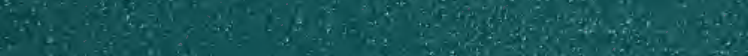
F.

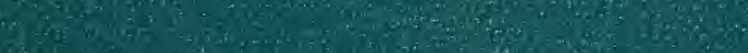
2.

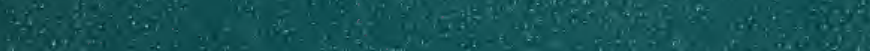

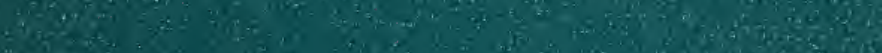

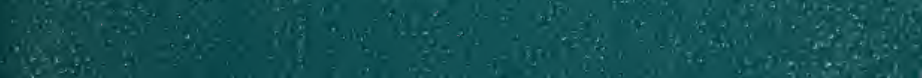


SMITHSONIAN INSTITUTION LIBRARIES 